Article

\title{
A Phytosociological Study on Andean Rainforests of Peru, and a Comparison with the Surrounding Countries
}

\author{
Antonio Galán-de-Mera ${ }^{1}$ * $\mathbb{1}$, José Campos-de-la-Cruz ${ }^{2}$, Eliana Linares-Perea ${ }^{3}$, \\ Juan Montoya-Quino $^{4}$, Iván Torres-Marquina ${ }^{5}$ (D) and José Alfredo Vicente-Orellana ${ }^{1}$ \\ 1 Laboratory of Botany, San Pablo-CEU University, CEU Universities, Boadilla del Monte, \\ 28660 Madrid, Spain; avicore@ceu.es \\ 2 Natural History Museum, Major National University of San Marcos, 15046 Lima, Peru; jocamde@gmail.com \\ 3 Phytogeographical Studies of Peru Foundation, Paucarpata, 04007 Arequipa, Peru; elialinper@gmail.com \\ 4 CPUN Herbarium, National University of Cajamarca, 06003 Cajamarca, Peru; juanfmq9@gmail.com \\ 5 Baños del Inca, 06004 Cajamarca, Peru; itorresm@hotmail.com \\ * Correspondence: agalmer@ceu.es
}

Received: 25 October 2020; Accepted: 24 November 2020; Published: 26 November 2020

check for updates

\begin{abstract}
This work is a phytosociological approach to the montane rainforests of Peru with the aim of advancing on the diversity of plant communities, which we had already begun in previous research. From 364 phytosociological plots and 3389 species of the South American tropics, we have developed a cluster, using the Sørensen index, to know the similarities between the forests and their parallelism with bioclimatic conditions. After studying the existence of characteristic groups of the Peruvian forests, we have established different communities and phytosociological units for Peru. As a result, we have described seven associations, within three new alliances, which are gathered in the new order Saurauio peruvianae-Condaminetalia corymbosae of the new class Morello pubescentis-Myrsinetea coriaceae. In addition, two associations have been described within the class Pruno rigidae-Oreopanacetea floribundae (mesotropical laurel-like forests), and three for the class Alnetea acuminatae (alder forests and palm groves). The humid forests of Peru are closer to those of Ecuador and to those of the set formed by the three Colombian mountain ranges than to those of Bolivia and Argentina, due to the common flora these share with areas of Paraguay and even of the Parana River region.
\end{abstract}

Keywords: rainforests; phytosociology; syntaxonomy; Peru; South America

\section{Introduction}

Tropical montane rainforests are located worldwide in areas where east-west winds (Trade Winds) blow against the mountains [1,2], establishing well-defined vegetation belts that depend on rainfall and humidity condensation at medium elevations.

In South America, winds from Amazonia push the evapotranspiration humidity to the Andean forests. The decrease in temperatures causes condensation of humidity, and consequently downpours, particularly between 1000 and $3500 \mathrm{~m}$, producing forests of enormous diversity [3,4] between Venezuela and NW Argentina. They depend on rainfall oscillation of between 500 and $600 \mathrm{~mm}$ above $3500 \mathrm{~m}$ and more than $5000 \mathrm{~mm}$ at $600 \mathrm{~m}$ above sea level [5-7].

In the Peruvian Andes, some authors distinguish between mountain and brow forests [8-11]: the mountain extending between 1800 and $3400 \mathrm{~m}$, where genera such as Cecropia, Cinchona, Luehea, and Ochroma are abundant, and are replaced by the mountain brow between 3400 and 3600 (3900) m above sea level, with Ericaceae, Polylepis, and Weinmannia. The most recent authors have established a more precise division [12-14]: mountain rainforests, between 600 and 650 and 1300-1400 m, where trees reach $35 \mathrm{~m}$ in height, palms abound but not Mauritia, and wild cocoa appears; cloud forests, between 1300 
and $1400 \mathrm{~m}$ and $2500-2550 \mathrm{~m}$, trees up to $20 \mathrm{~m}$ with tree ferns, where the most common trees belong to the genera Brunellia, Ceroxylon, Hieronyma, Meliosma, Miconia, Myrcianthes, Saurauia, and Sapium, and Alnus acuminata Kunth especially dominates along watercourses, and dwarf forests (mountain brow), between 2500 and 2550 and 3000-3800 m, up to 5-20 m of tree canopy, where Axinaea, Cervantesia, Columellia, Drimys, Escallonia, Gaiadendron, Hedyosmum, Ilex, Miconia, Myrsine, Styrax, Symplocos, and Vallea are the most common genera. Understories consist of scandent bamboos, mainly of the genus Chusquea, with vines of Clematis, Mutisia, Jungia, and Passiflora. The higher zones have forests of Buddleja, Gynoxys, and Polylepis. In general, mountain forests reach $4700 \mathrm{~m}$ in Bolivia, and 3800-4200 $\mathrm{m}$ from southern Peru to Venezuela. This division is very close to that of Malizia et al. [15] in Argentina, which distinguishes four vegetation belts: tropical premontane forest plots ( $<1500 \mathrm{~m}$ above sea level) associated with Clarisia biflora Ruiz \& Pav., Heliocarpus americanus L., and Solanum ochrophyllum Van Heurck \& Müll. Arg., while Nectandra subbullata Rohwer and Piper obliquum Ruiz \& Pav. are related to tropical lower montane forest plots (i.e., 1500 to $2700 \mathrm{~m}$ above sea level). Cornus peruviana J.F.Macbr., Hedyosmum scabrum (Ruiz \& Pav.) Solms, Hesperomeles ferruginea Lindl., Licaria applanata van der Werff, Myrcianthes rhopaloides (Kunth) McVaugh, Myrsine dependens (Ruiz \& Pav.) Spreng., and Podocarpus oleifolius D.Don are associated with tropical upper forest plots (i.e., 2700 to $3500 \mathrm{~m}$ above sea level), while Polylepis pauta is grouped with plots above the upper forest line (>3500 $\mathrm{m}$ above sea level).

However, the montane rainforest also extends along the Pacific slope of the Andes between 2400 and $3800 \mathrm{~m}$ above sea level between Venezuela and northern Peru, with some relicts in the center, due to disturbances caused by the warm tropical current [16-18].

Among the 40,000 plant species recognized in the Andes, about 30,000 correspond to the mountain forests [19], and only about 5000 to the mountain forests of central Peru [20]. This enormous diversity is connected to the major uplift of the Central Andes during the Paleogene (65 to $34 \mathrm{Ma}$ ) and subsequent plate collisions that intensified mountain building in the Northern Andes (23 Ma) [21]. However, the Andes reached their modern elevation during the late-mid-Miocene ( 12 Ma) and early Pliocene ( 4.5 Ma) [22,23], which gave rise to the ecosystems we know today. This last period also saw the culmination of the formation of the Central American corridor [24], which led to the northward expansion of the Humboldt sea current, strengthening the aridity of western Peru and causing the disappearance of most of the settled forest masses. In addition, this phenomenon enabled the arrival of Laurasian taxa from families such as Aquifoliaceae, Berberidaceae, Betulaceae, Cornaceae, Fagaceae, and Rosaceae, which we find in the middle and upper levels of the Andes (bioclimatic meso-orotropical belts) linked to wind pollination on many occasions. Nevertheless, many of the families with tubuliform flowers which originated in Gondwana (i.e., Acanthaceae, Apocynaceae, Bignoniaceae, Bromeliaceae, Ericaceae, Gesneriaceae, Musaceae, Palmae) are more frequently found in the lower levels (thermo-infratropical belts), evidencing co-evolution with hummingbirds, nectar-feeding bats, and specialized birds. Podocarpaceae are relicts which originated in the South of the Andes, and which possibly arrived in the Pleistocene [25], forming meso-supratropical communities in cold and humid places, such as Weinmannia. The presence of Laurasian taxa such as Alnus, Berberis, Cornus, Ilex, Quercus (Colombia), and Rubus characterize the Neotropical montane forests [26], and separate them from those of Amazonia [11,12,27]. On the other hand, other authors include them as a biogeographical unit within Amazonia [5,28,29].

Although the phytosociological method of Braun-Blanquet [30] has been applied in numerous areas of the world (i.e., South Africa, Lesotho and Swaziland [31], American Arctic Zone [32], Western North America [33], Taiwan [34], Argentina [35], and the Caribbean region [36]), few phytosociological works on mountain rainforests in the extensive territory of South America have been published. Some examples are those of Venezuela [37-39], Colombia [40-44], Ecuador [45,46], Bolivia [47], and Argentina [48-50]. In Peru, only a few plots have been studied in some areas of the North [18]. Here, we present plots and plant communities of humid mountain forests throughout the country, comparing them to the adjacent territories, and carry out a syntaxonomical hierarchy assay, in addition to the published papers of the western arid desert [51-53] and the highlands [18,54]. 


\section{Results}

\subsection{Relationships among South American Montane Rainforests}

As a result of statistical analysis taking into consideration all the forests presented in the Supplementary Tables S1-S3, a dendrogram was generated (Figure 1). Here, we can distinguish 15 main groups: Groups $\mathrm{A}$ and $\mathrm{O}$ are greatly separated because they represent two very different forests from the Peruvian Amazonian lowlands: Group A containing Euterpe catinga Wallace (Pachiro brevipedis-Euterpetum catingae Galán de Mera 2001), and Group O containing Mauritia flexuosa L.f. (Oenocarpo maporae-Mauritietum flexuosae Galán de Mera 1996). Group B are the subhumid and humid meso-supratropical forests of Bolivia, and they are closely related to those of Argentina (C), because they contain common plants, such as Alnus acuminata, Baccharis latifolia (Ruiz \& Pav.) Pers., Dolichandra unguis-cati (L.) L.G. Lohmann, Duranta serratifolia (Griseb.) Kuntze, Podocarpus parlatorei Pilg., Rubus bogotensis Kunth, and Rubus boliviensis Focke.

Group D are the thermotropical subhumid and humid forests of Bolivia, where we can also differentiate common taxa with that of Argentina such as Juglans australis Griseb., Myrcianthes mato (Griseb.) McVaugh, Ocotea porphyria (Griseb.) van der Werff, Patagonula americana L., Schinopsis marginata Engl., and Siphoneugena occidentalis D. Legrand.

Between groups E to I, the montane rainforests of Colombia are found: Group E are the thermoinfratropical hyperhumid and ultra-hyperhumid forests of the western Andean mountain range with Cyathea pungens (Willd.) Domin, Ficus hartwegii Miq., Jacaranda hesperia Dugand, Nectandra pichurim (Kunth) Mez, Ocotea ira Mez \& Pittier, and Weinmannia balbisiana Kunth. However, group F are especially mesotropical hyperhumid and ultra-hyperhumid forests in these western mountains where distinctive plants change to Clethra fagifolia Kunth, Clusia clusioides (Griseb.) D'Arcy, Hedyosmum bonplandianum Kunth, Prunus integrifolia (Sudw.) Sarg., Quercus humboldtii Bonpl., Schefflera ferruginea (Willd. ex Schult.) Harms, or Weinmannia mariquitae Szyszyl. The column 15COLori (Drimys granadensis L.f.-Weinmannia fagaroides Kunth from the Eastern Andean mountain range) is within group F because we find plant communities containing plants common with group F, such as Dioscorea coriacea Humb. \& Bonpl. ex Willd., Drimys granadensis, Myrsine dependens, and Sphyrospermum cordifolium Benth. In the same way, 35COLcen (Weinmannia magnifolia Cuatrec.-Quercus humboldtii from the Central Andean mountain range) also contains plants common with the rest of the communities of group F, such as Clusia multiflora Kunth, Escallonia myrtilloides L.f., Gaiadendron punctatum (Ruiz \& Pav.) G. Don, Miconia latifolia (D. Don) Naudin, Palicourea angustifolia Kunth, or Uncinia hamata (Sw.) Urb. Group G also includes three ultra-hyperhumid mesotropical plant communities from the Central Andean mountain range of Colombia, where there are species common with the occidental territories (Alansmia lanigera (Desv.) Moguel \& M. Kessler, Begonia umbellata Kunth, Clusia multiflora, Lophosoria quadripinnata (J.F. Gmel.) C. Chr., Miconia psychrophila Naudin, and Uncinia hamata). Group H are mostly the branches belonging to the Eastern Andean mountain range of Colombia, where we can find some characteristic plants such as Anthurium crassinervium (Jacq.) Schott, Cassia moschata Kunth, Cordia polycephala (Lam.) I.M. Johnst., Machaerium capote Dugand, or Thibaudia rigidiflora A.C. Sm. for humid to ultra-hyperhumid infra- or thermo-tropical bioclimatic belts. In contrast, Ceroxylon alpinum Bonpl. ex DC.-Calatola costaricensis Standl. and Clusia elliptica Kunth-Ilex pernervata Cuatrec. are located in the mesotropical subhumid bioclimatic belt.

Close to group $\mathrm{H}$ is group $\mathrm{I}$, with columns from Central Colombia and Ecuador. The plant communities from Colombia are especially within hyperhumid and ultra-hyperhumid meso-supratropical bioclimatic belts. Here, we can again find species such as Quercus humboldtii, Weinmannia mariquitae, or Hedyosmum humboldtianum, but with characteristics such as Chusquea spectabilis L.G. Clark, Clusia minor L., Polylepis quadrijuga Bitter, or Weinmannia reticulata Ruiz \& Pav. Humid supra-mesotropical branches of Ecuador reflect species common with Central Colombia such as Drimys granadensis, Gaiadendron punctatum, Gaultheria myrsinoides Kunth, Miconia salicifolia (Bonpl. ex Naudin) Naudin, Oreopanax incisus (Willd. ex Schult.) Decne. \& Planch., Vallea stipularis L.f., or Weinmannia pubescens Kunth. 


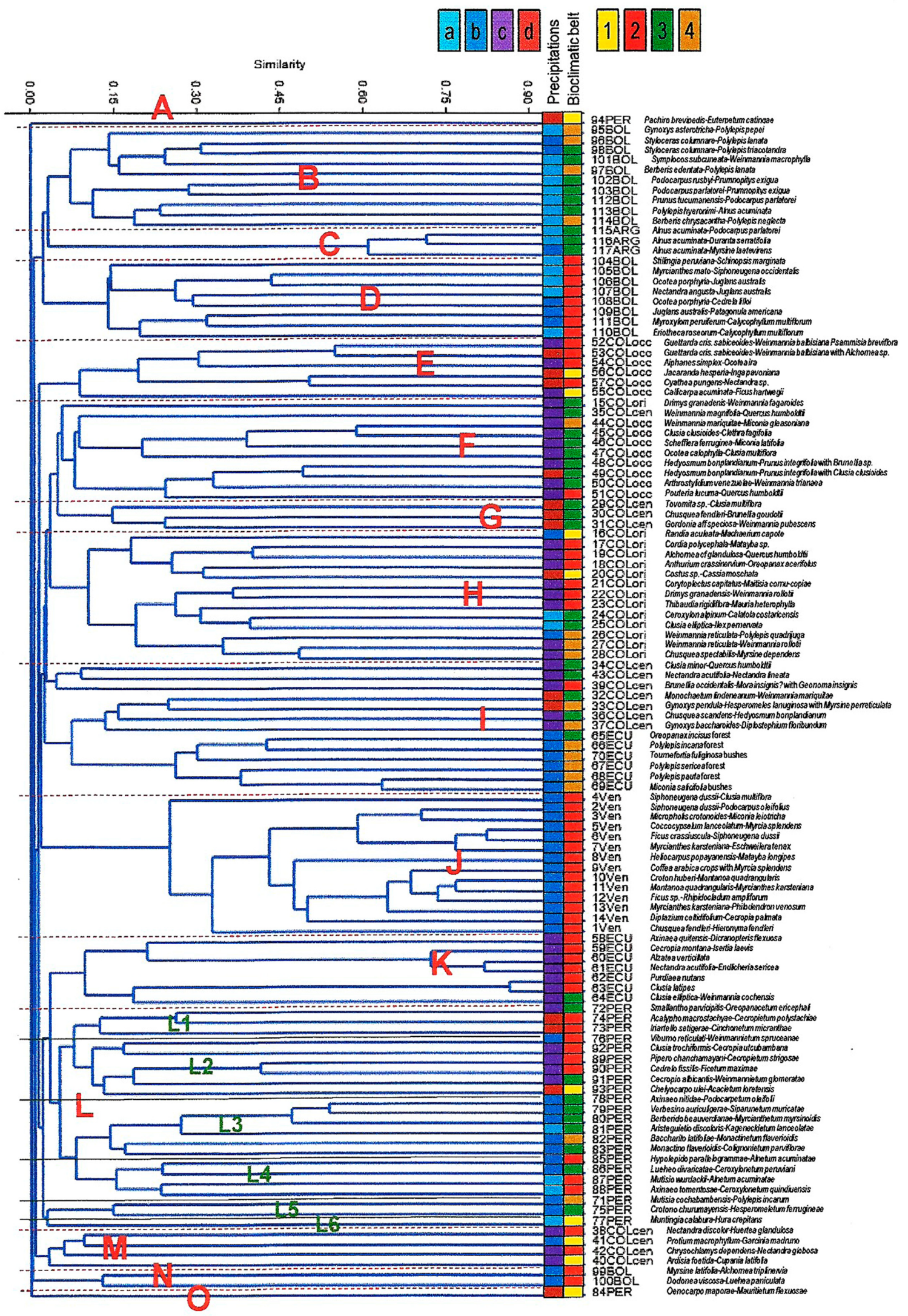

Figure 1. Cluster analysis with the unweighted pair-group average (UPGMA) applying the Sørensen index. Bioclimatic belts: 1: infratropical, 2: thermotropical, 3: mesotropical, 4: supratropical. Precipitation intervals: a: subhumid, b: humid, c: hyperhumid, d: ultra-hyperhumid. Capital letters are the groups detected in the dendrogram and explained in the text. 
Group J belongs to the Venezuelan columns with a humid thermotropical bioclimate where only widely distributed plants, such as Anthurium nymphaeifolium K. Koch \& C.D. Bouché, Blechnum occidentale L., Clusia multiflora, Myrcia splendens (Sw.) DC., Myrsine coriacea (Sw.) R. Br. ex Roem. \& Schult., or Podocarpus oleifolius are common with Colombia, Ecuador, and Peru.

Furthermore, group K are hyperhumid thermo- and mesotropical plant communities of Ecuador, where there are more plants common with Peru than in the case of group I. These include Baccharis genistelloides (Lam.) Pers., Calceolaria calycina Benth., Cecropia angustifolia Trécul, Cyathea lechleri Mett., Gaultheria reticulata Kunth, Piper barbatum Kunth, Geonoma orbignyana Mart., Podocarpus oleifolius, or Rubus boliviensis.

Group L represents the forests studied throughout Peru. Here, we can distinguish several subgroups: L1 are hyperhumid and ultra-hyperhumid thermo-mesotropical forests from Southern Peru, L2 are forests ranging from humid to hyperhumid and thermo- to mesotropical from Northern and Central Peru, L3 encompasses the subhumid to humid meso- and supratropical forests and shrub formations from Northern Peru, where Oreopanax eriocephalus Harms and Baccharis latifolia are respectively constant, subgroup L4 are the Andean alder forests that grow on hydromorphic soils with constant moisture, although they share a bioclimate that ranges from subhumid to humid and thermoand mesotropical, L5 are high Andean hyperhumid meso- and supratropical forests from the South of Peru with Polylepis incarum (Bitter) M. Kessler \& Schmidt-Leb. and Hesperomeles ferruginea, and finally, branch L6 is a unique plot containing Muntingia calabura L. and Hura crepitans L., a flooding forest within a subhumid infratropical bioclimate.

With group M, we return to the forests of the central Andean mountain range of Colombia, but here, there are the infra- and thermotropical humid and hyperhumid forests. These are located next to those of Peru due to common species such as Disterigma acuminatum (Kunth) Nied., Dryopteris patula (Sw.) Underw., Miconia aggregata Gleason, Geonoma orbignyana, Hedyosmum racemosum (Ruiz \& Pav.) G. Don, Piper arboreum Aubl., Serpocaulon fraxinifolium (Jacq.) A.R. Sm., Styloceras laurifolium (Willd.) Kunth, and Urera baccifera (L.) Gaudich. ex Wedd. The same is applicable to the humid thermotropical plant communities Myrsine latifolia (Ruiz \& Pav.) Spreng.-Alchornea triplinervia (Spreng.) Müll. Arg., and Dodonaea viscosa (L.) Jacq.-Luehea paniculata Mart. from Bolivia (group N), with species such as Cedrela fissilis Vell., Morella pubescens (Humb. \& Bonpl. ex Willd.) Wilbur, Myrsine coriacea, Myrsine latifolia, and Saurauia peruviana Buscal. also present in Peru. Finally, group O is the Oenocarpo maporae-Mauritietum flexuosae association of palms from the ultra-hyperhumid infratropical Amazonian lowlands.

Using the Sørensen coefficient, a numerical similarity analysis of all forests for each country is presented in Table 1. Under each country name, the number of plots and their alpha diversity are presented.

Table 1. Similarity analysis of the montane rainforest per country according to the Sørensen coefficient.

\begin{tabular}{|c|c|c|c|c|c|c|c|c|}
\hline Plots; $\alpha$ Diversity & $\begin{array}{c}\text { VEN } \\
14 ; 226\end{array}$ & $\begin{array}{l}\text { COLori } \\
39 ; 321\end{array}$ & $\begin{array}{c}\text { COLcen } \\
18 ; 821\end{array}$ & $\begin{array}{c}\text { COLocc } \\
39 ; 550\end{array}$ & $\begin{array}{c}\text { ECU } \\
103 ; 819\end{array}$ & $\begin{array}{c}\text { PERU } \\
106 ; 791\end{array}$ & $\begin{array}{c}\text { BOL } \\
24 ; 334\end{array}$ & $\begin{array}{l}\text { ARG } \\
21 ; 89\end{array}$ \\
\hline VEN & 1 & 0.04753199 & 0.04011461 & 0.05412371 & 0.04784689 & 0.02359882 & 0.01403509 & 0 \\
\hline COLcen & 0.04011461 & 0.08581436 & 1 & 0.11232677 & 0.11097561 & 0.05086849 & 0.01545064 & 0.01098901 \\
\hline COLocc & 0.05412371 & 0.11710677 & 0.11232677 & 1 & 0.08473338 & 0.05965697 & 0.01342282 & 0.00625978 \\
\hline ECU & 0.04784689 & 0.09649123 & 0.11097561 & 0.08473338 & 1 & 0.1378882 & 0.04127257 & 0.02863436 \\
\hline ARG & 0 & 0.0097561 & 0.01098901 & 0.00625978 & 0.02863436 & 0.025 & 0.07852194 & 1 \\
\hline
\end{tabular}

VEN: Venezuela, COLori: Eastern mountain range of Colombia, COLcen: Central mountain range of Colombia, COLocc: Western mountain range of Colombia, ECU: Ecuador, BOL: Bolivia, ARG: Argentina.

Here, we can note that there is a shorter distance between the flora of the forests of Ecuador, Bolivia, and the western Colombian mountain range. However, the Venezuelan and Argentinean forests are at a greater distance, while the forests of Bolivia and Argentina are closer. In general, 
Peruvian forests are more similar to those of Ecuador and the three Colombian mountain ranges than Bolivian forests, because the latter have elements in common with Paraguay and the Parana region.

\subsection{Phytosociological Study in Peru}

Phytosociological results for the groups are shown in Appendix A (Table A1), which match those in the dendrogram (Figure 1).

\subsubsection{Describing the New Associations and Plant Communities}

Mutisia cochabambensis Hieron.-Polylepis incarum community

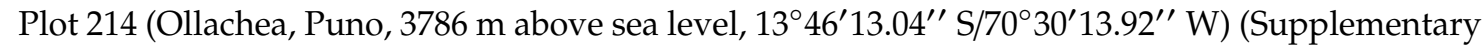
Table S2). Diagnostic species: Citharexylum dentatum D. Don, Elaphoglossum engelii (H. Karst.) Christ, Gaultheria vaccinioides Griseb. ex Wedd., Mutisia cochabambensis, and Polylepis incarum.

Forest dominated by Polylepis incarum, humid supratropical, on rocky and stony areas, with a $40 \%$ slope and an average tree canopy of $10 \mathrm{~m}$, spreading through the south of Peru.

Smallantho parvicipitis-Oreopanacetum eriocephali ass. nov.

Holotypus: Appendix A Table A2; Plot 215, Supplementary Table S2. Diagnostic species: Begonia bracteosa A. DC., Canna iridiflora Ruiz \& Pav., Croton regelianus Müll. Arg., Fuchsia boliviana Carrière, Melica scabra Kunth, Miconia aff. adinantha Wurdack, Pennisetum latifolium Spreng., Phenax angustifolius (Kunth) Wedd., Rubus boliviensis, Sambucus peruviana Kunth, Smallanthus parviceps (S.F. Blake) H. Rob., and Solanum aphyodendron S. Knapp.

Hyperhumid mesotropical forests, with Oreopanax eriocephalus, installed on a steep slope (60\%) and with a forest canopy of about $10 \mathrm{~m}$, on deep sandy soils at the surface, susceptible to strong erosion. We have also studied this association in the San Gaban valley in southern Peru.

Iriartello setigerae-Cinchonetum micranthae ass. nov.

Holotypus: Appendix A Table A2; Plot 221, Supplementary Table S2. Diagnostic species: Aphelandra aurantiaca (Scheidw.) Lindl., Cinchona micrantha Ruiz \& Pav., Cyathea subincisa (Kunze) Domin, Dieffenbachia humilis Poepp., Heliconia hirsuta L.f., Iriartella setigera (Mart.) H. Wendl., Miconia lourteigiana Wurdack, Philodendron rudgeanum Schott, Ruagea insignis (C. DC.) T.D. Penn., and Smilax purhampuy Ruiz.

Lower thermotropical ultra-hyperhumid forests very rich in Peruvian bark trees, with rainfall over $5000 \mathrm{~mm}$. They are located in soft reliefs on clayey soils with a slope between $0 \%$ and $50 \%$. The tree canopy is up to $30 \mathrm{~m}$. They are spread throughout the South of Peru.

Acalypho macrostachyae-Cecropietum polystachyae ass. nov.

Holotypus: Appendix A Table A2; Plot 228, Supplementary Table S2. Diagnostic species: Acalypha macrostachya Jacq., Cecropia polystachya Trécul, and Maranta arundinacea L.

Upper thermotropical ultra-hyperhumid forests from Southern Peru, where rainfall reaches $3600 \mathrm{~m}$. They are located in flat areas, but also on slopes of up to $70 \%$ on soils rich in clay, reaching a forest canopy of up to $30 \mathrm{~m}$, where Cecropia polystachya becomes dominant.

Crotono churumayensis-Hesperomeletum ferrugineae ass. nov.

Holotypus: Appendix A Table A2; Plot 234, Supplementary Table S2. Diagnostic species: Adiantum digitatum Hook., Baccharis genistelloides, Croton churumayensis Croizat, Cuphea cordata Ruiz \& Pav., Gaultheria reticulata, Miconia alpina Cogn., Senna birostris (Vogel) H.S. Irwin \& Barneby, and Tagetes elliptica Sm.

Humid mesotropical forests with a tree canopy of about $8 \mathrm{~m}$, from the south of Peru, that sit on ranker-type soils, stony on the surface, but with scant slope. 
Viburno reticulati-Weinmannietum spruceanae ass. nov.

Holotypus: Appendix A Table A2; Plot 238, Supplementary Table S2. Diagnostic species: Anthurium hamiltonii Croat \& Ligán, Clusia crenata Cuatrec., Gleichenella pectinata (Willd.) Ching, Mandevilla fragrans (Stadelm.) Woodson, Pitcairnia paniculata (Ruiz \& Pav.) Ruiz \& Pav., Pouzolzia poeppigiana (Wedd.) Killip, Rubus urticifolius Poir., Viburnum reticulatum (Ruiz \& Pav. ex Oerst.) Killip, and Weinmannia spruceana Engl.

Humid thermotropical forests from Northern Peru (Cajamarca Region), on clayey soils of Tertiary volcanic origin and quaternary sediments with a slope up to $60 \%$. The trees can reach a canopy of $20 \mathrm{~m}$.

Muntingia calabura-Hura crepitans community

Plot 243 (Tamborapa, Cajamarca, $575 \mathrm{~m}$ above sea level, $5^{\circ} 25^{\prime} 44.42^{\prime \prime} \mathrm{S} / 78^{\circ} 57^{\prime} 39.38^{\prime \prime} \mathrm{W}$ ) (Supplementary Table S2). Diagnostic species: Albizia multiflora (Kunth) Barneby \& J.W. Grimes, Hura crepitans, Ichnanthus nemorosus (Sw.) Döll, Leucaena trichodes (Jacq.) Benth., Muntingia calabura, Paullinia alata (Ruiz \& Pav.) G. Don, Piper nudilimbum C. DC., P. peltatum L., and Ruellia brevifolia (Pohl) C. Ezcurra.

Forests overlooked by Hura crepitans, with a tree canopy of approximately $20 \mathrm{~m}$, located on very clayey soils with periodic flooding under a sub-humid infratropical bioclimate, in areas near the Marañón River.

Hypolepido parallelogrammae-Alnetum acuminatae ass. nov.

Holotypus: Appendix A Table A2; Plot 278, Supplementary Table S2. Diagnostic species: Acanthus ilicifolius L., Asplenium auriculatum Sw., Aulonemia longiaristata L.G. Clark \& Londoño, Cyathea herzogii Rosenst., Cyathea lechleri, Geonoma orbignyana, Hedyosmum sprucei Solms, Hypolepis parallelogramma (Kunze) C. Presl, Hypolepis obtusata (C. Presl) Kuhn, Inga acuminata Benth., Miconia aff asperrima Triana, Miconia aggregata, Saccoloma inaequale (Kunze) Mett., and Serpocaulon fraxinifolium.

Humid thermotropical alder forest, with tree ferns and a large number of shady ferns on black hydromorphic soils on gentle slopes (up to $40 \%$ ). It forms a forest canopy of about $30 \mathrm{~m}$ in mountain areas south of the Huancabamba depression.

Lueheo divaricatae-Ceroxylonetum peruviani ass. nov.

Holotypus: Appendix A Table A2; Plot 284, Supplementary Table S2. Diagnostic species: Austroeupatorium inulaefolium (Kunth) R.M. King \& H. Rob., Ceroxylon peruvianum Galeano, Sanín \& K. Mejia, Ladenbergia oblongifolia (Humb. ex Mutis) L. Andersson, Luehea divaricata Mart., Pueraria phaseoloides (Roxb.) Benth., Schistocarpha sinforosi Cuatrec., Styloceras laurifolium, and Viburnum incarum Graebn.

Forest of the endemic palm Ceroxylum peruvianum, which is only distributed in the eastern Andes of the Amazonas department. It is a mesotropical humid forest that sits on hydromorphic soils near watercourses and slopes (20-40\%) with permanent water. The tree canopy is about $20 \mathrm{~m}$.

Mutisio wurdackii-Alnetum acuminatae ass. nov.

Holotypus: Appendix A Table A2; Plot 286, Supplementary Table S2. Diagnostic species: Cortaderia jubata (Lemoine ex Carrière) Stapf, Mutisia wurdackii Cabrera, and Weinmannia costulata Cuatrec.

Alder forest in northern Peru, found in permanent water courses forming a gallery of trees that reach $15 \mathrm{~m}$ canopy, under a subhumid thermotropical bioclimate.

Axinaeo tomentosae-Ceroxylonetum quindiuensis ass. nov.

Holotypus: Appendix A Table A2; Plot 289, Supplementary Table S2. Diagnostic species: Axinaea tomentosa Cogn., Cedrela odorata L., Ceroxylon quindiuense (H. Karst) H. Wendl., Citronella incarum (J.F. MacBr.) R.A. Howard, Cornus peruviana, Cronquistianthus chachapoyensis R.M. King \& H. Rob., 
Erythrina aff edulis Micheli, Hedyosmum lechleri Solms, Vismia pozuzoensis Engl., Solanum barbulatum Zahlbr., and Viburnum pichinchense Benth.

Palm grove dominated by Ceroxylon quindiuense, whose canopy is up to $30 \mathrm{~m}$. It sits on peaty soil under a subhumid thermotropical bioclimate with a flat or slightly concave relief. It is an endemic association of the Eastern Andes in the departments of Amazonas and Cajamarca.

Piperi chanchamayani-Cecropietum strigosae ass. nov.

Holotypus: Appendix A Table A2; Plot 293, Supplementary Table S2. Diagnostic species: Adiantum raddianum C. Presl, Ageratina tambillensis (Hieron.) R.M. King \& H. Rob., Anthurium grande W. Bull, Canna paniculata Ruiz \& Pav., Cavendishia punctata (Ruiz \& Pav. Ex J. St. Hil.) Sleumer, Cecropia angustifolia, Cecropia strigosa Trécul, Centropogon altus E. Wimm., Chromolaena leptocephala (DC.) R.M. King \& H. Rob., Coriaria myrtifolia L., Meriania tomentosa (Cogn.) Wurdack, Miconia sanguinea (D. Don) Triana, Pilea pavonii Wedd., Psammisia coarctata (Ruiz \& Pav.) A.C. Sm., Solanum asperolanatum Ruiz \& Pav., Solanum mite Ruiz \& Pav., and Thelypteris euchlora (Sodiro) C.F. Reed.

Hyperhumid upper thermotropical forest with Cecropia from central Peru (Chanchamayo area) developing on clay-rich soils, with slopes of up to $40 \%$ and a tree canopy of up to $25 \mathrm{~m}$.

Cedrelo fissilis-Ficetum maximae ass. nov.

Holotypus: Appendix A Table A2; Plot 298, Supplementary Table S2. Diagnostic species: Alsophila mostellaria Lehnert, Begonia parviflora Poepp. \& Endl., Campyloneurum ophiocaulon (Klotzsch) Fée, Centropogon granulosus C. Presl, Columnea inaequilatera Poepp. \& Endl., Croton lechleri Müll. Arg., Ficus maxima Mill., Heliconia subulata Ruiz \& Pav., Inga adenophylla Pittier, Lastreopsis effusa (Sw.) Tindale, Nephrolepis pectinata (Willd.) Schott, Ocotea obovata (Ruiz \& Pav.) Mez, Pteris altissima Poir., Selaginella trisulcata Aspl., Serjania communis Cambess., Serpocaulon loriceum (L.) A.R. Sm., Prestoea carderi (W. Bull) Hook. f., Thelypteris jamesonii (Hook.) R.M. Tryon, Thelypteris salzmannii (Fée) C.V. Morton, Vernonanthura patens (Kunth) H. Rob., Urera baccifera, and Urera verrucosa (Liebm.) V.W. Steinm.

Hyperhumid thermotropical forest of central Peru periodically flooded with clayey soils with certain hydromorphism. It is located on gentle slopes $(0-40 \%)$. Ficus and Cedrela are prominent in the canopy, reaching about $20 \mathrm{~m}$.

Cecropio albicantis-Weinmannietum glomeratae ass. nov.

Holotypus: Appendix A Table A2; Plot 300, Supplementary Table S2. Diagnostic species: Ageratina rhytidodes (B.L. Rob.) R.M. King \& H. Rob., Bomarea pseudopurpurea Hofreiter \& E. Rodr., Cavendishia nobilis Lindl., Cecropia albicans Trécul, Centropogon hirtus (G. Don) C. Presl, Centropogon reflexus C. Presl, Dioscorea mitoensis R. Knuth, Disterigma acuminatum, Elleanthus aurantiacus (Lindl.) Rchb. f., Miconia galactantha Naudin, Piper augustum Rudge, Sticherus revolutus (Kunth) Ching, Thelypteris pachyrhachis (Kunze ex Mett.) Ching, Tibouchina lepidota (Bonpl.) Baill., Tibouchina saxosa Gleason, Vaccinium crenatum (G. Don) Sleumer, Weinmannia auriculata D. Don, Weinmannia latifolia C. Presl, and Weinmannia microphylla Kunth.

Hyperhumid mesotropical forest of central Peru rich in Weinmannia species, with a forest canopy of 10-15 m, located on very clayey soils, reddened by iron oxides, with a relief of steep slopes ( $40-60 \%)$.

\section{Clusia trochiformis-Cecropia utcubambana Community}

Plot 305 (Below Carpish, Huánuco, $1762 \mathrm{~m}$ above sea level, 9²8'02.02' S/76 00'02.93" W) (Supplementary Table S2). Diagnostic species: Barnadesia corymbosa (Ruiz \& Pav.) D. Don, Canna bangii Kraenzl., Dryopteris patula, Fuchsia macrophylla I.M. Johnst., Margaritopsis boliviana (Standl.) C.M. Taylor, Palicourea angustifolia, Piper semicordulatum Trel., Schefflera pentandra (Pav.) Harms, and Serpocaulon adnatum (Kunze ex Klotzsch) A.R. Sm.

Hyperhumid lower thermotropical forest dominated by Cecropia utcubambana that reaches a height of about $20 \mathrm{~m}$. We have only been able to carry out one plot on brown clay soils with a steep slope (50\%). 
Chelyocarpo ulei-Acacietum loretensis ass. nov.

Holotypus: Appendix A Table A2; Plot 306, Supplementary Table S2. Diagnostic species: Acacia loretensis J.F. Macbr., Acalypha stricta Poepp., Banara guianensis Aubl., Bauhinia tarapotensis Benth., Boehmeria pavonii Wedd, Chelyocarpus ulei Dammer, Clitoria pozuzoensis J.F. Macbr., Corytoplectus speciosus (Poepp.) Wiehler, Heliconia rostrata Ruiz \& Pav., Miconia amplexicaulis Naudin, Paullinia serjaniifolia Triana \& Planch., Perebea angustifolia (Poepp. \& Endl.) C.C. Berg, Piper arboreum, Polybotrya caudata Kunze, Selaginella haematodes (Kunze) Spring, Sloanea ptariana Steyerm., Tectaria antioquoiana (Baker) C. Chr., and Thelypteris patens (Sw.) Small.

Ultra-hyperhumid infratropical Amazon forests, from the lowest parts, with a hilly relief of the Peruvian Andes ( $800 \mathrm{~m}$ above sea level). They are settled on very yellowish silty soils, with slopes of up to $50 \%$, and a tree canopy of about $30 \mathrm{~m}$. The presence of the palm Chelyocarpus ulei indicates the Amazonian character of this forest, as does Heliconia rostrata and wild forms of Theobroma cacao L.

\subsubsection{Describing New Alliances, Orders and Classes}

With this work, we have been able to extend the forest communities with Andean alders. In the north of Peru, it is differentiated with the Cyatheo herzogii-Alnion acuminatae all. nov., the montane thermotropical forests on clayey soils with hydromorphism-holotypus alliance: Hypolepido parallelogrammae-Alnetum acuminatae ass. nov.; diagnostic species: The same as in the association. On the other hand, the other associations (Lueheo divaricatae-Ceroxylonetum peruviani ass. nov., Mutisio wurdackii-Alnetum acuminatae ass. nov., and Axinaeo tomentosae-Ceroxylonetum quindiuensis ass. nov.), which are riverside and peatland forests from Northern Peru, are brought together in the Escallonio pendulae-Alnion acuminatae all. nov.-holotypus alliance: Axinaeo tomentosae-Ceroxylonetum quindiuensis ass. nov.; diagnostic species: Bia alienata Didr., Escallonia pendula (Ruiz \& Pav.) Pers., Ladenbergia oblongifolia, Pentacalia reflexa (Kunth) Cuatrec., Thelypteris pennata (Poir.) C.V. Morton, and Styloceras laurifolium. All these alder forest alliances belong to the order Alnetalia acuminatae ord. nov. and the class Alnetea acuminatae Galán de Mera 2005 (Appendix A, Table A1, blue square).

The ultra-hyperhumid montane forests of southern Peru are joined together in the Serpocaulo dasypleuronis-Alchorneion latifoliae all. nov. (Appendix A, Table A1, orange square)-holotypus alliance: Iriartello setigerae-Cinchonetum micranthae ass. nov.; diagnostic species: Alchornea latifolia Sw., Cyathea delgadii Sternb., Graffenrieda cucullata (Triana) L.O. Williams, Lasiacis ligulata Hitchc. \& Chase, Olyra latifolia L., Psychotria poeppigiana Müll. Arg., Serpocaulon dasypleuron (Kunze) A.R. Sm., and Trema micrantha (L.) Blume, while those in the north are included in the Pteridi creticae-Cyatheion caracasanae all. nov. (Appendix A, Table A1, pink square)-holotypus alliance: Viburno reticulati-Weinmannietum spruceanae ass. nov.; diagnostic species: Begonia peruviana A. DC., Cecropia utcubambana Cuatrec., Cyrtocymura scorpioides (Lam.) H. Rob., Fuchsia mathewsii J.F. Macbr., Miconia adinantha, Pennisetum peruvianum Trin., Piper lineatum Ruiz \& Pav., Pteris cretica L., and Seemannia sylvatica (Kunth) Baill. The forests of central Peru belong to the Sanchezio oblongae-Hedyosmion racemosi all. nov. (Appendix A, Table A1, green square)-holotypus alliance: Cecropio albicantis-Weinmannietum glomeratae ass. nov.; diagnostic species: Anthurium breviscapum Kunth, Baccharis decussata subsp. jelskii (Hieron.) Joch. Müll., Blepharodon salicinus Decne., Cedrela fissilis, Clusia trochiformis Vesqne, Dennstaedtia auriculata H. Navarrete \& B. Øllg., Diplazium tungurahuae (Sodiro) C. Chr., Dryopteris wallichiana (Spreng.) Hyl., Fuchsia ovalis Ruiz \& Pav., Hedyosmum racemosum, Geonoma stricta (Poit.) Kunth, Gurania lobata (L.) Pruski, Iresine diffusa Humb. \& Bonpl. ex Willd., Liabum nudicaule H. Rob., Miconia affinis DC., Miconia cyanocarpa Naudin, Monnina marginata C. Presl, Monstera obliqua Miq., Niphidium albopunctatissimum Lellinger, Oreopanax polycephalus Harms, Palicourea guianensis Aubl., Passiflora rubra L., Pilea haenkei Killip, Piper chanchamayanum Trel., Piper malifolium Trel., Pteris podophylla Sw., Pteris quadriaurita Retz., Sanchezia oblonga Ruiz \& Pav., Weinmannia glomerata C. Presl, and Zeugites americanus Willd.

The Peruvian alliances can be gathered in the new order Saurauio peruvianae-Condaminetalia corymbosae ord. nov.-holotypus order: Sanchezio oblongae-Hedyosmion racemosi all. nov.; diagnostic species: Ageratina sternbergiana (DC.) R.M. King \& H. Rob., Alchornea glandulosa Poepp., 
Baccharis inamoena Gardner, Begonia cyathophora Poepp. \& Endl., Blechnum cordatum (Desv.) Hieron., Blechnum occidentale, Cavendishia bracteata (Ruiz \& Pav. ex J. St. Hil) Hoerold, Cinchona pubescens Vahl, Condaminea corymbosa (Ruiz \& Pav.) DC., Conostegia inusitata Wurdack, Ctenitis sloanei (Poepp. ex Spreng.) C.V. Morton, Cyathea caracasana (Klotzsch) Domin, Dioscorea altissima Lam., Disterigma alaternoides (Kunth) Nied., Heliocarpus americanus, Morella pubescens, Munnozia hastifolia (Poepp.) H. Rob. \& Brettell, Myriocarpa stipitata Benth., Myrsine coriacea, Nephrolepis cordifolia (L.) C. Presl, Niphidium crassifolium (L.) Lellinger, Ochroma pyramidale (Cav. ex Lam.) Urb., Palicourea amethystina (Ruiz \& Pav.) DC., Polystichum montevidense (Spreng.) Rosenst., Pteridium arachnoideum (Kaulf.) Maxon, Saurauia peruviana, Schefflera acuminata (Pav.) Harms, Serpocaulon caceresii (Sodiro) A.R. Sm., Siparuna aspera (Ruiz \& Pav.) A. DC., Smilax domingensis Willd., Tradescantia cymbispatha C.B. Clarke, and Vismia tomentosa Ruiz \& Pav., and in the new phytosociological class Morello pubescentis-Myrsinetea coriaceae cl. nov., whose diagnostic species are those of the order. Both order and class may exceed the territory of Peru, judging by the species common with Venezuela, Colombia, Ecuador, Bolivia, and Argentina.

\section{Discussion}

\subsection{Relationships among South American Montane Rainforests}

According to Table 1, the mountain forests of Peru bear a greater resemblance from a floristic point of view to those of Ecuador and to the sum of the entire Colombian Andes than to those of Bolivia. However, as shown in the dendrogram in Figure 1, the forests of Peru form a well-defined unit, probably because they are confined between the Huancabamba depression in the north and the Abancay deflection in the south [55]. The depression of Huancabamba separates the north from the center of the Andes, while in the deflection of Abancay, the eastern cordillera begins a granitic arch from the basin of the Urubamba River towards the South [56], with the characteristic forests of the alliance Serpocaulo dasypleuronis-Alchorneion latifoliae all. nov. However, many characteristic species of the new class Morello pubescentis-Myrsinetea coriaceae cl. nov. are also found in Ecuador and Colombia (Appendix A, Table A1), so this class could go beyond the Peruvian Andes. On the other hand, we do not know of a phytosociological class from the humid-ultrahyperhumid Andes of Ecuador [46,57]. In the Eastern Cordillera of Colombia, the class Palicoureo leuconerae-Cybianthetea iteoides Rangel, Cleef \& Arellano 2008 has been described, but without following the precepts of the Code [44]. In a previous paper [18], we had established the class Nectandro laurel-Licarietea cannellae Izco 2013 [57] in Peru, and although some of its characteristics, such as Licaria canella (Meisn.) Kosterm., Isertia laevis (Triana) Boom, or Guzmania killipiana L.B. Sm., exist in Peru, its presence is not evident in our plots.

The forests of Bolivia are different from those of Peru, due to the elements common with the forests to the south of the Amazonian basin, in Brazil, Paraguay, and Argentina, such as Inga saltensis Burkart, Juglans australis, Myrcianthes mato, Ocotea porphyria, Podocarpus parlatorei, and Schinopsis brasiliensis Engl. [47], and the forests of Argentina, even those of the Parana basin, such as Allophylus edulis (A. St.-Hil., A. Juss. \& Cambess.) Radlk., Baccharis coridifolia DC., Blepharocalyx salicifolius (Kunth) O. Berg, Myrsine laetevirens (Mez) Arechav., or Sebastiania commersoniana (Baill.) L.B. Sm. \& Downs [35,50].

\subsection{Phytosociological Units Previously Described}

According to Appendix A, Table A1, the rainforest with Polylepis-Mutisia cochabambensis-Polylepis incarum community - of Southern Peru belong to the Polylepidion incano-besseri Navarro in Navarro \& Maldonado 2002 alliance, the Andean Polylepidetalia racemosae Galán de Mera \& Cáceres in Galán de Mera, Rosa \& Cáceres 2002 order, and Polylepidetea tarapacano-besseri Rivas-Martínez \& Navarro in Navarro \& Maldonado 2002 class [58,59]. In Ecuador, we also find Polylepis forests that belong to the same class [45], but the phytosociological units described with Polylepis incana Kunth, Polylepis pauta Hieron., and Polylepis sericea Wedd., do not follow the Code, although they clearly constitute different associations with the Peruvian ones. The eastern associations in Bolivia also constitute different communities from those of Peru, as they are dominated by Polylepis besseri Hieron. [60], absent from 
Peru, and Polylepis tomentella Wedd., which forms forests both in Bolivia [61] and in eastern areas of Peru [62], where other associations could be described.

Classes Pruno rigidae-Oreopanacetea floribundi Galán de Mera 2005 (Appendix A, Table A1, red square) and Clematido peruvianae-Baccharitetea latifoliae Galán de Mera, Sánchez Vega, Montoya, Linares, Campos \& Vicente 2015 (Appendix A, Table A1, grey square) are well represented in at least subhumid areas of the Peruvian Andes. Pruno-Oreopanacetea includes the new associations Smallantho parvicipitis-Oreopanacetum eriocephali ass. nov. and Crotono churumayensis-Hesperomeletum ferrugineae ass. nov., and the previously described Axinaeo nitidae-Podocarpetum oleifolii Galán de Mera, Sánchez Vega, Montoya, Linares, Campos \& Vicente 2015-north western Peruvian humid-hyperhumid mesotropical laurel-like forest, Verbesino auriculigerae-Siparunetum muricatae Galán de Mera, Sánchez Vega, Montoya, Linares, Campos \& Vicente 2015-humid-hyperhumid mesotropical laurel-like forest of anthropic origin by disturbance of the previous one, Berberido beauverdianae-Myrcianthetum myrsinoidis Galán de Mera, Sánchez Vega, Montoya, Linares, Campos \& Vicente 2015—north western Peruvian subhumid-humid mesotropical forest: they are found at higher altitudes and lower humidity, in contact with Podocarpus oleifolius forests, and Aristeguietio discoloris-Kageneckietum lanceolatae Galán de Mera, Sánchez Vega, Montoya, Linares, Campos \& Vicente 2015-dry-subhumid upper mesotropical forests of the western Andes of Northern Peru. Although Smallantho parvicipitis-Oreopanacetum eriocephali ass. nov. and Crotono churumayensis-Hesperomeletum ferrugineae ass. nov. are eastern associations, we consider them part of the Monnino pilosae-Myrcianthion myrsinoidis Galán de Mera, Sánchez Vega, Montoya, Linares, Campos \& Vicente 2015 alliance and the Cestro auriculati-Prunetalia rigidae Galán de Mera \& Rosa in Galán de Mera, Rosa \& Cáceres 2002 order, despite being less rich in characteristics [18], since both Monnina pilosa Kunth and Myrcianthes myrsinoides (Kunth) Grifo are widely distributed on the eastern Andean slopes.

The Clematido peruvianae-Baccharitetea latifoliae class includes shrub communities (Appendix A, Table A1, grey square), which constitute the succession of the Pruno rigidae-Oreopanacetea floribundi class in wet areas. Here, we have studied the previously described associations Baccharito latifoliae-Monactinetum flaverioidis Galán de Mera, Sánchez Vega, Montoya, Linares, Campos \& Vicente 2015 and Monactino flaverioidis-Colignonietum parviflorae Galán de Mera, Sánchez Vega, Montoya, Linares, Campos \& Vicente 2015. Both are from subhumid-humid areas, but the first is a supratropical association while the second is mesotropical, and they are part of the alliance Otholobio munyensis-Rubion robusti Galán de Mera, Sánchez Vega, Montoya, Linares, Campos \& Vicente 2015 [18], which replaces Mutisio acuminatae-Ophryosporion peruvianae Galán de Mera \& Cáceres in Galán de Mera, Rosa \& Cáceres 2002 in northern Peru [58], and Saturejion bolivianae Seibert \& Menhofer 1991 in eastern Bolivia [63]. All these alliances are included in the order Mutisio acuminatae-Baccharitetalia latifoliae Galán de Mera \& Cáceres in Galán de Mera, Rosa \& Cáceres 2002.

In our study, there are three Amazonian associations (Appendix A, Table A1, columns 14, 23, and 24), the new association Chelyocarpo ulei-Acacietum loretensis and the previously described Oenocarpo maporae-Mauritietum flexuosae Galán de Mera 1996 [64] and Pachiro brevipedis-Euterpetum catingae Galán de Mera 2001 [65]. We have included the sub-Andean Chelyocarpo ulei-Acacietum loretensis within Morello pubescentis-Myrsinetea coriaceae cl. nov., although it has certain similarities with the communities of the Colombian sub-Andean class Smilaco floribundae-Ingetea edulis Rangel, Cleef \& Salamanca in Rangel, Cleef, Salamanca \& Ariza 2005 [43], especially due to the presence of Smilax domingensis Willd. and Inga edulis Mart. However, species such as Cnemidaria quitensis (Domin) R.M. Tryon, Otoba lehmannii (A.C. Sm.) A.H. Gentry, Ossaea bracteata Triana, Schefflera bejucosa Cuatrec., or Wettinia radiata (O.F. Cook \& Doyle) R. Bernal were not found in the Peruvian forests. The palm groves Oenocarpo-Mauritietum and Pachiro-Euterpetum are edapho-hygrophilous associations of the ultra-hyperhumid infratropical belt of the lower Amazonia. Their floristic composition is very different with respect to the class Morello pubescentis-Myrsinetea coriaceae, since the palms Oenocarpus bataua Mart., Oenocarpus mapora H. Karst., Mauritia flexuosa, and Euterpe catinga become dominant, as well as in other forests of the Colombian 
Amazonia [66], and in the Orinoco plains of Venezuela [67] and Colombia [68]; therefore, they surely constitute a particular class.

\subsection{Syntaxonomical Checklist for the Montane Rainforests of Peru}

This scheme was ordered according to the plant communities and groups of Appendix A, Table A1. Polylepidetea tarapacano-besseri Rivas-Martínez \& Navarro in Navarro \& Maldonado 2002

Polylepidetalia racemosae Galán de Mera \& Cáceres in Galán de Mera, Rosa \& Cáceres 2002

Polylepidion incano-besseri Navarro in Navarro \& Maldonado 2002

Mutisia cochabambensis-Polylepis incarum community

Pruno rigidae-Oreopanacetea florifundae Galán de Mera 2005

Cestro auriculati-Prunetalia rigidae Galán de Mera \& Rosa in Galán de Mera, Rosa \& Cáceres 2002

Monnino pilosae-Myrcianthion myrsinioidis Galán de Mera, Sánchez Vega, Montoya, Linares, Campos \& Vicente 2015

Axinaeo nitidae-Podocarpetum oleifolii Galán de Mera, Sánchez Vega, Montoya, Linares, Campos \& Vicente 2015

Verbesino auriculigerae-Siparunetum muricatae Galán de Mera, Sánchez Vega, Montoya, Linares, Campos \& Vicente 2015

Berberido beauverdianae-Myrcianthetum myrsinoidis Galán de Mera, Sánchez Vega, Montoya, Linares, Campos \& Vicente 2015

Aristeguietio discoloris-Kageneckietum lanceolatae Galán de Mera, Sánchez Vega, Montoya, Linares, Campos \& Vicente 2015

Smallantho parvicipitis-Oreopanacetum eriocephali ass. nov.

Crotono churumayensis-Hesperomeletum ferrugineae ass. nov.

Clematido peruvianae-Baccharitetea latifoliae Galán de Mera, Sánchez Vega, Montoya, Linares, Campos \& Vicente 2015

Mutisio acuminatae-Baccharitetalia latifoliae Galán de Mera \& Cáceres in Galán de Mera, Rosa \& Cáceres 2002

Otholobio munyensis-Rubion robusti Galán de Mera, Sánchez Vega, Montoya, Linares, Campos \& Vicente 2015

Baccharito latifoliae-Monactinetum flaverioidis Galán de Mera, Sánchez Vega, Montoya, Linares, Campos \& Vicente 2015

Monactino flaverioidis-Colignonietum parviflorae Galán de Mera, Sánchez Vega, Montoya, Linares, Campos \& Vicente 2015

Alnetea acuminatae Galán de Mera 2005

Alnetalia acuminatae Galán de Mera \& Rosa in Galán de Mera, Rosa \& Cáceres 2002

Cyatheo herzogii-Alnion acuminatae all. nov.

Hypolepido parallelogrammae-Alnetum acuminatae ass. nov.

Escallonio pendulae-Alnion acuminatae all. nov.

Lueheo divaricatae-Ceroxylonetum peruviani ass. nov.

Mutisio wurdackii-Alnetum acuminatae ass. nov.

Axinaeo tomentosae-Ceroxylonetum quindiuensis ass. nov.

Morello pubescentis-Myrsinetea coriaceae cl. nov.

Saurauio peruvianae-Condaminetalia corymbosae ord. nov.

Serpocaulo dasypleuronis-Alchorneion latifoliae all. nov.

Iriartello setigerae-Cinchonetum micranthae ass. nov.

Acalypho macrostachyae-Cecropietum polystachyae ass. nov.

Pteridi creticae-Cyatheion caracasanae all. nov.

Viburno reticulati-Weinmannietum spruceanae ass. nov.

Muntingia calabura-Hura crepitans community

Sanchezio oblongae-Hedyosmion racemose all. nov. 
Piperi chanchamayani-Cecropietum strigosae ass. nov.

Cedrelo fissilis-Ficetum maximae ass. nov.

Cecropio albicantis-Weinmannietum glomeratae ass. nov.

Clusia trochiformis-Cecropia utcubambana community

Chelyocarpo ulei-Acacietum loretensis ass. nov.

Insertae sedis

Oenocarpo maporae-Mauritietum flexuosae Galán de Mera 1996

Pachiro brevipedis-Euterpetum catingae Galán de Mera 2001

\section{Materials and Methods}

\subsection{Study Area}

The mountain rainforests of the western and eastern slopes of the Peruvian Andes were studied $\left(4^{\circ} 29^{\prime} 34.1^{\prime \prime} \mathrm{S}\right.$ to $\left.14^{\circ} 37^{\prime} 52.68^{\prime \prime} \mathrm{S}\right)$ : on the north, those located in the vicinity of the Huancabamba depression $\left(5^{\circ} 48^{\prime} 0 \mathrm{~S}\right)$, and on the south, those located in the surroundings of the Abancay deflection $\left(13^{\circ} 16^{\prime} 37.22^{\prime \prime}\right.$ S) [55], which are joined to those of central Peru (Figure 2).

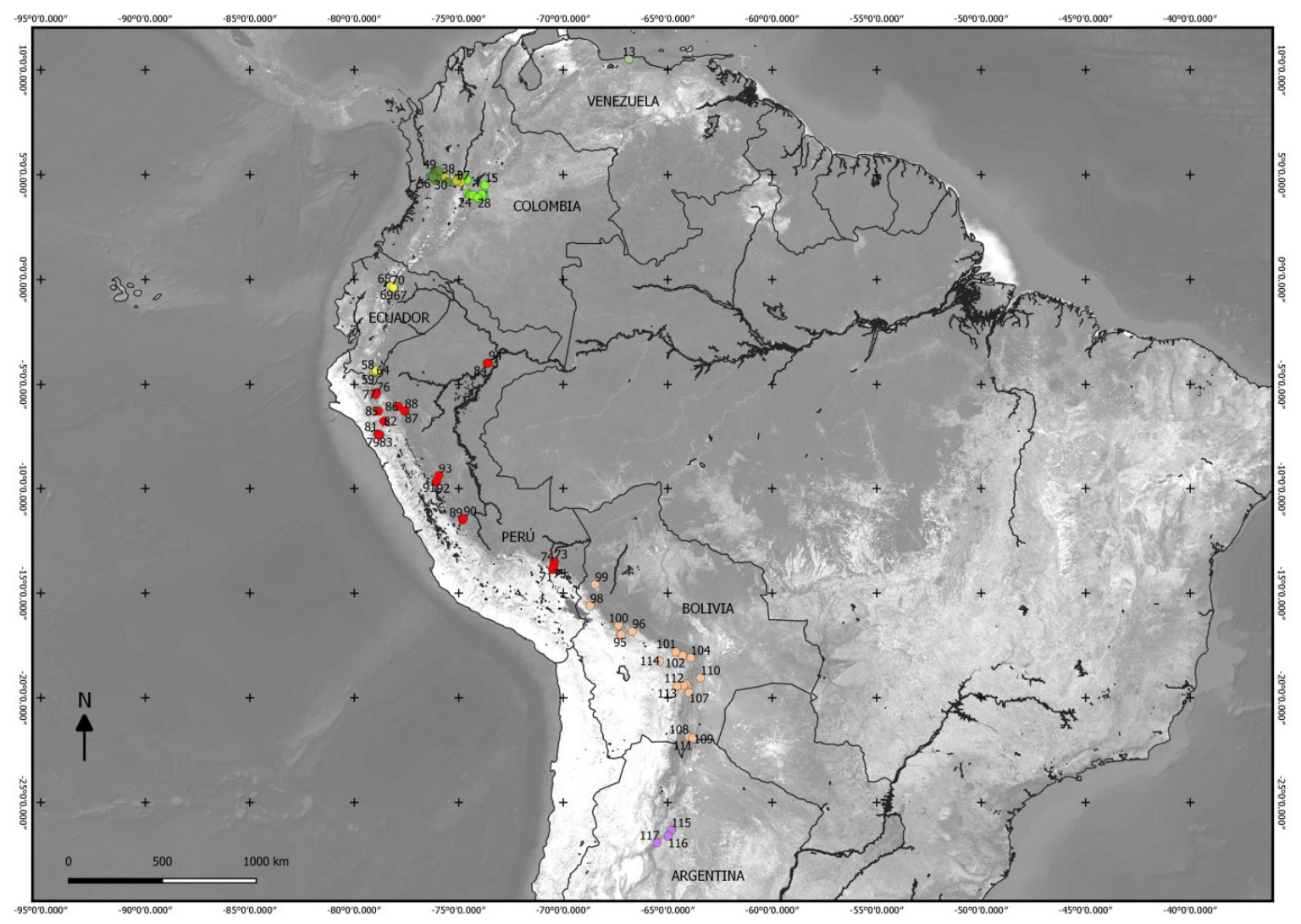

Figure 2. Map of tropical South America with the areas studied in Peru and surrounding countries. Numbers of dots correspond to those of Supplementary Tables S1 and S3. Map generated by Quantum Geographic Information System (QGIS) 3.0.1 software [69].

The forests were studied at altitudes between 575 and $3786 \mathrm{~m}$ above sea level, with some of them located in lowland Amazonian forest at an elevation between 120 and $150 \mathrm{~m}$. In general, they are situated in the eastern Andean mountain range, on Paleozoic granite and metamorphic rocks, although Jurassic limestone outcrops are frequent. However, in the north, Tertiary volcanism abounds in the western territories, as well as Quaternary sediments and marine volcanic sedimentary facies in the area of the Marañón River [70]. 
From a biogeographical point of view, Peruvian montane rainforests belong to Yungenian Province (Tropical Subandean Region, Neotropical-Austroamerican Kingdom) with a tropical pluvial bioclimate [27]. To examine altitudinal relationships between climate and forest plant communities, the bioclimatic system of Rivas-Martínez [71] was applied, using data for at least 30 years [72], from several meteorological stations as near as possible to the studied forests using the location coordinates of the forests and the stations found on Google Earth Pro@ (Supplementary Table S1). We used this method because it precisely reflects the correspondence between bioclimatic belts and vegetation associations.

This bioclimatic model is based on thresholds of the Thermicity index (It) versus the intervals of annual precipitations ( $\mathrm{P}$ in $\mathrm{mm}$ ) (we did not use the humidity index (Io) because results do not reflect a vegetation type on some occasions) coincident with altitudinal and latitudinal areas of flora and vegetation, called bioclimatic belts. The Thermicity index is based on mean annual temperature $\left(\mathrm{T}\right.$ in $\left.{ }^{\circ} \mathrm{C}\right)$, and average maximum $(\mathrm{M})$ and minimum $(\mathrm{m})$ temperatures of the coldest month $(\mathrm{It}=(\mathrm{T}+\mathrm{M}$ $+\mathrm{m})$ 10). Bioclimatic belts coincide with natural plant associations, and for Peru, six bioclimatic belts were defined and mapped [73]: Infratropical (It > 690), thermotropical (It 490 to 690), mesotropical (It 320 to 490), supratropical (It 160 to 320), orotropical (It 50 to 160), and cryorotropical (It $<50$ ). P (in $\mathrm{mm}$ ) intervals are the following: Ultra-hyperarid ( $\mathrm{P}<5$ ), hyperarid (5 to 30$)$, arid (31 to 100$)$, semiarid (101 to 300), dry (301 to 500), subhumid (501 to 900), humid (901 to 1500), hyperhumid (1501 to 2500), and ultra-hyperhumid (>2500).

\subsection{Plots and Flora of Peru}

As it is very difficult to calculate the minimum phytosociological area in a mountain rainforest to carry out vegetation plots, we have established plots of $100 \mathrm{~m}^{2}$, as proposed by Dengler [74], up to $0.1 \mathrm{ha}$, as in Gentry's methods, according to the forest complexity from a subhumid area to an ultra-hyperhumid area. As Gentry pointed out, the 0.1 ha transect method is ideally suited to collect data from multiple sites, in order to generate comparative data on the taxonomic composition in rainforests [75].

To identify the flora of the plots, we especially used some specific systematic works [76-85], floristic catalogues [86-88], and the herbaria COL (National University of Colombia), CPUN (National University of Cajamarca), CUZ (National University of San Antonio Abad of Cuzco), F (Field Museum of Natural History), MO (Missouri Botanical Garden), NY (The New York Botanical Garden), P (Natural History Museum of Paris), US (Smithsonian Institution), and USM (Natural History Museum of the Mayor University of San Marcos) (acronyms according to Thiers [89]).

Plant names were updated using the database The Plant List [90].

\subsection{Relationships among South American Rainforests}

Taking a total of 364 plots and 3389 species, we built a matrix (Supplementary Table S2), in which 106 plots were carried out by the authors in Peru, and 258 came from the bibliography: 14 from Venezuela [38], 96 from Colombia [41-44], 103 from Ecuador [45,46], 24 from Bolivia [47], and 21 from Argentina [48] (Figure 2). To obtain a synthetic matrix (Supplementary Table S3) grouping species, we performed a cluster analysis with the unweighted pair-group average (UPGMA) using the Sørensen index [91] in order to observe the similarity between the columns and their linkage with precipitation intervals and bioclimatic belts. To find a numerical similarity between the mountain rainforest flora, we synthesized all plots into a single column per country with JUICE software [92], and then computed the Sørensen index. UPGMA and Sørensen index were performed using PAST 4.03 [93] software.

\subsection{Vegetation Classification}

We used the phytosociology method of Braun-Blanquet [30] for vegetation classification, the aim of which is to define vegetation units by grouping plots with similar species compositions together and arrange these units into a hierarchical system for comparing the qualitative and quantitative floristic compositions of different geographic spaces. 
To group characteristic species into phytosociological units, and to identify fidelity among plant species on plots from South America, we used JUICE software [92], with the phi coefficient as a fidelity measure [94]. This coefficient is a standard method in phytosociological studies because the phi coefficient is independent of the number of plots in the dataset. JUICE standardizes all plot groups to an equal size, and we introduced the conditions of $>30 \%$ of frequency percentage for each species, including a phi measure of $>0.2$. Species whose concentration in groups was not significant at $p<0.01$ were disregarded [95].

The phytosociological names of the vegetation units are given according to the International Code of Phytosociological Nomenclature [96].

Supplementary Materials: The following are available online at http://www.mdpi.com/2223-7747/9/12/1654/s1, Table S1: localities, bioclimatic belts, plant communities, and diagnostic plants from the rainforest studied in South America, Table S2: table with 364 plots studied in South America, Table S3: synthetic table of the plots studied in South America applying JUICE software.

Author Contributions: Conceptualization, A.G.-d.-M. and J.A.V.-O.; methodology, A.G.-d.-M., E.L.-P. and J.A.V.-O.; software, A.G.-d.-M. and E.L.-P.; validation, A.G.-d.-M., E.L.-P. and J.A.V.-O.; formal analysis, A.G.-d.-M., E.L.-P. and J.A.V.-O.; investigation, A.G.-d.-M., E.L.-P. and J.A.V.-O.; resources, I.T.-M.; data curation, J.C.-d.-I.-C. and J.M.-Q.; writing - original draft preparation, A.G.-d.-M.; writing-review and editing, A.G.-d.-M., J.C.-d.-1.-C., E.L.-P., J.M.-Q., I.T.-M. and J.A.V.-O.; visualization, A.G.-d.-M., E.L.-P. and J.A.V.-O.; supervision, A.G.-d.-M.; project administration, I.T.-M.; funding acquisition, A.G.-d.-M., E.L.-P. and I.T.-M. All authors have read and agreed to the published version of the manuscript.

Funding: This research was funded by Antonio Guillermo Urrelo Private University, grant numbers 2013 to 2019, and by the Phytogeographical Studies of Peru Foundation.

Acknowledgments: This work is dedicated to the memory of Professor Salvador Rivas-Martínez, a pioneer of Phytosociology in Peru. We are very grateful to the anonymous reviewers and to the Editor for their help in improving our paper. Thanks to the National Forest and Wildlife Service (SERFOR) for authorization 086-2017-SERFOR/DGGSPFFS, and to the Head of the Tabaconas-Namballe National Sanctuary for authorization 004-2019-SERNANP-JEF/CGM. Also, to Andrea Galán and Brian Crilly for their editorial assistance.

Conflicts of Interest: The authors declare no conflict of interest. 


\section{Appendix A}

Table A1. Synthetic table of 106 plots carried out in montane rainforests of Peru.

\begin{tabular}{|c|c|c|c|c|c|c|c|c|c|c|c|c|c|c|c|c|c|c|c|c|c|c|c|c|}
\hline Column Number & 1 & 2 & 3 & 4 & 5 & 6 & 7 & 8 & 9 & 10 & 11 & 12 & 13 & 14 & 15 & 16 & 17 & 18 & 19 & 20 & 21 & 22 & 23 & 24 \\
\hline Columns of Table S3 & 71 & 72 & 73 & 74 & 75 & 76 & 77 & 78 & 79 & 80 & 81 & 82 & 83 & 84 & 85 & 86 & 87 & 88 & 89 & 90 & 91 & 92 & 93 & 94 \\
\hline Number of plots & 1 & 5 & 7 & 7 & 3 & 6 & 1 & 5 & 3 & 5 & 4 & 7 & 2 & 2 & 8 & 5 & 2 & 4 & 3 & 6 & 5 & 1 & 4 & 10 \\
\hline Reference of plot intervals of & 214 & $215-219$ & $220-226$ & $227-233$ & $234-236$ & $237-242$ & 243 & $244-248$ & 249-251 & $252-256$ & $257-260$ & $261-267$ & $268-269$ & $270-271$ & $272-279$ & $280-284$ & $285-286$ & $287-290$ & 291-293 & 294-299 & $300-304$ & 305 & 306-309 & $310-319$ \\
\hline Average altitude $(\mathrm{m})$ & 3786 & 2273 & 752 & 1440 & 2754 & 1713 & 575 & 2519 & 2719 & 2540 & 3277 & 3260 & 2559 & 150 & 2474 & 1818 & 2337 & 2400 & 2313 & 1355 & 2654 & 1762 & 865 & 124 \\
\hline \multicolumn{25}{|c|}{ Mutisia cochabambensis-Polylepis incarum community } \\
\hline Polylepis incarum (T) & 100 & - & - & - & - & - & - & - & - & - & - & - & - & - & - & - & - & - & - & - & - & - & - & - \\
\hline Mutisia cochabambensis (C) & $\frac{100}{10}$ & - & - & - & - & - & - & - & - & - & - & - & - & - & - & - & - & - & - & - & - & - & - & - \\
\hline $\begin{array}{l}\text { Citharaxylum dentatum ( } \mathbf{S}) \\
\text { Elaphoglossum engelii }(\mathbf{H})\end{array}$ & $\frac{100}{100}$ & 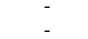 & 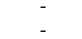 & 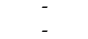 & $=$ & :- & $=$ & : & 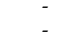 & $=$ & :- & $=$ & 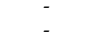 & :- & : & :- & 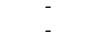 & $=$ & $=$ & : & :- & :- & :- & :- \\
\hline Gaultheria vaccinioides (SS) & $\frac{100}{100}$ & - & - & - & - & - & - & - & - & - & - & - & - & - & - & - & - & - & - & - & - & - & - & - \\
\hline \multicolumn{25}{|c|}{ Smallantho parvicipitis-Oreopanacetum eriocephali ass. nov. } \\
\hline Smallanthus parviceps (T) & - & 100 & - & - & - & - & - & - & - & - & - & - & - & - & - & - & - & - & - & - & - & - & - & - \\
\hline Fuchsia boliviana (S) & - & $\frac{100}{100}$ & - & - & - & - & - & - & - & - & - & - & - & - & - & - & - & - & - & - & - & - & - & - \\
\hline $\begin{array}{l}\text { Begonina bracteosa }(\mathbf{H}) \\
\text { Melica scabra }\end{array}$ & :- & $\frac{100}{80}$ & 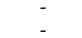 & ${ }^{14}$ & :- & :- & 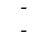 & : & - & :- & :- & :- & :- & :- & :- & :- & $\therefore$ & :- & :- & : & :- & :- & - & - \\
\hline Miconia aff adinantha (S) & - & $\frac{00}{100}$ & - & 29 & - & - & - & - & - & - & - & - & - & - & 25 & - & - & - & - & - & - & - & - & - \\
\hline Phenax angustifolius (T) & - & $\frac{60}{60}$ & - & - & - & - & - & - & - & - & - & - & - & - & 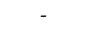 & - & - & - & - & & - & - & - & \\
\hline Solanum aphyodendron (T) & - & $\frac{60}{6}$ & - & - & - & - & - & - & - & - & - & - & - & - & - & - & - & - & - & 17 & - & - & - & - \\
\hline $\begin{array}{l}\text { Rubus boliviensis (S) } \\
\text { Pemicesum litiflum }\end{array}$ & - & $\frac{60}{40}$ & - & - & - & - & - & - & - & - & - & - & - & - & - & - & - & - & - & - & - & - & - & - \\
\hline Pennisetum latifolium $\mathbf{( H )}$ & - & $\frac{40}{40}$ & - & - & & - & - & - & - & - & - & - & - & - & - & - & & - & - & - & - & - & - & - \\
\hline Croton regelianus (S) & - & $\frac{40}{40}$ & - & - & - & - & - & - & - & - & - & - & - & - & - & - & - & - & - & - & - & - & - & - \\
\hline $\begin{array}{l}\text { Canna iridiflora }(\mathbf{H}) \\
\text { Sambucus peruviana }(\mathbf{T})\end{array}$ & : & $\frac{\overline{40}}{40}$ & : & 14 & : & : & : & : & : & : & : & : & : & : & : & : & : & : & : & - & : & : & : & : \\
\hline \multicolumn{25}{|c|}{ Iriartello setigerae-Cinchonetum micranthae ass. nov. } \\
\hline Cinchona micrantha $(\mathbf{T})$ & - & - & 100 & - & - & - & - & - & - & - & - & - & - & - & - & - & - & - & - & - & - & - & - & - \\
\hline Iriartella setigera $(\mathbf{S})$ & - & - & $\frac{\overline{100}}{71}$ & - & - & - & - & - & - & - & - & - & - & - & - & - & - & - & - & - & - & - & - & \\
\hline Cyathea subincisa $(\mathbf{T})$ & - & - & $\frac{\overline{71}}{71}$ & - & - & - & - & - & - & - & - & - & - & - & - & - & - & - & - & - & - & - & - & - \\
\hline Philodendron rudgeanum (Ер) & - & - & $\frac{71}{86}$ & - & - & - & - & - & - & - & - & - & - & - & - & - & - & - & - & - & - & - & $=$ & - \\
\hline Heliconia hirsuta $(\mathbf{H})$ & - & - & $\frac{86}{57}$ & - & - & - & - & - & - & - & - & - & - & - & - & - & - & - & - & - & - & - & 25 & - \\
\hline $\begin{array}{l}\text { Ruagea insignis (T) } \\
\text { Dofffanghchin humilis }(\mathbf{H}\end{array}$ & - & - & $\frac{57}{57}$ & - & - & - & $\therefore$ & - & - & :- & - & - & :- & - & - & - & - & - & - & - & - & - & - & - \\
\hline $\begin{array}{l}\text { Dieffenbachia humilis (H) } \\
\text { Miconialorteriainn (T) }\end{array}$ & :- & :- & $\frac{57}{57}$ & :- & :- & :- & $\because$ & :- & $=$ & - & :- & :- & : & - & - & - & :- & - & :- & :- & - & - & - & - \\
\hline Aphelandra aurantiaca (S) & - & - & $\frac{\pi}{43}$ & - & - & - & - & - & - & - & - & - & - & - & - & - & - & - & - & - & - & - & - & - \\
\hline 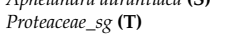 & - & - & $\frac{\frac{515}{43}}{43}$ & - & & - & - & - & - & - & - & - & - & - & - & - & & - & - & - & - & - & - & - \\
\hline Smilax purhampuy (C) & & & $\frac{\overline{43}}{12}$ & 14 & - & - & - & & - & - & - & - & - & - & - & - & - & - & - & 17 & - & - & 25 & - \\
\hline Strychnos sp..sg (S) & - & 20 & $\frac{\frac{50}{43}}{\underline{3}}$ & - & - & - & - & - & - & - & & - & - & - & - & & - & - & - & - & - & & - & - \\
\hline \multicolumn{25}{|c|}{ Acalypho macrostachyae-Cecropietum polystachyae ass. nov. } \\
\hline Cecropia polystachya (T) & - & 20 & - & 100 & - & - & - & - & - & - & - & - & - & - & - & - & - & - & - & - & - & - & - & - \\
\hline 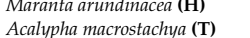 & 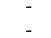 & : & 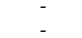 & $\frac{43}{43}$ & :- & - & - & :- & 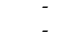 & 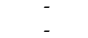 & :- & :- & :- & :- & 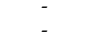 & :- & :- & :- & :- & 17 & 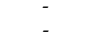 & 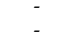 & 25 & :- \\
\hline \multicolumn{25}{|c|}{ Crotono churumayensis-Hesperomeletum ferrugineae ass. nov. } \\
\hline Croton churumayensis (T) & - & - & - & - & 100 & - & - & - & - & - & - & - & - & - & - & - & - & - & - & - & - & - & - & - \\
\hline Cuphea cordata (S) & & & - & - & $\underline{100}$ & - & - & & - & & - & - & - & - & - & - & - & - & - & - & - & - & - & - \\
\hline $\begin{array}{l}\text { Tagetes elliptica (S) } \\
\text { Senun birstris (S) }\end{array}$ & - & - & - & - & $\frac{67}{67}$ & - & - & - & - & - & - & 29 & : & - & - & - & - & - & - & - & - & - & - & - \\
\hline $\begin{array}{l}\text { Senna birostriri }(\mathbf{S}) \\
\text { Adiantum divitatum }(\mathbf{H})\end{array}$ & - & - & - & - & $\frac{67}{67}$ & - & - & 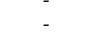 & - & - & - & - & $\therefore$ & :- & - & - & $\because$ & :- & - & :- & - & - & - & - \\
\hline 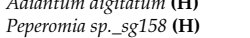 & - & - & - & - & $\frac{\pi}{33}$ & - & - & - & - & - & - & - & - & - & - & - & & - & - & - & - & - & - & - \\
\hline Miconia alpina (S) & - & - & - & - & $\frac{\overline{33}}{22}$ & - & - & - & - & - & - & - & - & - & - & & - & - & - & - & - & & - & - \\
\hline Gaultheria reticulata (S) & & & & - & $\underline{33}$ & & & & & & & & & & & & & & & & & & & \\
\hline
\end{tabular}


Table A1. Cont.

\begin{tabular}{|c|c|c|c|c|c|c|c|c|c|c|c|c|c|c|c|c|c|c|c|c|c|c|c|c|}
\hline $\begin{array}{l}\text { Column Number } \\
\text { Ditassa sp.sg (Ep) }\end{array}$ & 1 & $\begin{array}{c}2 \\
20\end{array}$ & 3 & 4 & $\begin{array}{c}5 \\
33 \\
\end{array}$ & 6 & 7 & 8 & 9 & 10 & 11 & 12 & 13 & 14 & 15 & 16 & 17 & 18 & 19 & 20 & 21 & 22 & 23 & 24 \\
\hline Bacharis genistelloides (SS) & - & - & - & - & $\frac{53}{33}$ & - & - & - & - & - & - & - & - & - & - & - & - & - & - & - & - & - & - & - \\
\hline \multicolumn{25}{|c|}{ Viburno reticulati-Weinmannietum spruceanae ass. nov. } \\
\hline Viburnum reticulatum $(\mathbf{T})$ & - & - & - & - & - & $\frac{83}{6}$ & - & - & - & - & - & - & - & - & - & - & - & - & - & - & - & - & - & - \\
\hline $\begin{array}{l}\text { Pouzolzia poeppigiaina }(\mathrm{T}) \\
\text { Weinmannia sprucenana }(\mathrm{T})\end{array}$ & - & - & : & - & - & $\frac{50}{50}$ & - & - & - & - & - & - & - & - & - & - & - & - & - & - & - & - & - & - \\
\hline $\begin{array}{l}\text { Jatropha sp. (S) } \\
\text { Jorina (1) }\end{array}$ & - & - & - & 14 & - & $\frac{50}{50}$ & - & - & - & - & - & - & - & - & - & - & - & - & - & - & - & - & - & - \\
\hline Anthurium hamiltonii (H) & - & - & - & & - & $\underline{33}$ & - & - & - & - & - & - & - & - & - & - & - & - & - & - & - & - & - & - \\
\hline Mandevilla fragrans (C) & - & - & - & - & - & $\frac{33}{2}$ & - & - & - & - & - & - & - & - & - & - & - & - & & - & - & - & - & - \\
\hline Clusia crenata (T) & - & - & - & - & - & $\overline{33}$ & - & & - & - & - & - & & - & - & - & - & - & & - & - & - & - & - \\
\hline Pitcairnia paniculata $(\mathbf{H})$ & - & - & - & - & - & $\frac{\frac{5}{33}}{32}$ & - & - & - & - & - & - & - & - & - & - & - & - & - & - & - & - & - & - \\
\hline $\begin{array}{l}\text { Rubus urticifolius (S) } \\
\text { Gleichenella pectinata }(\mathbf{H})\end{array}$ & - & - & $=$ & 14 & - & $\frac{33}{33}$ & - & - & - & - & - & - & - & - & - & - & - & - & - & - & - & - & - & - \\
\hline \multicolumn{25}{|c|}{ Muntingia calabura-Hura crepitans community } \\
\hline Hura crepitans (T) & - & - & - & - & - & - & 100 & - & - & - & - & - & - & - & - & - & - & - & - & - & - & - & - & \\
\hline Ruellia brevifolia (S) & - & - & - & - & & - & 100 & - & - & - & - & - & - & - & & - & - & - & - & - & - & - & & - \\
\hline $\begin{array}{l}\text { Alliziai multiffora }(\mathbf{T}) \\
\text { Piper petatum }\end{array}$ & - & - & - & - & - & - & $\frac{100}{100}$ & - & - & - & - & - & - & - & - & - & - & - & - & - & - & - & - & - \\
\hline $\begin{array}{l}\text { Piper pertatum (H) } \\
\text { Piper nudilimbum (S) }\end{array}$ & - & - & - & - & : & - & 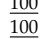 & 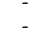 & : & - & : & - & 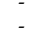 & : & - & - & - & - & : & - & - & : & - & - \\
\hline Ichnanthus nemorosus (H) & - & - & - & - & - & - & $\underline{100}$ & - & - & - & - & - & - & - & - & - & - & - & - & - & - & - & - & - \\
\hline Leucaena trichodes $(\mathbf{T})$ & - & - & - & - & & - & $\frac{100}{100}$ & - & - & - & - & - & - & - & - & - & - & - & - & - & - & - & - & - \\
\hline $\begin{array}{l}\text { Muntingia calabura (T) } \\
\text { Poullinia alata (C) }\end{array}$ & - & - & $\overline{29}$ & - & - & $\overline{17}$ & $\frac{100}{100}$ & - & - & - & - & - & - & - & - & - & - & - & - & - & - & $\begin{array}{c}- \\
100\end{array}$ & - & - \\
\hline \multicolumn{25}{|c|}{ Ахінаео піtidae-Podocarpetum oleifolii } \\
\hline Axinaea nitida (S) & - & - & - & - & - & - & - & $\underline{100}$ & $\underline{33}$ & - & - & - & - & - & $\underline{38}$ & $\underline{40}$ & - & - & - & - & - & - & - & - \\
\hline Podocarpus oleifolius (T) & - & - & - & - & - & - & - & 100 & $\overline{20}$ & - & - & - & - & - & - & & - & - & - & - & - & - & - & \\
\hline Trichilia tomentosa $\mathbf{( T )}$ & - & - & - & - & - & - & - & $\underline{100}$ & - & - & - & - & - & - & - & - & - & - & - & - & - & - & - & - \\
\hline Chrysophyllum & - & - & - & - & - & - & - & 60 & - & - & - & - & - & - & - & - & - & - & - & - & - & - & - & - \\
\hline $\begin{array}{l}\text { Contumazense (T) } \\
\text { Miconia firma (S) }\end{array}$ & - & - & . & - & - & - & - & $\overline{40}$ & - & - & - & - & - & - & - & - & - & . & . & . & . & . & . & . \\
\hline Viola argute (C) & - & - & - & - & - & - & - & $\frac{\underline{40}}{40}$ & - & - & - & - & - & - & - & - & - & - & - & - & - & - & - & - \\
\hline \multicolumn{25}{|c|}{ Verbesino auriculigerae-Siparunetum muricatae } \\
\hline Siparuna muricata $(\mathbf{T})$ & - & - & - & - & - & - & - & $\underline{40}$ & 100 & 100 & & - & & - & 25 & - & - & - & $\underline{33}$ & $\underline{50}$ & - & - & - & - \\
\hline Verbesina auriculigera (S) & - & - & - & - & - & - & - & $\overline{-}$ & 100 & $\underline{40}$ & 25 & - & 100 & & - & - & - & - & - & - & - & - & - & - \\
\hline Cervantesia tomentosa $(\mathrm{T})$ & - & - & - & - & - & - & - & - & $\frac{67}{2}$ & - & - & - & - & - & - & - & - & - & - & - & - & - & - & - \\
\hline Meliosma frondosa (T) & - & - & - & - & - & - & - & - & $\frac{33}{2}$ & - & $=$ & - & - & - & - & - & - & - & - & - & - & - & - & - \\
\hline 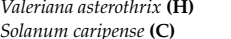 & - & - & - & - & - & - & - & - & $\frac{33}{33}$ & $\begin{array}{l}20 \\
20\end{array}$ & 25 & - & - & - & - & - & - & - & - & - & - & - & - & - \\
\hline Calceolaria calycina (S) & - & - & - & - & - & 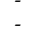 & - & - & $\frac{\frac{50}{33}}{33}$ & 20 & - & - & - & - & - & - & - & - & - & - & - & - & - & - \\
\hline Piper barbatum (C) & - & - & $=$ & - & - & - & - & - & $\frac{\frac{35}{33}}{33}$ & - & - & 29 & - & - & 13 & - & - & - & - & - & - & - & - & - \\
\hline Berberis buceronis (S) & - & - & - & - & - & - & - & - & $\frac{\frac{50}{33}}{32}$ & - & - & - & - & - & - & - & - & - & - & - & - & - & - & - \\
\hline Munnozia ferreyrii (H) & - & - & - & - & & - & - & - & $\frac{50}{67}$ & - & - & - & - & - & - & - & - & - & - & - & - & - & - & - \\
\hline Pappobolus sp._cjus8 (S) & - & - & - & - & - & - & - & - & $\underline{33}$ & - & - & - & - & - & - & - & - & - & - & - & - & - & - & - \\
\hline Phenax laxifforus (S) & - & - & - & - & - & - & - & - & $\frac{33}{23}$ & - & - & - & - & - & - & - & - & - & - & - & - & - & - & - \\
\hline $\begin{array}{l}\text { Lepechinia lamiifolia (S) } \\
\text { Setios }\end{array}$ & - & - & - & - & - & - & - & - & $\frac{\overline{33}}{32}$ & - & - & - & - & - & - & - & - & - & - & - & - & - & - & - \\
\hline $\begin{array}{l}\text { Scutia spicata (S) } \\
\text { Sinphompulus }\end{array}$ & - & - & - & - & - & - & - & - & $\underline{33}$ & - & - & - & - & - & - & - & - & - & - & - & - & - & - & - \\
\hline $\begin{array}{l}\text { Siphocampylus } \\
\text { macropoddides (S) }\end{array}$ & - & - & - & - & - & - & - & - & $\underline{33}$ & - & - & - & - & - & - & - & - & - & - & - & - & - & - & - \\
\hline 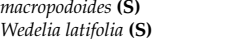 & & - & - & - & & - & - & - & 33 & - & - & - & - & - & & - & - & - & - & - & - & - & - & - \\
\hline Symplocos sandemanii (S) & - & - & - & - & - & - & - & - & $\underline{33}$ & - & - & - & - & - & - & - & - & - & - & - & - & - & - & - \\
\hline Fabaceae_cjvs6 (T) & - & - & - & - & - & - & - & - & $\underline{33}$ & - & - & - & - & - & - & - & - & - & - & - & - & - & - & - \\
\hline Begonia acerifolia $(\mathrm{H})$ & - & - & - & - & - & - & - & - & $\frac{50}{33}$ & - & - & - & - & - & - & - & - & - & - & - & - & - & - & - \\
\hline Rubus sp._civs6 (S) & - & - & - & - & - & - & - & - & $\frac{\overline{33}}{20}$ & - & - & - & - & - & - & - & - & - & - & - & - & - & - & - \\
\hline Luffa operculata (C) & - & - & - & - & - & - & - & - & $\frac{33}{23}$ & - & 25 & - & - & - & - & - & - & - & - & - & - & - & - & - \\
\hline $\begin{array}{l}\text { Mikania sp.ccivs6 (C) } \\
\text { Paspalum candidum (H) }\end{array}$ & - & - & - & - & - & - & - & - & $\frac{\overline{33}}{33}$ & - & $\begin{array}{c}- \\
25\end{array}$ & - & - & - & - & - & - & - & - & - & - & - & - & - \\
\hline
\end{tabular}


Table A1. Cont.

\begin{tabular}{|c|c|c|c|c|c|c|c|c|c|c|c|c|c|c|c|c|c|c|c|c|c|c|c|c|}
\hline Column Number & 1 & 2 & 3 & 4 & 5 & 6 & 7 & 8 & 9 & 10 & 11 & 12 & 13 & 14 & 15 & 16 & 17 & 18 & 19 & 20 & 21 & 22 & 23 & 24 \\
\hline \multicolumn{25}{|c|}{ Berberido beauverdianae-Myrcianthetum myrsinoidis } \\
\hline Maytenus boarioides (S) & - & - & - & - & - & - & - & - & - & $\frac{80}{9}$ & - & - & - & - & - & - & - & - & - & - & - & - & - & - \\
\hline Viburnum mathewsii (T) & - & - & - & - & - & - & - & - & - & $\frac{60}{10}$ & - & - & - & - & - & - & - & - & - & - & - & - & - & - \\
\hline $\begin{array}{l}\begin{array}{l}\text { Bidens squarrosa }(\mathrm{H}) \\
\text { Bomarea cornuta }(\mathrm{C})\end{array}\end{array}$ & 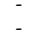 & 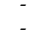 & $\therefore$ & - & - & 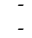 & - & 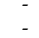 & $\therefore$ & $\frac{40}{40}$ & - & $\therefore$ & $\therefore$ & - & $\therefore$ & - & - & :- & $\therefore$ & $\therefore$ & 20 & 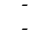 & $\therefore$ & $\because$ \\
\hline Tecoma stans $(\mathbf{T})$ & - & - & - & - & - & - & & 20 & - & $\frac{40}{40}$ & - & - & - & - & - & - & - & - & - & - & - & - & - & \\
\hline Salvia oppositiflora (S) & - & - & - & - & & - & - & - & - & $\underline{40}$ & 25 & - & - & - & - & - & & - & - & - & - & - & - & - \\
\hline Liabum solidagineum (S) & - & - & - & :- & : & :- & :- & 20 & - & $\frac{60}{40}$ & - & - & - & - & - & - & - & - & - & - & - & - & - & - \\
\hline \multicolumn{25}{|c|}{ Aristeguietio discoloris-Kageneckietum lanceolatae } \\
\hline Kageneckia lanceolata $(\mathrm{T})$ & - & - & - & - & - & - & - & - & - & - & 100 & - & - & - & - & - & - & - & - & - & - & - & - & - \\
\hline Aristeguietia discolor (S) & - & - & - & - & - & - & - & - & - & - & $\frac{100}{100}$ & - & - & - & - & - & - & - & - & - & - & - & - & - \\
\hline Baccharis emarginata (S) & - & - & - & - & - & - & - & - & - & - & 100 & - & - & - & - & - & - & - & - & - & - & - & - & \\
\hline Calceolaria rugulosa (S) & - & - & - & - & - & - & - & - & - & - & $\overline{100}$ & - & - & - & - & - & - & - & - & - & - & - & - & - \\
\hline Colletia spinosissima (S) & - & - & - & - & - & - & - & - & - & - & 100 & - & - & - & - & - & - & - & - & - & - & - & - & - \\
\hline $\begin{array}{l}\text { Cronquistianthus urubambensis } \\
\text { (S) }\end{array}$ & - & - & - & 14 & - & - & - & - & - & - & $\underline{100}$ & - & - & - & - & . & - & - & - & - & - & - & - & . \\
\hline Coreopsis fasciculate (SS) & - & - & - & - & - & - & - & - & - & - & $\overline{75}$ & - & - & - & - & - & - & - & - & - & - & - & - & - \\
\hline Scutellaria scutellarioides (SS) & - & - & - & - & - & - & - & - & - & - & $\frac{50}{50}$ & - & - & - & - & - & - & - & - & - & - & - & - & - \\
\hline $\begin{array}{l}\text { Passifflora peduncularis }(\mathbf{C}) \\
\text { Eryngium weberbaueri }(\mathbf{H})\end{array}$ & :- & - & :- & - & :- & - & :- & :- & :- & - & $\frac{50}{50}$ & - & :- & - & - & - & - & :- & :- & - & :- & :- & :- & - \\
\hline \multicolumn{25}{|c|}{ Baccharito latifoliae-Monactinetum flaverioidis } \\
\hline Passiffora tarminiana (C) & - & - & - & - & - & - & - & - & - & - & - & 57 & - & - & - & - & - & - & - & - & - & - & - & - \\
\hline Salvia alborosea (S) & - & - & - & - & - & - & - & - & - & - & - & $\frac{37}{57}$ & - & - & - & 20 & - & - & - & - & - & - & - & - \\
\hline 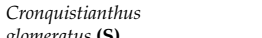 & - & - & - & - & - & - & - & - & - & - & - & $\underline{43}$ & - & - & - & - & - & - & - & - & - & - & - & - \\
\hline Calceolaria bicrenata (S) & - & - & - & - & - & - & - & - & - & - & - & $\underline{43}$ & - & - & - & - & - & - & - & - & - & - & - & . \\
\hline Minthostachys mollis (S) & - & 20 & - & - & - & - & - & - & - & - & - & $\frac{50}{43}$ & - & - & - & - & - & - & - & - & - & - & - & - \\
\hline \multicolumn{25}{|c|}{ Monactino flaverioidis-Colignonietum parviflorae } \\
\hline Colignonia parviftora (S) & - & - & - & - & - & - & - & - & - & - & - & - & $\frac{100}{00}$ & - & - & - & - & - & - & - & - & - & - & - \\
\hline Alternanthera villosa $(\mathbf{H})$ & - & - & - & - & - & - & - & - & - & 20 & - & - & $\frac{100}{60}$ & - & - & - & - & - & - & - & - & - & - & - \\
\hline Heliotropium incanum $(\mathbf{H})$ & - & - & - & - & - & - & - & - & - & - & - & - & $\frac{50}{50}$ & - & - & - & - & - & - & - & - & - & - & - \\
\hline $\begin{array}{l}\text { Urtica peruviana }(\mathbf{H}) \\
\text { Viguiera procumbens (S) }\end{array}$ & - & - & - & - & - & - & - & 20 & - & - & $\begin{array}{l}- \\
25\end{array}$ & is & $\frac{50}{50}$ & - & - & - & - & - & - & - & - & - & - & - \\
\hline \multicolumn{25}{|c|}{ Oenocarpo maporae-Mauritietum flexuosae } \\
\hline Oenocarpus mapora (T) & - & - & - & - & - & - & - & - & - & - & - & - & - & 100 & - & - & - & - & - & - & - & - & - & - \\
\hline Mauritia flexuosa $(\mathrm{T})$ & - & - & - & - & & - & - & - & - & - & - & - & - & $\frac{100}{100}$ & - & - & & - & - & - & - & - & - & - \\
\hline Buchenavia oxycarpa (T) & - & - & - & - & - & - & - & - & - & - & - & - & - & $\underline{100}$ & - & - & - & - & - & - & - & - & - & - \\
\hline $\begin{array}{l}\text { Ficus americana subsp. } \\
\text { ouingencis (T) }\end{array}$ & - & - & - & - & & - & - & - & - & - & - & - & - & $\underline{100}$ & - & - & & - & - & - & - & - & - & - \\
\hline Dialium guianense (T) & - & - & - & - & - & - & - & - & - & - & - & - & - & 100 & - & - & - & - & - & - & - & - & - & - \\
\hline 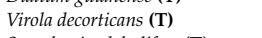 & - & - & - & - & - & - & - & - & - & - & - & - & - & $\frac{100}{100}$ & - & - & - & - & - & - & - & - & - & - \\
\hline $\begin{array}{l}\text { Sirota decorticansh (1) } \\
\text { Symphonia llobulifera }\end{array}$ & - & - & 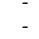 & $=$ & :- & $=$ & $\because$ & 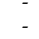 & 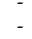 & - & 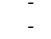 & - & $=$ & $\frac{100}{100}$ & - & 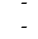 & - & :- & - & 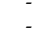 & 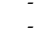 & - & $\because$ & - \\
\hline Geonoma macrostachys (S) & - & - & - & - & - & - & - & - & - & - & - & - & - & 100 & - & & - & - & - & - & - & & - & - \\
\hline Rinorea racemosa (S) & - & - & - & - & - & - & - & - & - & - & - & - & - & 100 & - & - & - & - & - & - & - & - & - & - \\
\hline Agonandra sylvatica (T) & - & - & - & - & - & - & - & - & - & - & - & - & - & $\frac{100}{100}$ & - & - & - & - & - & - & - & - & - & - \\
\hline Planchonella obovata (T) & - & - & - & - & - & - & - & - & - & - & - & - & - & $\frac{100}{100}$ & - & - & - & - & - & - & - & - & - & - \\
\hline Duguetia quitarensis (T) & - & - & - & - & - & - & - & - & - & - & - & - & - & $\frac{100}{100}$ & - & - & - & - & - & - & - & - & - & - \\
\hline Bactris concinna (S) & - & - & - & - & - & - & - & - & - & - & - & - & - & $\frac{100}{100}$ & - & - & - & - & - & - & - & - & - & - \\
\hline Ingasp. 01_jhom11 (T) & - & - & - & - & - & - & - & - & - & - & - & - & - & $\frac{50}{50}$ & - & - & - & - & - & - & - & - & - & - \\
\hline Costus scaber $(\mathbf{H})$ & - & - & - & - & - & - & - & - & - & - & - & - & - & $\frac{50}{50}$ & - & - & - & - & - & - & - & - & - & - \\
\hline $\begin{array}{l}\text { Virola calophylla (S) } \\
\text { Cegiborentandr (T) }\end{array}$ & - & - & - & - & - & - & - & - & - & - & - & - & - & $\frac{50}{50}$ & - & - & - & - & - & - & - & - & - & - \\
\hline $\begin{array}{l}\text { Ceiba a pentandrara }(\mathbf{T}) \\
\text { Anthurivum apaporanum }(\mathrm{H})\end{array}$ & :- & :- & :- & :- & 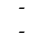 & :- & :- & : & :- & :- & :- & :- & : & $\frac{50}{50}$ & :- & :- & :- & :- & :- & :- & :- & :- & :- & : \\
\hline 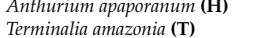 & - & - & - & - & - & - & - & - & - & - & - & & - & $\frac{50}{50}$ & - & - & - & - & 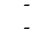 & :- & - & - & - & 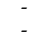 \\
\hline Chrysobalanacean__hom11 (T) & - & - & $=$ & $=$ & - & - & - & - & - & - & - & - & - & $\frac{50}{50}$ & - & - & - & - & - & - & - & - & - & - \\
\hline Euterpe precatoria (T) & - & - & - & - & - & - & - & - & - & - & - & - & - & $\underline{50}$ & - & - & - & - & - & - & - & - & - & - \\
\hline
\end{tabular}


Table A1. Cont.

\begin{tabular}{|c|c|c|c|c|c|c|c|c|c|c|c|c|c|c|c|c|c|c|c|c|c|c|c|c|}
\hline $\begin{array}{l}\text { Column Number } \\
\text { Hevea guianensis (T) }\end{array}$ & 1 & 2 & 3 & 4 & 5 & 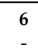 & 7 & 8 & 9 & 10 & 11 & 12 & 13 & $\begin{array}{l}14 \\
50\end{array}$ & 15 & 16 & 17 & 18 & 19 & 20 & 21 & 22 & 23 & 24 \\
\hline Socratea exorrhiza (T) & - & - & - & - & - & - & - & - & - & - & & - & - & $\underline{50}$ & - & - & - & - & - & - & - & - & - & - \\
\hline \multicolumn{25}{|c|}{ Hypolepido parallelogrammae-Alnetum acuminatae ass. nov. } \\
\hline Cyathea herzogii (T) & - & - & - & - & - & - & - & - & - & - & - & - & - & - & $\underline{50}$ & - & - & - & - & - & - & - & - & - \\
\hline $\begin{array}{l}\text { Hypolepis } \\
\text { parallelogramma }(\mathbf{H})\end{array}$ & - & - & - & - & & 17 & - & - & - & - & - & - & - & - & $\underline{63}$ & - & & - & - & - & - & - & - & - \\
\hline Hypolepis obtusata (H) & - & - & - & - & - & - & - & - & - & - & - & - & - & - & $\underline{50}$ & - & - & - & - & - & - & - & - & - \\
\hline Aulonemia longiaristata $(\mathrm{H})$ & - & - & - & - & - & - & - & - & - & - & - & - & - & - & $\underline{38}$ & - & - & - & - & - & - & - & - & - \\
\hline Miconia aff asperrima (S) & - & - & - & - & & - & - & - & - & & - & - & - & - & $\frac{38}{28}$ & - & & - & - & - & - & - & - & - \\
\hline Gurania sp. 01_cut (T) & - & - & - & - & - & - & - & - & - & - & - & - & - & - & $\frac{\overline{38}}{28}$ & - & - & - & - & - & - & - & - & - \\
\hline Solanum sp. 02_cut (S) & - & - & - & - & - & - & - & - & - & - & - & - & - & - & $\frac{\overline{38}}{20}$ & & - & - & - & - & - & - & - & - \\
\hline Acanthus ilicifolius (S) & - & - & - & - & - & - & - & - & - & - & - & - & - & - & $\frac{38}{28}$ & - & - & - & - & - & - & - & - & - \\
\hline Inga acuminata $(\mathrm{T})$ & - & :- & - & - & - & - & - & - & - & - & - & - & - & - & $\frac{38}{28}$ & - & - & - & - & - & - & - & - & - \\
\hline & - & 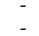 & $\therefore$ & - & - & - & 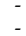 & - & - & - & - & :- & - & - & $\frac{38}{38}$ & - & - & - & - & - & - & - & - & - \\
\hline $\begin{array}{l}\text { Hediysmum sprucei }(\mathbf{S}) \\
\text { Miconia ag areragat } \mathbf{S}\end{array}$ & - & - & - & - & - & - & - & - & - & - & - & - & - & - & $\frac{38}{38}$ & :- & - & - & - & - & - & - & - & - \\
\hline $\begin{array}{l}\text { Miccona aggrergagat (S) } \\
\text { Asplenium auriculatum }(\mathbf{H})\end{array}$ & - & - & - & - & - & - & - & - & - & - & - & 14 & - & - & $\frac{50}{38}$ & - & - & - & - & - & - & - & - & :- \\
\hline Cyathea lechleri (T) & - & - & - & - & - & - & - & - & - & - & - & - & - & - & $\frac{50}{38}$ & - & - & - & - & - & 20 & - & - & - \\
\hline Geonoma orbignyana (S) & - & - & - & - & - & - & - & - & - & - & - & - & - & - & $\frac{38}{28}$ & - & - & - & - & - & - & - & - & - \\
\hline $\begin{array}{l}\text { Saccoloma inaequale }(\mathbf{H}) \\
\text { Serpocaulon fraxinifolium }(\mathbf{H})\end{array}$ & - & - & - & - & - & - & - & - & - & - & - & - & - & - & $\frac{38}{38}$ & 50 & - & - & - & - & - & - & - & - \\
\hline \multicolumn{25}{|c|}{ Lueheo divaricatae-Ceroxylonetum peruviani ass. nov. } \\
\hline Luehea divaricata (T) & - & - & - & - & - & - & - & - & - & - & - & - & - & - & - & 100 & - & - & - & - & - & - & - & - \\
\hline Ceroxylon peruvianum $(\mathbf{T})$ & & & & - & - & - & - & - & - & - & - & - & - & - & - & 100 & - & - & - & - & - & - & - & - \\
\hline Styloceras laurifolium (S) & - & - & - & - & - & - & - & - & - & - & - & - & - & - & - & 80 & - & - & - & - & - & - & - & - \\
\hline Pueraria phaseoloides (C) & - & - & - & - & & - & - & - & - & & - & - & - & - & - & $\underline{60}$ & & - & - & - & - & - & - & - \\
\hline Solanum sp. 03 (S) & - & - & - & - & - & 17 & - & - & - & - & - & 14 & - & - & 13 & $\underline{60}$ & - & - & - & - & - & - & - & - \\
\hline $\begin{array}{l}\text { Austroeupatorium } \\
\text { inulaefolium (S) }\end{array}$ & - & - & - & - & - & - & - & - & - & - & - & - & - & - & - & $\underline{40}$ & - & - & - & - & - & - & - & - \\
\hline 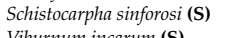 & - & - & - & - & - & - & - & - & - & - & - & - & - & - & 13 & $\frac{40}{40}$ & - & - & - & - & - & - & - & - \\
\hline $\begin{array}{l}\text { Viburnum incarum }(\mathbf{S}) \\
\text { Ladenbergia oblongifolia }(\mathrm{T})\end{array}$ & - & - & - & - & - & - & - & - & - & - & - & - & - & - & $\begin{array}{l}13 \\
-\end{array}$ & $\frac{\overline{40}}{40}$ & - & - & - & $\overline{17}$ & - & - & $\begin{array}{c}- \\
25\end{array}$ & - \\
\hline \multicolumn{25}{|c|}{ Mutisio wurdacki-Alnetum acuminatae ass. nov. } \\
\hline Mutisia wurdackii (C) & - & - & - & - & - & - & - & - & - & - & - & - & - & - & - & - & $\underline{100}$ & 25 & - & - & - & - & - & - \\
\hline Weinmannia costulata (S) & - & - & - & - & - & - & - & - & - & - & - & - & - & - & - & - & $\frac{\overline{100}}{50}$ & - & - & - & - & - & - & - \\
\hline Cortaderia jubata $\mathbf{( H )}$ & - & - & & - & - & - & - & - & - & & & & - & - & - & - & $\underline{50}$ & - & - & - & - & - & - & - \\
\hline \multicolumn{25}{|c|}{ Axinaeo tomentosae-Ceroxylonetum quindiuensis ass. nov. } \\
\hline Ceroxylon quindiuense (T) & - & - & - & - & - & - & - & - & - & - & - & - & - & - & - & - & - & $\frac{100}{10}$ & - & - & - & - & - & - \\
\hline $\begin{array}{l}\text { Cedrela odorata }(\mathbf{T}) \\
\text { Axinaea tomentosa }(\mathbf{S})\end{array}$ & - & - & - & - & - & - & - & - & - & - & - & - & - & - & $\begin{array}{c}25 \\
-\end{array}$ & - & - & $\frac{100}{75}$ & :- & :- & :- & :- & :- & 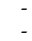 \\
\hline $\begin{array}{l}\text { Cronquistianthus } \\
\text { chachanosis (S) }\end{array}$ & - & - & - & - & - & - & - & - & - & - & - & - & - & - & 13 & 20 & - & $\underline{75}$ & - & - & - & - & - & . \\
\hline $\begin{array}{l}\text { chachapoyensis (S) } \\
\text { Citronella incarum (T) }\end{array}$ & - & - & - & - & - & - & - & - & & - & - & - & - & - & - & & - & 50 & - & - & - & - & - & - \\
\hline Vismia pozuzoensis (T) & - & - & - & - & - & - & - & - & - & - & - & - & - & - & - & - & - & $\underline{50}$ & - & - & - & - & - & - \\
\hline Erythrina aff edulis (T) & - & - & - & - & - & - & - & - & - & - & - & - & - & - & - & - & - & 50 & - & - & - & - & - & - \\
\hline Solanum barbulatum (S) & - & - & - & - & - & - & - & - & - & - & - & - & - & - & - & - & - & $\frac{50}{50}$ & - & - & - & - & - & - \\
\hline 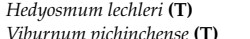 & - & - & - & - & - & - & :- & - & - & - & - & - & 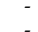 & - & - & - & - & $\frac{50}{50}$ & - & - & 20 & - & - & - \\
\hline $\begin{array}{l}\text { Vilururum pichinchense }(\mathbf{T}) \\
\text { Cornus peruviana }(\mathbf{S})\end{array}$ & - & $\therefore$ & $\therefore$ & $\therefore$ & - & 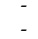 & $\because$ & $\because$ & - & - & - & $\therefore$ & 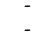 & $\because$ & - & $\therefore$ & - & $\frac{50}{50}$ & $\therefore$ & $\therefore$ & $\therefore$ & - & - & $\because$ \\
\hline \multicolumn{25}{|c|}{ Piperi chanchamayani-Cecropietum strigosae ass. nov. } \\
\hline Pennisetum & - & - & - & - & - & - & - & - & - & - & - & - & - & - & - & - & - & - & 100 & - & - & - & - & - \\
\hline $\begin{array}{l}\text { aff peruvininum (H) } \\
\text { Ageratita tambillensis (S) }\end{array}$ & - & - & - & - & . & - & ـ & - & - & - & - & - & . & ـ & - & _- & - & . & $\frac{100}{100}$ & 17 & 20 & ـ & ـ & . \\
\hline Solanum mite (S) & - & - & - & - & - & & - & - & & - & & - & - & - & - & & - & - & $\frac{67}{76}$ & - & - & & - & - \\
\hline Centropogon altus (S) & - & - & - & - & - & - & - & - & - & - & - & - & - & - & - & - & - & - & $\frac{67}{67}$ & - & - & - & - & - \\
\hline
\end{tabular}


Table A1. Cont.

\begin{tabular}{|c|c|c|c|c|c|c|c|c|c|c|c|c|c|c|c|c|c|c|c|c|c|c|c|c|}
\hline $\begin{array}{l}\text { Column Number } \\
\text { Cecropia strigose (T) }\end{array}$ & 1 & 2 & 3 & 4 & 5 & 6 & 7 & 8 & 9 & 10 & 11 & 12 & 13 & 14 & 15 & 16 & 17 & 18 & $\begin{array}{l}19 \\
67\end{array}$ & 20 & 21 & 22 & 23 & 24 \\
\hline $\begin{array}{l}\text { Clusia aff pallida (T) } \\
\text { (T) }\end{array}$ & - & - & - & - & - & - & - & - & - & - & - & - & - & - & - & - & - & - & $\frac{01}{67}$ & - & - & - & - & - \\
\hline Cavendishia punctate (S) & - & - & - & - & - & - & - & - & - & - & - & - & - & - & - & - & - & - & $\frac{\overline{33}}{22}$ & - & - & - & - & - \\
\hline Pilea aff bassleriana (S) & - & - & - & - & - & - & - & - & - & - & - & - & - & - & - & - & - & - & $\underline{33}$ & - & - & - & - & - \\
\hline Pilea pavonii (S) & - & - & - & - & - & - & - & - & - & - & - & - & - & - & - & & - & & $\frac{\overline{33}}{22}$ & - & - & & - & - \\
\hline Palicourea sp nov?sat2 (S) & - & - & - & - & - & - & - & - & - & - & - & - & - & - & - & - & - & - & $\underline{33}$ & - & - & - & - & - \\
\hline $\begin{array}{l}\text { Acinodendron } \\
\text { aff ferruineum }(\mathbf{S})\end{array}$ & - & - & - & - & - & - & - & - & - & - & - & - & - & - & - & & - & - & $\underline{33}$ & - & - & & - & - \\
\hline Thelypteris euchlora (H) & - & - & - & - & - & - & - & - & - & - & - & - & - & - & - & - & - & - & $\underline{33}$ & - & - & - & - & - \\
\hline Adianthum raddianum $(\mathbf{H})$ & - & - & - & - & - & - & - & - & - & - & - & - & - & - & - & & - & - & $\frac{53}{33}$ & - & - & - & - & - \\
\hline $\begin{array}{l}\text { Coriaria myrtifolia (S) } \\
\text { Solow }\end{array}$ & - & - & - & - & - & - & - & - & - & - & - & - & - & - & - & - & - & - & $\underline{33}$ & - & - & - & - & - \\
\hline Solanum asperolanatum (S) & - & - & - & - & - & - & - & - & - & - & - & - & - & - & - & - & - & 25 & $\underline{33}$ & - & - & - & - & - \\
\hline Miconia sanguinea (S) & - & - & - & - & - & - & - & - & - & - & - & - & - & - & - & - & - & - & $\underline{33}$ & 17 & - & - & - & - \\
\hline Canna paniculata $(\mathbf{H})$ & - & - & - & - & $\because$ & - & 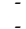 & 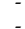 & - & - & - & - & - & - & - & - & - & - & $\underline{33}$ & 17 & - & - & - & - \\
\hline $\begin{array}{l}\text { Chromolaena leptocephala (S) } \\
\text { Micconia soo os sat (S) }\end{array}$ & - & $=$ & - & - & - & - & 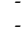 & $\because$ & - & - & - & - & - & - & - & - & - & - & $\frac{33}{22}$ & $-i$ & 20 & - & - & - \\
\hline $\begin{array}{l}\text { Miconia sp. o8__ast }(\mathbf{S}) \\
\text { Meriania tomentosa (S) }\end{array}$ & - & - & - & - & - & - & - & - & - & - & - & - & - & - & - & - & - & - & $\frac{33}{23}$ & 17 & - & - & - & - \\
\hline $\begin{array}{l}\text { Meriania tomentontos ( }) \\
\text { Pssmmisia coarctata (S) }\end{array}$ & & - & - & - & - & - & & - & . & - & - & - & - & - & - & - & - & - & $\frac{35}{3}$ & 20 & 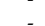 & 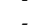 & 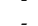 & - \\
\hline Anthurium grande $(\mathbf{H})$ & - & - & - & 29 & - & 17 & - & - & - & - & - & - & - & - & - & - & - & - & $\frac{53}{33}$ & - & - & - & - & - \\
\hline \multicolumn{25}{|c|}{ Cedrelo fissilis-Ficetum maximae ass. nov. } \\
\hline Ficus maxima $(\mathrm{T})$ & - & - & - & - & - & - & - & - & - & - & - & - & - & - & - & - & - & - & - & $\underline{100}$ & - & - & - & - \\
\hline Dieffenbachia sp. 02_sat $(\mathrm{H})$ & - & - & - & - & - & - & - & - & - & - & - & - & - & - & - & - & - & - & - & $\frac{83}{67}$ & - & - & - & - \\
\hline Dioscorea sp. 01_sat (C) & - & - & - & - & - & - & - & - & - & - & - & - & - & - & - & - & - & - & - & $\frac{\overline{67}}{67}$ & - & - & - & - \\
\hline Inga adenophylla (T) & - & - & - & - & - & - & - & - & - & - & - & - & - & - & - & - & - & - & - & $\frac{67}{4}$ & - & - & - & - \\
\hline Serjania communis (C) & - & - & - & :- & - & - & :- & - & - & - & & - & - & - & - & & - & - & - & $\frac{67}{67}$ & - & & - & - \\
\hline $\begin{array}{l}\text { Begonia parviffora (C) } \\
\text { Heliciniz }\end{array}$ & :- & 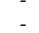 & - & - & - & 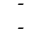 & : & - & - & - & - & - & - & - & 25 & 20 & - & - & - & $\frac{67}{67}$ & 20 & - & - & - \\
\hline $\begin{array}{l}\text { Helicionia sibulatata }(\mathbf{H}) \\
\text { Lastreopsis effuse }(\mathrm{H})\end{array}$ & - & - & - & - & & - & . & - & - & - & - & $=$ & - & $\therefore$ & - & 20 & - & - & 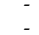 & $\frac{67}{67}$ & - & - & - & - \\
\hline $\begin{array}{l}\text { Lastrocopsls effise e (H) } \\
\text { Ocotea obovata }(\mathbf{T})\end{array}$ & - & - & - & - & - & - & - & - & - & - & - & - & - & - & - & - & _- & _- & - & $\frac{67}{50}$ & - & - & - & - \\
\hline Centropogon granulosus (C) & - & - & - & - & - & - & - & - & - & - & - & - & - & - & - & - & - & - & - & $\frac{50}{50}$ & - & - & - & - \\
\hline Philodendron aff killipii (Ep) & & - & - & - & - & - & - & - & - & - & - & - & - & - & - & - & - & - & - & 50 & - & - & - & - \\
\hline Selaginella trisulcata $(\mathrm{H})^{2}$ & - & - & - & - & - & - & - & - & - & - & - & - & - & - & - & - & - & - & - & $\underline{50}$ & - & - & - & - \\
\hline Croton lechheri $(\mathrm{T})$ & - & - & - & - & & - & - & - & - & & - & - & - & - & - & - & & - & - & $\underline{50}$ & - & - & - & - \\
\hline $\begin{array}{l}\text { Campyloneurum } \\
\text { ophicullon (1) }\end{array}$ & - & - & - & - & - & - & - & - & - & - & - & - & - & - & - & - & - & - & - & 50 & - & - & - & - \\
\hline Prestoea carderi (S) & - & - & - & - & - & - & - & - & - & - & - & - & - & - & - & - & - & - & - & 50 & 20 & - & - & - \\
\hline Vernonanthura patens (S) & - & - & - & - & - & - & - & - & - & - & - & - & - & - & & 20 & - & - & - & $\frac{50}{50}$ & - & - & & - \\
\hline $\begin{array}{l}\text { Urera baccifera }(\mathbf{S}) \\
\text { Alsophila mostllario }(\mathrm{T})\end{array}$ & - & :- & - & - & & - & - & - & - & - & - & - & - & - & 25 & - & & - & - & $\frac{50}{32}$ & - & - & 25 & - \\
\hline $\begin{array}{l}\text { Allsophita mostetlaria }(\mathbf{T}) \\
\text { Thelypteris jamesonnii }(\mathbf{H})\end{array}$ & - & : & :- & - & $\because$ & :- & 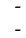 & $\because$ & 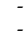 & - & - & - & :- & 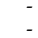 & - & - & - & :- & 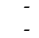 & $\frac{33}{33}$ & :- & - & 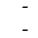 & - \\
\hline Melastomataceae 02_sat (S) & - & - & - & - & - & - & - & - & - & - & - & - & - & - & - & - & - & - & - & $\frac{50}{33}$ & - & - & - & - \\
\hline Thelypteris salzmannii (H) & - & - & - & - & - & - & - & - & - & - & - & - & - & - & - & - & - & - & - & $\underline{33}$ & - & - & - & - \\
\hline Costus sp. 02_sat $(\mathbf{H})$ & - & - & - & - & & - & - & - & - & - & - & - & - & - & - & - & & - & - & $\underline{33}$ & - & - & - & - \\
\hline Urera verrucosa (S) & - & - & - & - & - & - & - & - & - & - & - & - & - & - & - & - & - & - & - & $\frac{33}{27}$ & - & - & - & - \\
\hline Columnea inaquilatera $(\mathbf{H})$ & - & - & - & - & - & - & - & - & - & - & - & - & - & - & & - & - & - & - & $\frac{33}{22}$ & - & - & - & - \\
\hline Serpocaulon loriceum $(\mathbf{H})$ & - & - & - & - & - & & - & - & - & - & & - & - & - & 25 & - & - & 25 & - & $\frac{\overline{33}}{23}$ & - & & - & - \\
\hline Pteris altissima $\mathbf{( H )}$ & - & - & $\therefore$ & - & - & - & : & - & - & - & - & - & - & - & - & - & - & $=$ & - & $\frac{33}{33}$ & - & - & - & - \\
\hline $\begin{array}{l}\text { Nephrolepis pectinata (H) } \\
\text { Bignoniaceae (C) }\end{array}$ & - & - & - & - & - & - & - & : & - & - & - & - & - & - & - & 20 & - & - & - & $\frac{33}{33}$ & - & - & - & - \\
\hline \multicolumn{25}{|c|}{ Cecropio albicantis-Weinmannietum glomeratae ass. nov. } \\
\hline Cecropia albicans (T) & - & - & - & - & - & - & - & - & - & - & - & - & - & - & - & - & - & - & - & - & 60 & - & - & - \\
\hline Weinmannia latifolia $(\mathrm{T})$ & - & - & - & - & - & - & - & - & - & - & - & - & - & - & 13 & - & - & - & - & - & $\overline{60}$ & - & - & - \\
\hline Solanum aff sycophanta (S) & - & - & - & - & - & - & - & - & - & - & - & - & - & - & - & - & - & - & - & - & $\frac{60}{60}$ & - & - & - \\
\hline 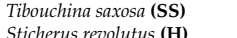 & - & - & - & - & - & - & - & - & - & - & - & - & - & - & - & - & - & - & - & - & $\frac{60}{60}$ & - & - & - \\
\hline $\begin{array}{l}\text { Sticherus revolutus (H) } \\
\text { Cagendishis nolbilis }\end{array}$ & - & - & : & - & - & - & - & - & - & - & - & - & - & - & - & - & :- & - & - & - & $\frac{60}{60}$ & - & - & - \\
\hline $\begin{array}{l}\text { Cavendishia nolbilili (S) } \\
\text { Piper ausustum (S) }\end{array}$ & :- & :- & : & :- & $\because$ & :- & 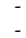 & $\because$ & $\because$ & 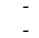 & :- & 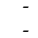 & :- & :- & 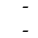 & :- & :- & :- & 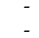 & 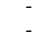 & $\frac{60}{40}$ & :- & 25 & 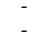 \\
\hline $\begin{array}{l}\text { Oreopanax } \\
\text { orffcheriophullus }(\mathrm{T})\end{array}$ & - & - & - & - & - & - & - & - & - & - & - & - & - & - & - & - & - & - & - & - & $\underline{40}$ & - & - & - \\
\hline $\begin{array}{l}\text { aff chererophy ylus (I) } \\
\text { Vaccinim crenatum (SS) }\end{array}$ & - & - & . & - & - & & . & . & - & - & - & - & - & . & - & - & - & - & - & - & $\underline{40}$ & - & - & - \\
\hline Miconia galactantha (S) & - & - & - & - & - & - & - & - & - & - & - & - & - & - & - & - & - & - & - & - & $\underline{\overline{40}}$ & - & - & - \\
\hline
\end{tabular}


Table A1. Cont.

\begin{tabular}{|c|c|c|c|c|c|c|c|c|c|c|c|c|c|c|c|c|c|c|c|c|c|c|c|c|}
\hline Column Number & 1 & 2 & 3 & 4 & 5 & 6 & 7 & 8 & 9 & 10 & 11 & 12 & 13 & 14 & 15 & 16 & 17 & 18 & 19 & 20 & 21 & 22 & 23 & 24 \\
\hline $\begin{array}{l}\text { Centropogon reffexus (C) } \\
\text { Dioscrean mitoensis (C) }\end{array}$ & : & - & :- & - & :- & :- & - & :- & : & - & :- & - & : & - & - & - & - & - & - & :- & $\frac{40}{40}$ & - & - & - \\
\hline Weinmannia auriculata $(\mathbf{T})$ & - & - & - & - & - & - & . & - & - & - & - & - & - & - & - & - & - & - & $=$ & - & $\frac{40}{40}$ & - & - & - \\
\hline Centropogon hirtus (S) & - & - & - & - & - & - & . & - & - & - & - & - & - & - & - & - & - & - & - & - & $\frac{40}{40}$ & - & - & - \\
\hline Ageratina rhytidodes (S) & - & - & - & - & - & - & - & - & - & - & - & - & - & - & - & - & - & - & - & - & $\underline{40}$ & - & - & - \\
\hline Thelypteris pachyrhachys $(\mathrm{H})$ & - & - & - & - & - & - & -1 & - & - & - & - & - & - & - & - & - & - & - & - & - & $\overline{40}$ & - & - & - \\
\hline Bomarea pseudopurpurea (C) & - & - & - & - & - & - & - & - & - & - & - & - & - & - & - & & - & - & - & - & $\underline{40}$ & & - & - \\
\hline Elleanthus aurantiacus $(\mathrm{H})$ & - & - & - & - & - & - & - & - & - & - & - & - & - & - & - & - & - & - & - & - & $\underline{40}$ & - & - & - \\
\hline 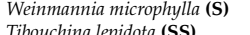 & 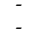 & - & $\because$ & 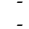 & - & 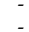 & . & - & - & - & - & - & - & - & - & - & - & - & - & - & $\frac{40}{40}$ & - & - & - \\
\hline Disterigma acuminatum (SS) & - & - & - & - & - & - & . & - & - & - & - & - & - & - & - & . & - & - & - & - & $\frac{ \pm 0}{40}$ & - & - & - \\
\hline \multicolumn{25}{|c|}{ Clusia trochiformis-Cecropia utcubambana community } \\
\hline Fuchsia macrophylla (S) & - & - & - & - & - & - & 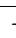 & - & - & - & - & - & - & - & - & - & - & - & - & - & 20 & 100 & - & - \\
\hline Serpocaulon adnatum (H) & - & - & - & - & - & - & - & - & - & - & - & - & - & - & & - & - & - & - & - & 20 & $\frac{100}{100}$ & 25 & - \\
\hline Barnadesia corymbosa (S) & - & - & - & - & - & - & . & - & - & - & - & - & - & - & 20 & - & - & - & - & - & - & $\frac{\overline{100}}{100}$ & - & - \\
\hline Ipomoea sp._tin_3 (C) & - & - & - & - & - & - & . & - & - & - & - & - & - & - & - & - & - & - & - & - & - & $\frac{100}{100}$ & - & - \\
\hline Anthurium sp._tin_3 (H) & - & - & - & - & - & - & - & - & - & - & - & - & - & - & - & - & - & - & - & - & - & $\frac{100}{100}$ & - & - \\
\hline Piper semicordulatum $(\mathbf{T})$ & : & - & $\because$ & $\because$ & 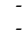 & - & . & - & - & - & - & - & - & - & - & - & - & - & - & - & - & $\frac{100}{100}$ & - & - \\
\hline 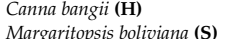 & - & - & - & - & - & - & . & - & - & - & - & - & - & - & $\because$ & - & - & - & - & - & - & $\frac{100}{100}$ & - & - \\
\hline Schefflera pentandra $(\mathbf{T})$ & . & - & - & - & & - & . & - & . & - & - & - & - & - & . & . & & - & - & . & . & $\frac{100}{100}$ & - & - \\
\hline Dryopteris patula $(\mathbf{H})$ & - & - & - & - & - & - & . & - & - & - & - & - & - & - & . & - & - & - & - & - & - & $\frac{100}{100}$ & 25 & - \\
\hline Palicourea angustifolia (S) & - & - & - & - & - & - & . & - & - & - & - & - & - & - & - & - & - & - & - & - & - & 100 & -3 & - \\
\hline \multicolumn{25}{|c|}{ Chelyocarpo ulei-Acacietum loretensis ass. nov. } \\
\hline Acacia loretensis (T) & - & - & - & - & - & - & - & - & - & - & - & - & - & - & - & - & - & - & - & - & - & - & 100 & - \\
\hline Chelyocarpus ulei (S) & - & - & - & - & - & - & - & - & - & - & - & - & - & - & - & - & - & - & - & - & - & - & 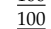 & - \\
\hline Miconia aff cremophylla (S) & - & - & - & - & - & - & - & - & - & - & - & - & - & - & - & - & - & - & - & - & - & - & 100 & - \\
\hline Selaginella haematodes (H) & - & - & - & - & - & - & - & - & - & - & - & - & - & - & - & - & - & - & - & - & - & - & 75 & - \\
\hline Acalypha stricta (S) & - & - & :- & 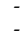 & - & :- & 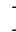 & - & - & - & - & - & - & - & - & - & - & - & - & - & - & - & $\underline{75}$ & - \\
\hline Banara guianensis $(\mathbf{T})$ & - & - & : & $\therefore$ & - & - & . & - & - & - & $=$ & - & - & - & - & - & - & - & - & - & 20 & - & $\underline{50}$ & - \\
\hline 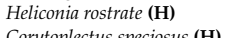 & - & - & 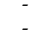 & $\therefore$ & - & - & . & - & - & - & - & - & - & - & - & - & - & - & - & - & - & - & 50 & - \\
\hline 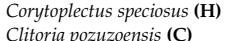 & - & $\therefore$ & $\because$ & $\because$ & $\because$ & - & 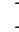 & - & $\because$ & - & - & - & - & $\because$ & $\therefore$ & - & - & - & - & - & - & - & 50 & - \\
\hline $\begin{array}{l}\text { Clitoria opzzzzeonsisi (C) } \\
\text { Sloanea ptariana }(\mathbf{T})\end{array}$ & - & - & - & . & - & & . & . & - & - & - & - & - & - & . & & - & - & - & - & . & & $\frac{30}{50}$ & - \\
\hline Thelypteris patens (H) & - & - & - & - & - & - & . & - & - & - & - & - & - & - & - & - & - & - & - & - & - & - & 50 & - \\
\hline Perebea angustifolia (T) & - & - & - & - & - & - & $-x^{-}$ & - & - & - & - & - & - & - & - & - & - & - & - & - & - & - & 50 & - \\
\hline Miconia amplexicaulis (S) & - & - & - & - & - & - & - & - & - & - & - & - & - & - & - & - & - & - & - & - & - & - & 50 & - \\
\hline Bauhinia tarapotensis (S) & - & - & :- & - & - & - & - & - & - & - & - & - & - & - & - & - & - & - & - & - & - & - & $\frac{50}{50}$ & - \\
\hline $\begin{array}{l}\text { Polybotrya caudata }(\mathbf{H}) \\
\text { Piper arboremu }(\mathbf{T})\end{array}$ & :- & 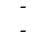 & : & $\therefore$ & - & - & & 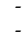 & $\therefore$ & - & - & - & - & - & - & - & - & - & - & - & - & - & $\frac{50}{50}$ & - \\
\hline $\begin{array}{l}\text { Piper rarboreum (1) } \\
\text { Paullinia serjanifolia (C) }\end{array}$ & - & - & - & . & - & & . & - & - & - & - & - & - & - & - & - & - & - & - & - & - & - & $\frac{30}{50}$ & - \\
\hline Boehmeria pavonii (S) & - & - & - & - & - & - & . & - & - & - & - & - & - & - & - & - & - & - & - & - & - & - & $\frac{0}{50}$ & - \\
\hline Tectaria antioquoiana $(\mathbf{H})$ & - & - & - & - & - & - & - & - & - & - & - & - & - & - & - & - & - & - & - & - & - & - & $\underline{50}$ & - \\
\hline \multicolumn{25}{|c|}{ Pachiro brevipedis-Euterpetum catingae } \\
\hline Mauritiella aculeata (T) & - & - & - & - & - & - & -3 & - & - & - & - & & - & - & - & - & - & - & - & - & - & - & - & 100 \\
\hline Caraipa utilis (S) & - & - & - & - & - & - & - & - & - & - & - & - & - & - & - & - & - & - & - & - & - & - & - & 100 \\
\hline Euterpe catinga $(\mathrm{T})$ & - & - & - & - & - & - & - & - & - & - & - & - & - & - & - & - & - & - & - & - & - & - & - & 100 \\
\hline Pachira brevipes $(\mathrm{T})$ & - & - & - & - & - & - & . & - & - & - & - & - & - & - & - & - & & - & - & - & - & - & - & $\underline{80}$ \\
\hline Doliocarpus major (C) & - & - & - & - & - & - & - & - & - & - & - & - & - & - & - & - & - & - & - & - & - & - & - & $\underline{70}$ \\
\hline 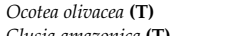 & - & - & - & - & - & - & - & - & - & - & - & - & - & - & - & - & - & - & - & - & - & - & $-{ }_{2}$ & $\frac{60}{60}$ \\
\hline Amaioua corymbosa (S) & - & - & - & - & - & . & . & . & - & - & - & - & - & - & - & . & - & - & - & 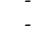 & - & - & -20 & $\frac{\frac{00}{60}}{60}$ \\
\hline Cathedra acuminata (T) & - & - & - & - & - & - & - & - & - & - & - & - & - & - & - & - & - & - & - & - & - & - & - & $\underline{50}$ \\
\hline $\begin{array}{l}\text { Chrysophyllum } \\
\text { houmbcum (T) }\end{array}$ & - & - & - & - & - & - & . & - & - & - & - & - & - & - & - & - & - & - & - & - & - & - & - & $\underline{50}$ \\
\hline $\begin{array}{l}\text { bombycinum }(\mathbf{T}) \\
\text { Mauritia carana }(\mathbf{T})\end{array}$ & - & . & . & . & - & & . & - & - & - & & - & . & . & - & & - & - & - & . & . & & _. & 40 \\
\hline Lindsaea divaricata (H) & - & - & - & - & - & - & - & - & - & - & - & - & - & - & - & - & - & - & - & - & - & - & - & $\frac{\overline{40}}{40}+x-3$ \\
\hline Vantanea parviffora $(\mathrm{T})$ & - & - & - & - & - & - & - & - & - & - & - & - & - & - & - & - & - & - & - & - & - & - & - & $\overline{30}$ \\
\hline
\end{tabular}


Table A1. Cont.

\begin{tabular}{|c|c|c|c|c|c|c|c|c|c|c|c|c|c|c|c|c|c|c|c|c|c|c|c|c|}
\hline Column Number & 1 & 2 & 3 & 4 & 5 & 6 & 7 & 8 & 9 & 10 & 11 & 12 & 13 & 14 & 15 & 16 & 17 & 18 & 19 & 20 & 21 & 22 & 23 & 24 \\
\hline \multicolumn{25}{|c|}{ SUPRATROPICAL RAINFORESTS FROM SOUTHERN PERU WITH POLYLEPIS (POLYLEPIDETEA TARAPACANO-BESSERI) } \\
\hline Bomarea ovata (C) & 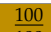 & & - & - & $\underline{33}$ & - & - & - & - & - & - & - & - & - & - & - & - & - & - & - & - & - & - & - \\
\hline Berberis peruviana (S) & $\frac{100}{100}$ & - & - & - & $\underline{33}$ & - & - & - & - & - & - & - & - & - & - & - & - & - & - & - & - & - & - & - \\
\hline \multirow{2}{*}{\multicolumn{25}{|c|}{ 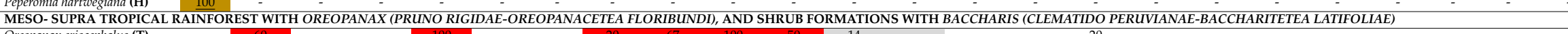 }} \\
\hline & & & & & & - & - & 20 & 67 & & 50 & & - & - & & 20 & & - & - & - & - & - & - & - \\
\hline Clematis haenkeana (C) & - & 40 & - & - & 14 & - & - & . & & $\frac{80}{10}$ & 25 & $\underline{43}$ & $\underline{50}$ & - & - & 20 & - & - & - & - & - & - & - & \\
\hline 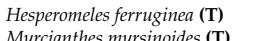 & - & - & - & - & 100 & - & - & & & $\frac{60}{100}$ & $\frac{50}{75}$ & - & - & - & 13 & - & - & - & - & - & - & - & - & - \\
\hline $\begin{array}{l}\text { Myrcianthes myrsinoides (T) } \\
\text { Mauria heterophylla (S) }\end{array}$ & - & - & - & - & - & 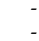 & :- & 20 & $\frac{33}{33}$ & $\frac{100}{80}$ & $\frac{75}{50}$ & :- & :- & :- & - & - & :- & :- & - & - & - & - & - & - \\
\hline Adiantum concinnum (H) & - & - & - & - & - & - & - & 20 & $\frac{67}{67}$ & $\frac{60}{60}$ & & - & - & - & - & 20 & - & - & - & - & - & - & - & - \\
\hline Oreocallis grandiflora (S) & - & - & - & - & - & - & - & 40 & & $\underline{60}$ & 25 & & - & - & - & - & - & - & - & - & - & - & - & - \\
\hline Vallea stipularis (S) & - & - & - & - & - & - & - & $\overline{20}$ & $\underline{33}$ & $=$ & & 29 & - & - & - & - & - & - & - & - & 20 & - & - & - \\
\hline Baccharis latifolia (S) & - & - & - & - & - & - & - & - & - & & 25 & $\underline{100}$ & $\underline{50}$ & - & - & - & & - & - & - & - & - & - & - \\
\hline Berberis beauverdiana (S) & - & - & - & - & - & - & - & & & $\underline{100}$ & & & $\underline{50}$ & - & - & - & - & - & - & - & - & - & - & - \\
\hline Delostoma integrifolium $(\mathbf{T})$ & - & - & - & - & - & - & - & $\underline{40}$ & $\underline{33}$ & - & & - & - & - & - & - & - & - & - & - & - & - & - & - \\
\hline 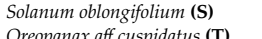 & - & - & - & - & : & - & - & $\frac{40}{20}$ & $\frac{33}{67}$ & - & 25 & : & - & - & - & - & - & $-\overline{2}$ & - & - & - & - & - & - \\
\hline $\begin{array}{l}\text { Oxalis peduncularis (C) } \\
\text { Ox) }\end{array}$ & - & - & - & - & - & - & 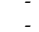 & & $\frac{\frac{w}{33}}{33}$ & 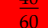 & & : & - & _. & - & _. & $\because$ & ${ }^{25}$ & - & - & $\therefore$ & - & - & $\therefore$ \\
\hline Salvia punctate (SS) & - & - & - & - & : & - & - & - & $\frac{35}{33}$ & $\underline{-}$ & $\underline{75}$ & - & - & - & - & - & & - & - & - & - & - & - & - \\
\hline Mutisia acuminata (C) & - & - & - & - & - & - & - & & $\frac{33}{n}$ & - & 25 & & & - & 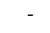 & - & - & - & - & & - & - & & \\
\hline Lupinus mutabilis (S) & - & - & - & - & - & - & - & & $\frac{50}{67}$ & & $\underline{50}$ & - & $\underline{50}$ & - & - & & - & - & - & - & - & & - & - \\
\hline Citharexylum flexuosum (S) & - & - & - & - & - & - & - & 60 & II & 80 & & & I & - & 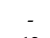 & - & 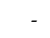 & - & - & - & - & - & - & \\
\hline Monactis flaverioides (S) & - & - & - & - & - & - & - & $=$ & $\underline{33}$ & $\frac{\overline{40}}{\underline{4}}$ & 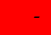 & $\underline{100}$ & 100 & - & 13 & - & - & - & - & - & - & - & - & - \\
\hline Prunus rigida $(\mathrm{T})$ & - & - & - & - & - & - & - & 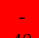 & & $\underline{\overline{80}}$ & & & $\underline{50}$ & - & - & - & - & - & - & - & - & - & - & - \\
\hline Clusia pseudomangle (S) & - & - & - & - & - & - & - & $\underline{40}$ & ก & 67 & & - & - & - & - & - & - & $\underline{50}$ & - & - & - & - & - & - \\
\hline Fuchsia ayavacensis (S) & - & - & - & - & - & - & - & in & $\frac{40}{33}$ & $\frac{67}{100}$ & & - & - & - & - & - & - & - & - & - & - & - & - & - \\
\hline $\begin{array}{l}\text { Monnina pilosa (S) } \\
\text { Lepechinin mollis (S) }\end{array}$ & :- & :- & : & :- & :- & - & - & 20 & $\frac{33}{-}$ & $\frac{100}{40}$ & $\frac{50}{50}$ & - & - & - & :- & 20 & - & - & - & - & - & - & - & - \\
\hline Otholobium munyense (S) & - & 20 & - & - & : & - & - & - & - & $\stackrel{\frac{40}{-}}{-}$ & $\frac{50}{25}$ & $\underline{43}$ & 100 & 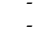 & $=$ & $=$ & - & - & - & - & - & 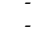 & - & - \\
\hline Hedyosmum scabrum $(\mathbf{T})$ & - & & & & & - & & 40 & $\underline{33}$ & & & & & - & 13 & 20 & & 25 & & & & & - & \\
\hline Miconia denticulate (S) & - & - & - & - & - & - & - & $\frac{100}{100}$ & 67 & 80 & - & - & - & - & - & - & - & - & - & - & - & - & - & - \\
\hline $\begin{array}{l}\text { Ilex uniflora (T) } \\
\text { (T) }\end{array}$ & - & - & - & - & & - & - & $\frac{150}{60}$ & $\frac{15}{67}$ & $\frac{20}{80}$ & & - & 50 & - & - & - & & - & - & - & - & - & - & - \\
\hline Aphelandra acanthifolia (S) & - & - & - & - & - & - & - & 40 & $\underline{33}$ & $\underline{60}$ & - & - & - & - & - & - & - & - & - & - & - & - & - & - \\
\hline $\begin{array}{l}\text { Cronquistianthus marrubiifolius } \\
\text { (S) }\end{array}$ & - & - & - & - & - & - & - & $\underline{40}$ & $\underline{33}$ & 80 & $\underline{75}$ & - & - & - & - & - & - & - & - & - & - & - & - & - \\
\hline Passiflora sagasteguii (C) & - & - & - & - & - & - & - & 60 & 33 & 80 & 75 & - & - & - & - & - & - & - & - & - & - & - & - & - \\
\hline $\begin{array}{l}\text { Clusia multiflora (T) } \\
\text { C) }\end{array}$ & - & - & - & - & - & - & - & $\frac{50}{40}$ & $\frac{50}{67}$ & $\frac{00}{80}$ & & - & - & - & 25 & & & - & 33 & - & - & - & - & - \\
\hline Myrsine latifolia (T) & - & - & - & - & & - & - & 40 & 33 & 100 & - & - & - & - & - & 20 & 100 & - & & - & - & - & - & - \\
\hline Croton abutiloides (S) & - & - & - & - & - & - & - & 20 & - & 60 & & - & - & - & - & 60 & - & - & - & - & - & - & - & - \\
\hline & & & & & & - & & 20 & & 40 & & - & $\underline{50}$ & - & - & & - & - & - & - & & & & \\
\hline \multicolumn{25}{|c|}{ THERMO-MESOTROPICAL FORESTS WITH ALNUS (ALNETEA ACUMINATAE) } \\
\hline Alnus acuminata (T) & & & & & & & - & - & - & - & - & - & - & - & 50 & 20 & 100 & 25 & - & - & 20 & - & - & \\
\hline Pteris deflexa $\mathbf{( H )}$ & - & - & - & - & - & - & - & - & - & - & - & - & - & - & $\frac{50}{50}$ & $\underline{40}$ & $\frac{100}{-}$ & 20 & - & - & - & - & - & - \\
\hline Escallonia pendula (T) & - & - & - & - & - & - & - & - & - & - & - & - & - & - & & $\frac{\frac{10}{100}}{100}$ & $\underline{50}$ & 25 & - & - & - & - & - & - \\
\hline Thelypteris pennata $(\mathbf{H})$ & - & - & - & - & & 17 & - & - & - & - & - & - & - & - & - & $\underline{60}$ & $=$ & $\underline{50}$ & - & - & - & - & - & - \\
\hline Pentacalia reflexa (S) & - & - & - & - & - & - & - & - & - & - & - & - & - & - & - & $=$ & $\frac{100}{100}$ & $\frac{75}{50}$ & - & - & - & - & - & - \\
\hline \multirow{2}{*}{\multicolumn{25}{|c|}{ POCAULO DASYPLEURONIS-ALCHORNEION LATIFOLIAE all. nov.) }} \\
\hline & & & & & & & & & & & & & & & & & & & & & & & & \\
\hline 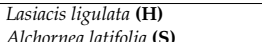 & - & :- & $\frac{71}{57}$ & 43 & - & - & - & - & - & - & - & - & - & - & - & - & - & - & - & - & - & $\underline{100}$ & 25 & \\
\hline $\begin{array}{l}\text { Alchornean latifolia (S) } \\
\text { Psschotria peepigiana (S) }\end{array}$ & - & - & $\frac{37}{43}$ & $\underline{40}$ & - & - & - & - & - & - & - & - & 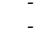 & - & - & - & - & - & - & - & - & - & - & - \\
\hline Serpocaulon dasypleuron (H) & - & - & $\frac{10}{80}$ & 71 & & . & - & . & - & - & - & - & . & . & - & - & - & - & - & - & . & - & - & . \\
\hline Lindsaea arcuata $(\mathbf{H})$ & - & 40 & - & 29 & - & 67 & - & - & - & - & - & - & - & - & - & - & - & - & - & - & - & - & - & - \\
\hline Cyathea delgadii (T) & - & & $\underline{86}$ & & - & - & - & - & - & - & - & - & - & - & 13 & - & - & - & 67 & - & - & - & - & - \\
\hline Olyra latifolia $(\mathbf{H})$ & - & - & $\frac{00}{86}$ & - & . & 50 & - & - & - & - & & & - & - & - & & - & - & $\frac{11}{-}$ & - & - & & - & - \\
\hline $\begin{array}{l}\text { Graffenrieda cucullata }(\mathrm{T}) \\
\text {. }\end{array}$ & - & - & $\underline{86}$ & 5 & - & 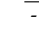 & - & - & - & - & - & - & - & - & 25 & - & - & - & $\underline{67}$ & $\underline{100}$ & $\underline{40}$ & - & - & - \\
\hline
\end{tabular}


Table A1. Cont.

\begin{tabular}{|c|c|c|c|c|c|c|c|c|c|c|c|c|c|c|c|c|c|c|c|c|c|c|c|c|}
\hline $\begin{array}{l}\text { Column Number } \\
\text { THERMO-INFRATROPICAI }\end{array}$ & $\frac{1}{\text { RAIN }}$ & $\frac{2}{2 \mathrm{EST}^{2}}$ & $\frac{3}{0 M N}$ & $\frac{4}{\text { [HER }}$ & $\frac{5}{\mathrm{RU}(P}$ & $\frac{6}{I D I C}$ & $\frac{7}{\text { ICAE- }}$ & $\frac{8}{-A T H E}$ & $\frac{9}{C A R}$ & $\frac{10}{4 N-1}$ & 11 & 12 & 13 & 14 & 15 & 16 & 17 & 18 & 19 & 20 & 21 & 22 & 23 & 24 \\
\hline Pteris cretica $(\mathrm{H})$ & - & $\frac{-}{15}$ & - & 14 & & 67 & 100 & & & & & & & & & & & & & & & & & \\
\hline Pennisetum peruvianum $(\mathbf{H})$ & - & - & - & - & - & 67 & - & - & - & - & - & - & - & - & - & - & - & 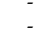 & - & - & - & 100 & - & - \\
\hline Cyrtocymura scorpioides (S) & - & - & - & - & - & $\frac{\overline{33}}{22}$ & $\therefore$ & - & - & - & - & - & - & - & - & - & - & - & $\underline{33}$ & - & - & - & - & - \\
\hline Fuchsia matherwsii (S) & - & - & - & - & - & $\frac{\overline{33}}{23}$ & $\underline{100}$ & - & - & - & - & - & - & - & - & - & - & - & $=$ & $-\overline{1}$ & - & $\therefore$ & - & - \\
\hline $\begin{array}{l}\text { Cecropia utcubambana }(\mathrm{T}) \\
\text { Seopmuni }\end{array}$ & - & - & - & - & - & $\frac{33}{33}$ & - & - & - & - & - & - & - & - & - & 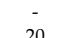 & - & - & - & 17 & - & $\underline{100}$ & $\underline{50}$ & - \\
\hline $\begin{array}{l}\text { Seemannia sylvatica (H) } \\
\text { Miconing }\end{array}$ & - & - & - & - & - & $\frac{33}{33}$ & - & - & - & - & - & - & - & - & - & 20 & - & $-\overline{0}$ & - & $\underline{33}$ & - & - & - & - \\
\hline $\begin{array}{l}\text { Miconia adinantha (S) } \\
\text { Bepoina pervyzinun (C) }\end{array}$ & - & - & - & :- & - & $\frac{33}{33}$ & - & $\underline{40}$ & :- & - & - & - & - & - & $-\dot{13}$ l & - & - & $\underline{50}$ & 67 & & - & - & - & - \\
\hline $\begin{array}{l}\text { Begonia peruviana (C) } \\
\text { Piper linentum (S) }\end{array}$ & 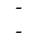 & 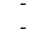 & 14 & & - & $\frac{33}{33}$ & - & - & - & - & : & :- & - & :- & 13 & 100 & :- & 25 & $\frac{67}{-}$ & $\frac{67}{-}$ & 20 & : & : & :- \\
\hline \multicolumn{25}{|c|}{$\begin{array}{l}\text { Tiper Ineantum (S) } \\
\text { MESO-TO INFRATROPICAL RAINFORESTS FROM CENTRAL PERU (SANCHEZIO OBLONGAE-HEDYOSMION RACEMOSAE all. nov.) }\end{array}$} \\
\hline Piper chanchamayanum (S) & - & - & - & - & & - & - & - & - & - & - & - & - & - & - & - & - & - & $\frac{100}{1}$ & $\frac{33}{7}$ & - & & & \\
\hline Zeugites americanus $(\mathbf{H})$ & - & - & - & - & - & - & - & - & - & - & - & - & - & - & - & - & & - & $\frac{67}{6}$ & $\overline{17}$ & - & $\underline{100}$ & - & - \\
\hline Miconia affinis (T) & - & - & - & - & - & - & - & - & - & - & :- & - & - & - & - & - & - & - & $\frac{33}{23}$ & $\frac{83}{82}$ & - & - & - & - \\
\hline Sanchezia oblonga (S) & - & - & - & :- & - & - & - & - & - & - & - & - & - & - & - & & - & - & $\frac{33}{32}$ & $\frac{83}{50}$ & - & 25 & - & - \\
\hline Geonoma stricta (S) & - & :- & - & - & - & - & - & - & - & - & - & 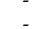 & - & - & - & - & - & - & $\frac{33}{22}$ & $\frac{50}{50}$ & - & - & - & - \\
\hline $\begin{array}{l}\text { Dennstaedtia aurriculatata } \mathbf{H}) \\
\text { Gurania lobate }(\mathbf{C}\end{array}$ & - & :- & - & - & - & - & 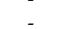 & - & - & - & - & - & - & - & - & - & - & - & $\frac{33}{33}$ & $\frac{50}{50}$ & - & - & - & - \\
\hline $\begin{array}{l}\text { Uuranaia lobate (C) } \\
\text { Anthurium aff amoenum }(\mathrm{H})\end{array}$ & - & - & - & - & - & _ & _. & - & - & - & - & - & - & - & - & - & - & - & $\frac{33}{33}$ & $\frac{50}{50}$ & - & - & - & - \\
\hline $\begin{array}{l}\text { Liabum nudicaule (S) } \\
\text { (1) }\end{array}$ & - & - & - & - & - & - & - & - & - & - & - & - & - & - & - & - & - & - & $\frac{33}{33}$ & $\frac{50}{50}$ & - & - & 25 & - \\
\hline Blepharodon salicinus (C) & - & - & - & - & - & - & - & - & - & - & - & - & - & - & - & - & - & - & $\frac{5}{33}$ & $\frac{50}{33}$ & - & - & - & - \\
\hline Weinmannia glomerata $(\mathbf{T})$ & - & - & - & - & - & - & - & - & - & - & - & - & - & - & - & - & - & - & $\underline{33}$ & & $\underline{80}$ & - & - & - \\
\hline $\begin{array}{l}\text { Baccharis decussata subsp. } \\
\text { jelskii (S) }\end{array}$ & - & - & - & - & & - & - & - & - & - & - & - & - & - & - & - & & - & $\underline{\underline{33}}$ & - & $\underline{60}$ & - & - & - \\
\hline Pilea haenkei (S) & - & - & - & - & & - & - & - & - & - & - & - & - & - & - & - & - & - & 33 & 17 & - & 100 & - & - \\
\hline Piper malifolium $(\mathbf{T})$ & - & - & - & - & & - & - & - & - & - & - & - & - & - & - & - & & - & $\underline{33}$ & 17 & - & $\underline{100}$ & - & - \\
\hline Passiffora rubra (C) & - & - & - & - & - & - & - & - & - & - & - & - & - & - & - & - & - & - & 33 & & 20 & - & $\frac{50}{25}$ & - \\
\hline Pteris podophylla $(\mathrm{H})$ & - & - & - & - & - & - & - & - & - & - & - & - & - & - & - & - & - & - & $\frac{100}{6}$ & $\frac{83}{22}$ & - & - & 25 & - \\
\hline $\begin{array}{l}\text { Fuchsia ovalis (S) } \\
\text { Hedrossumm racemosum } \\
\text { (T) }\end{array}$ & :- & : & 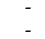 & $\therefore$ & :- & - & :- & :- & - & - & - & - & - & - & - & - & - & - & $\frac{67}{67}$ & $\frac{33}{83}$ & - & :- & $=$ & - \\
\hline Oreopanax polycephalus (T) & - & - & - & - & - & - & - & - & - & - & - & - & - & - & - & - & - & - & $\frac{01}{67}$ & $\frac{83}{50}$ & - & - & - & - \\
\hline Pteris quadriaurita $(\mathbf{H})$ & - & - & - & - & - & - & - & - & - & - & - & - & - & - & 25 & 20 & - & - & $\frac{53}{33}$ & & 40 & - & - & - \\
\hline Anthurium breviscapum $(\mathbf{H})$ & - & - & - & - & & - & - & - & - & - & - & - & - & - & - & - & & - & $\overline{67}$ & $\underline{100}$ & $\overline{20}$ & - & - & - \\
\hline Monstera obliqua (H) & - & - & - & - & - & - & - & - & - & - & - & - & - & - & - & & - & - & $\underline{33}$ & $\overline{17}$ & - & 100 & 25 & - \\
\hline Clusia trochiformis (S) & & & & - & & - & & & - & & - & & - & - & - & - & - & - & & 10 & $\underline{40}$ & $\overline{100}$ & & \\
\hline Miconia cyanocarpa (S) & - & - & - & - & - & - & - & - & - & - & & - & - & - & - & - & - & - & - & - & 80 & $\underline{100}$ & - & - \\
\hline Monnina marginata (S) & - & - & - & - & - & - & - & - & - & - & - & - & - & - & - & - & - & - & - & - & $\underline{40}$ & & $\underline{50}$ & - \\
\hline $\begin{array}{l}\text { Niphidium albopunctatissimum } \\
\text { (()) }\end{array}$ & - & - & - & - & - & & - & - & - & - & & - & - & - & - & & - & - & - & - & $\underline{40}$ & 100 & - & - \\
\hline Dryopteris wallichiana $(\mathbf{H})$ & - & - & - & - & - & - & - & - & - & - & - & - & - & - & - & - & - & 25 & - & - & 20 & $\underline{100}$ & & \\
\hline Cedrela fissilis (T) & - & - & - & - & - & - & - & - & - & - & - & - & - & - & - & - & - & - & - & 67 & - & $\frac{100}{-}$ & 25 & - \\
\hline Palicourea guianensis (S) & - & & - & - & - & - & - & - & - & - & - & - & - & - & - & - & - & - & 32 & $\frac{33}{23}$ & & - & $\frac{50}{50}$ & \\
\hline Iresine diffusa (C) & - & - & - & - & - & - & - & - & - & - & - & - & - & - & - & - & - & - & $\frac{33}{3}$ & $\frac{50}{33}$ & 20 & - & $\frac{\frac{}{50}}{\underline{*}}$ & - \\
\hline Diplazium tungurahuae $(\mathrm{H})$ & - & - & - & - & - & - & - & - & - & - & - & - & - & - & - & - & - & - & $\underline{\frac{53}{33}}$ & $\underline{\frac{5}{33}}$ & - & - & $\frac{55}{25}$ & - \\
\hline Inga semialata $(\mathbf{T})$ & - & - & - & 14 & - & - & - & - & - & - & - & - & - & - & - & - & - & - & - & - & - & - & 25 & $\underline{60}$ \\
\hline $\begin{array}{l}\text { Piper aduncum (S) } \\
\text { Ingra edulis (T) }\end{array}$ & - & - & - & 14 & - & - & - & - & - & - & - & - & - & - & - & - & - & - & - & - & - & - & $\frac{50}{75}$ & $=$ \\
\hline \multicolumn{25}{|c|}{ MESO- TO INFRATROPICAL MOUNTAIN RAINFORESTS FROM PERU (MORELLO PUBESCENTIS-MYRSINETEA CORIACEAE cl. nov) } \\
\hline Niphidium crassifolium $\mathbf{( H )}$ & - & 60 & 29 & 14 & & - & - & 20 & & 20 & - & & 50 & - & 50 & 20 & 100 & 50 & & 33 & & & & \\
\hline Blechnum occidentale $(\mathbf{H})$ & - & - & & & & - & - & 100 & 67 & 60 & - & - & - & - & & $\underline{40}$ & $\underline{50}$ & $\underline{\overline{75}}$ & 100 & $\underline{50}$ & $\overline{80}$ & 100 & $\underline{50}$ & - \\
\hline Pteridium arachnoideum $(\mathbf{H})$ & - & 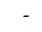 & - & 14 & $\underline{33}$ & $\underline{83}$ & & $\overline{60}$ & & $\underline{80}$ & - & - & - & - & 13 & $\underline{40}$ & & $\overline{25}$ & & $=$ & $\overline{20}$ & - & $=$ & - \\
\hline Baccharis inamoena (S) & - & $\underline{80}$ & - & - & $\underline{100}$ & $\underline{67}$ & $\underline{100}$ & & - & & - & & - & - & 13 & $\overline{20}$ & $\underline{100}$ & $\underline{100}$ & - & - & & - & - & - \\
\hline Ageratina sternbergiana (S) & - & $\frac{\overline{40}}{20}$ & - & - & - & $=$ & - & $\underline{40}$ & $\underline{33}$ & $\underline{60}$ & $\underline{100}$ & $\underline{43}$ & - & - & 25 & & $\underline{50}$ & - & - & - & & - & - & - \\
\hline Myriocarpa stipitata $(\mathbf{T})$ & - & 20 & - & 29 & - & 17 & $\underline{100}$ & & & & & & - & - & & $\frac{80}{6}$ & & - & $\underline{67}$ & - & - & - & $\underline{50}$ & - \\
\hline Tradescantia cymbispatha $\mathbf{( H )}$ & - & $\underline{40}$ & - & $\frac{43}{1}$ & - & 17 & - & 20 & - & - & - & - & - & - & 13 & $\underline{40}$ & - & $\underline{50}$ & - & - & - & $=$ & - & - \\
\hline Condaminea corymbosa (S) & - & - & - & 14 & & $\underline{50}$ & - & - & - & & - & - & - & - & $\frac{50}{6}$ & - & & - & 33 & 20 & $\frac{100}{0}$ & $\underline{75}$ & - & - \\
\hline 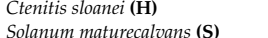 & :- & 60 & : & ${ }_{14}^{14}$ & 67 & - & :- & 40 & 33 & - & :- & :- & :- & - & $\frac{63}{-}$ & 20 & - & - & $\frac{100}{33}$ & 17 & $\frac{80}{-}$ & - & $\frac{50}{-}$ & :- \\
\hline $\begin{array}{l}\text { Solanum manuturecalvanss }(\mathbf{S}) \\
\text { Saurauia perviana }(\mathrm{T})\end{array}$ & - & $\underline{0}$ & - & 29 & $\frac{-}{-1}$ & - & - & $\underline{-10}$ & $\frac{\frac{35}{33}}{33}$ & - & - & - & - & - & & - & 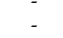 & 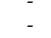 & $\frac{\frac{53}{33}}{33}$ & $\underline{50}$ & 20 & $\overline{100}$ & $\because$ & \\
\hline
\end{tabular}


Table A1. Cont.

\begin{tabular}{|c|c|c|c|c|c|c|c|c|c|c|c|c|c|c|c|c|c|c|c|c|c|c|c|c|}
\hline $\begin{array}{l}\text { Column Number } \\
\text { Cavendishia bracteata (S) }\end{array}$ & 1 & 2 & 3 & $\begin{array}{c}4 \\
14\end{array}$ & 5 & 6 & 7 & 8 & 9 & 10 & 11 & 12 & 13 & 14 & 15 & 16 & 17 & 18 & 19 & 20 & 21 & 22 & 23 & 24 \\
\hline Serpocaulon caceresii (H) & - & 80 & 57 & 14 & - & 17 & - & - & - & - & - & - & - & - & 20 & - & - & - & $\frac{33}{-}$ & 17 & ${ }^{20}$ & - & - & - \\
\hline Siparuna aspera (S) & - & $\overline{20}$ & $\overline{29}$ & & - & $\underline{83}$ & - & - & - & - & - & - & - & - & & - & - & $\underline{75}$ & - & - & - & - & 25 & - \\
\hline $\begin{array}{l}\text { Conostegia inusitata }(\mathbf{T}) \\
\text { Alchorpe olandusa }\end{array}$ & : & 20 & - & $\underline{43}$ & - & it & - & - & - & - & - & - & - & - & $\frac{38}{-}$ & $\frac{40}{50}$ & -20 & $\underline{75}$ & - & - & - & - & - & - \\
\hline Palicourea amethystine (S) & - & - & $\underline{\underline{45}}$ & - & - & 1 & - & 60 & $=$ & - & : & 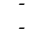 & $=$ & $=$ & $\underline{13}$ & $\frac{30}{-}$ & 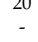 & - & 67 & 50 & $\begin{array}{l}17 \\
40 \\
\end{array}$ & $\because$ & - & $=$ \\
\hline Myrsine coriacea (T) & - & - & - & - & - & - & - & - & - & $\underline{60}$ & - & $\underline{14}$ & - & - & $\underline{I-1}$ & - & - & $\underline{75}$ & $\frac{5}{33}$ & $\frac{50}{83}$ & $\underline{-}$ & - & - & - \\
\hline Morella pubescens $(\mathrm{T})$ & - & - & - & $\underline{14}$ & - & - & - & - & - & - & - & 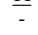 & - & - & 50 & - & - & - & $\frac{53}{33}$ & $\frac{50}{33}$ & 60 & - & & - \\
\hline Cyathea caracasana (T) & - & - & - & $=$ & - & $\underline{33}$ & - & - & - & - & - & - & - & - & $=$ & - & - & - & $\underline{33}$ & $\frac{\overline{83}}{2}$ & $\frac{50}{20}$ & - & 25 & - \\
\hline Munnozia hastifolia (S) & - & - & - & - & - & - & - & - & - & - & - & - & - & - & 50 & 20 & - & - & $\underline{33}$ & $\frac{5}{17}$ & - & - & 25 & - \\
\hline Nephrolepis cordifolia (H) & - & - & 29 & - & - & $\underline{33}$ & - & - & - & - & - & - & - & - & & $\underline{60}$ & - & - & & 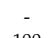 & - & - & 50 & \\
\hline Heliocarpus americanus (T) & - & - & - & - & - & $\frac{67}{67}$ & - & - & - & - & - & - & - & - & 13 & - & - & - & - & $\frac{100}{17}$ & - & $\frac{100}{100}$ & $\frac{25}{25}$ & - \\
\hline Cinchona pubescens (T) & - & - & - & - & - & $\underline{67}$ & $\therefore$ & - & - & - & - & - & - & - & $\underline{50}$ & - & - & $=$ & - & $\overline{17}$ & - & $\underline{100}$ & - & \\
\hline Ipomoea sp. (C) & - & 20 & - & - & - & $=$ & $\underline{100}$ & - & - & - & - & - & - & - & 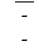 & - & - & 25 & 67 & & - & & - & - \\
\hline Vismia tomentosa $(\mathbf{T})$ & - & - & $\frac{71}{-}$ & 14 & $\therefore$ & - & - & : & - & - & - & - & - & - & - & - & - & - & $=$ & $\underline{67}$ & - & $\therefore$ & $-{ }_{25}$ & : \\
\hline Smilax domingensis (C) & 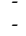 & - & - & - & $\underline{100}$ & 50 & - & : & $=$ & - & - & - & - & - & - & - & - & 50 & $\because$ & : & - & $\frac{100}{100}$ & - & - \\
\hline Blechnum cordatum (H) & - & - & - & - & - & - & - & - & - & - & - & - & - & - & 13 & - & - & $\underline{-}$ & 33 & - & 40 & & - & - \\
\hline Disterigma alaternoides (SS) & - & - & & - & - & - & - & - & - & - & - & - & - & - & 13 & - & - & - & $\frac{5}{33}$ & - & 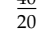 & - & - & - \\
\hline Schefflera acuminata $(\mathrm{T})$ & - & - & - & - & & - & - & - & - & & - & - & - & - & $\underline{38}$ & - & & - & $\underline{33}$ & $\underline{50}$ & 20 & - & - & - \\
\hline Ochroma pyramidale (T) & - & - & - & - & - & - & - & - & - & - & - & - & - & - & - & $\underline{40}$ & - & - & - & $=$ & - & $\underline{100}$ & $\underline{100}$ & - \\
\hline Festuca sp. (H) & 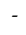 & - & - & - & $\underline{67}$ & - & - & - & - & - & $\underline{50}$ & & - & & - & & - & - & - & - & - & $\overline{-}$ & - & 6 \\
\hline $\begin{array}{l}\text { Dioscorea altissima }(\mathbf{C}) \\
\text { Polystichum montevidense } \mathbf{( H )}\end{array}$ & - & 40 & 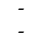 & : & - & - & - & $\therefore$ & $\overline{-}$ & 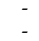 & : & 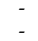 & $\because$ & 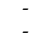 & 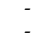 & $\frac{80}{-}$ & 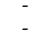 & - & $\overline{-}$ & 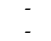 & $\overline{40}$ & 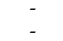 & 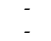 & $\frac{60}{-}$ \\
\hline
\end{tabular}

Values in cells are percentage frequencies. Underlined numbers indicate species with a frequency percentage $>30 \%$ and a phi measure $>0.2$. Only the most frequent and characteristic species are shown. The letters in brackets near the species are their life forms: $\mathrm{T}=$ Tree, $\mathrm{S}=$ Shrub, $\mathrm{SS}=$ Subshrub, $\mathrm{C}=\mathrm{Climber}, \mathrm{Ep}=\mathrm{Epiphyte}, \mathrm{H}=\mathrm{Herb}$. The colored squares are diagnostic species: Brown = Polylepidetea tarapacano-besseri, red = Pruno rigidae-Oreopanacetea floribundi, grey = Clematido peruvianae-Baccharitetea latifoliae, blue = Alnetalia acuminatae, Alnetea acuminatae, orange = Serpocaulo dasypleuronis-Alchorneion latifoliae, pink = Pteridi creticae-Cyatheion caracasanae, green: Sanchezio oblongae-Hedyosmion racemosi. Localities. $1-$ Ollachea, Puno (author data). 2-Below Ollachea, Camatani, Puno (author data). 3-San Isidro bridge, San Gabán, Puno (author data). 4-Payachaca bridge, below Ollachea, Puno (author data). Puno (author data). 2-Below Ollachea, Camatani, Puno (author data). 3-San Isidro bridge, San Gabán, Puno (author data). 4-Payachaca bridge, below Ollachea, Puno (author data). Cajamarca [18]. 10-Cachil and San Miguel, Cajamarca; Cascas, La Libertad [18]. 11—Contumazá, road down to Guzmango, Cajamarca [18]. 12-Morocha, Bellavista and Hualgayoc, Cajamarca [18]. 13-Cachil, Cajamarca [18]. 14-Jenaro Herrera, Loreto [64]. 15-San Pedro de la Capilla, Cajamarca (author data). 16-Gocta, Chachapoyas, Amazonas (author data). 17-Ocol, Chachapoyas, Amazonas (author data). 18-Ocol, Chachapoyas, Amazonas (author data). 19—Satipo, Junín (author data). 20-Satipo, Junín (author data). 21-Below Carpish, Huánuco (author data). 22-Below Carpish, Huánuco (author data). 23-Tingo María, Huánuco (author data). 24—Alpahuayo-Mishana, Iquitos, Loreto [65]. 
Table A2. Holotypes of the new associations described.

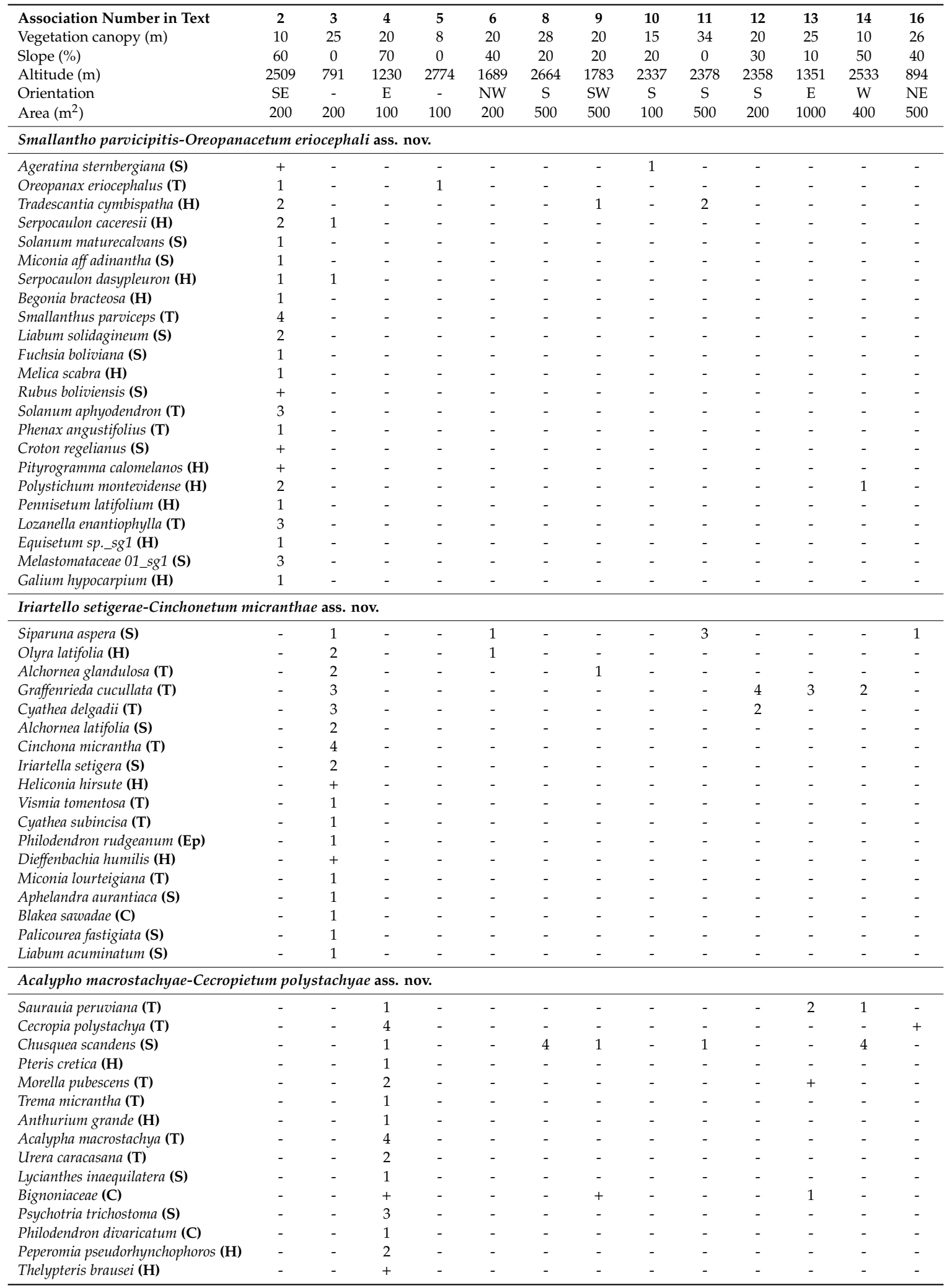


Table A2. Cont.

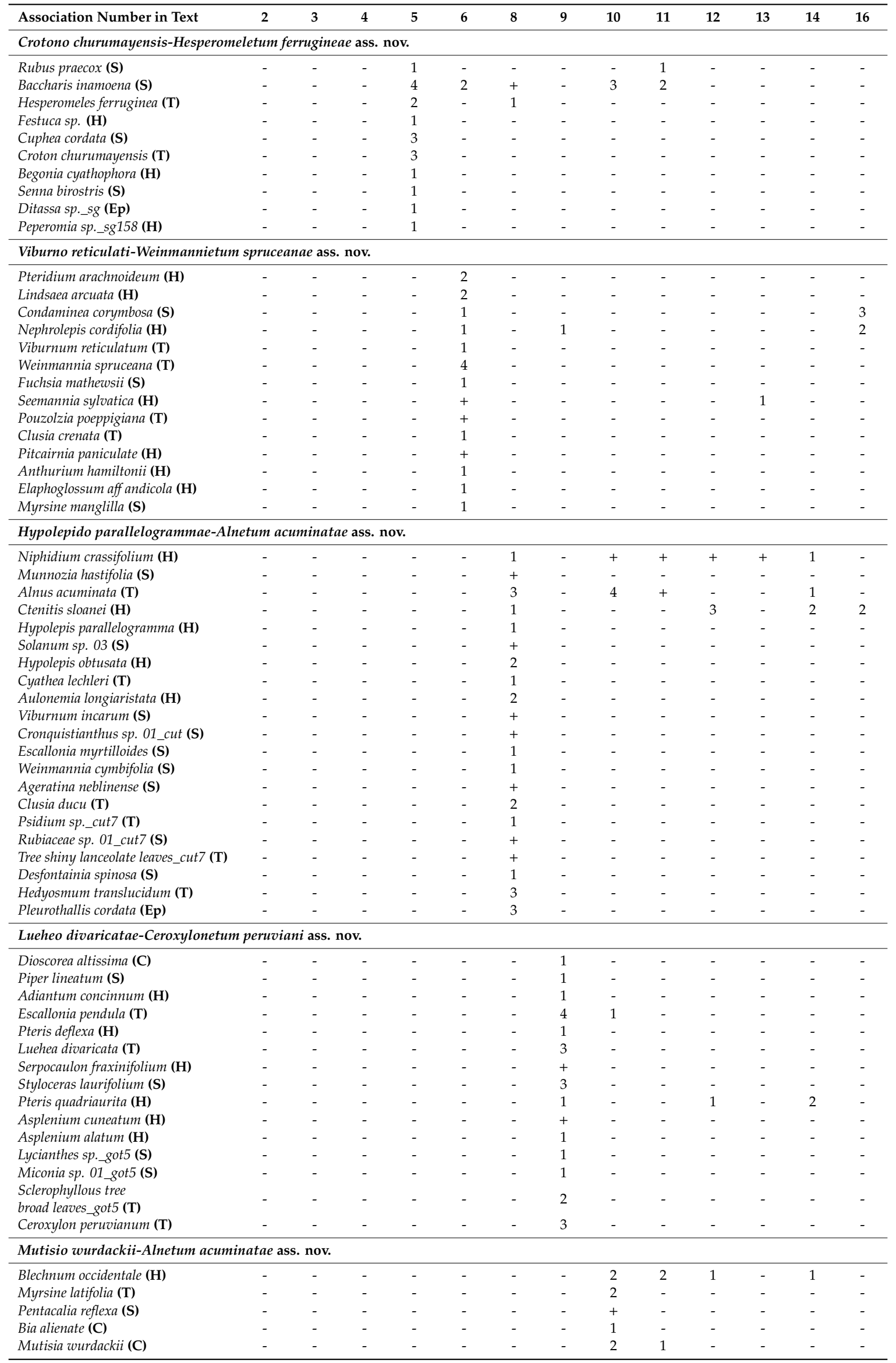


Table A2. Cont.

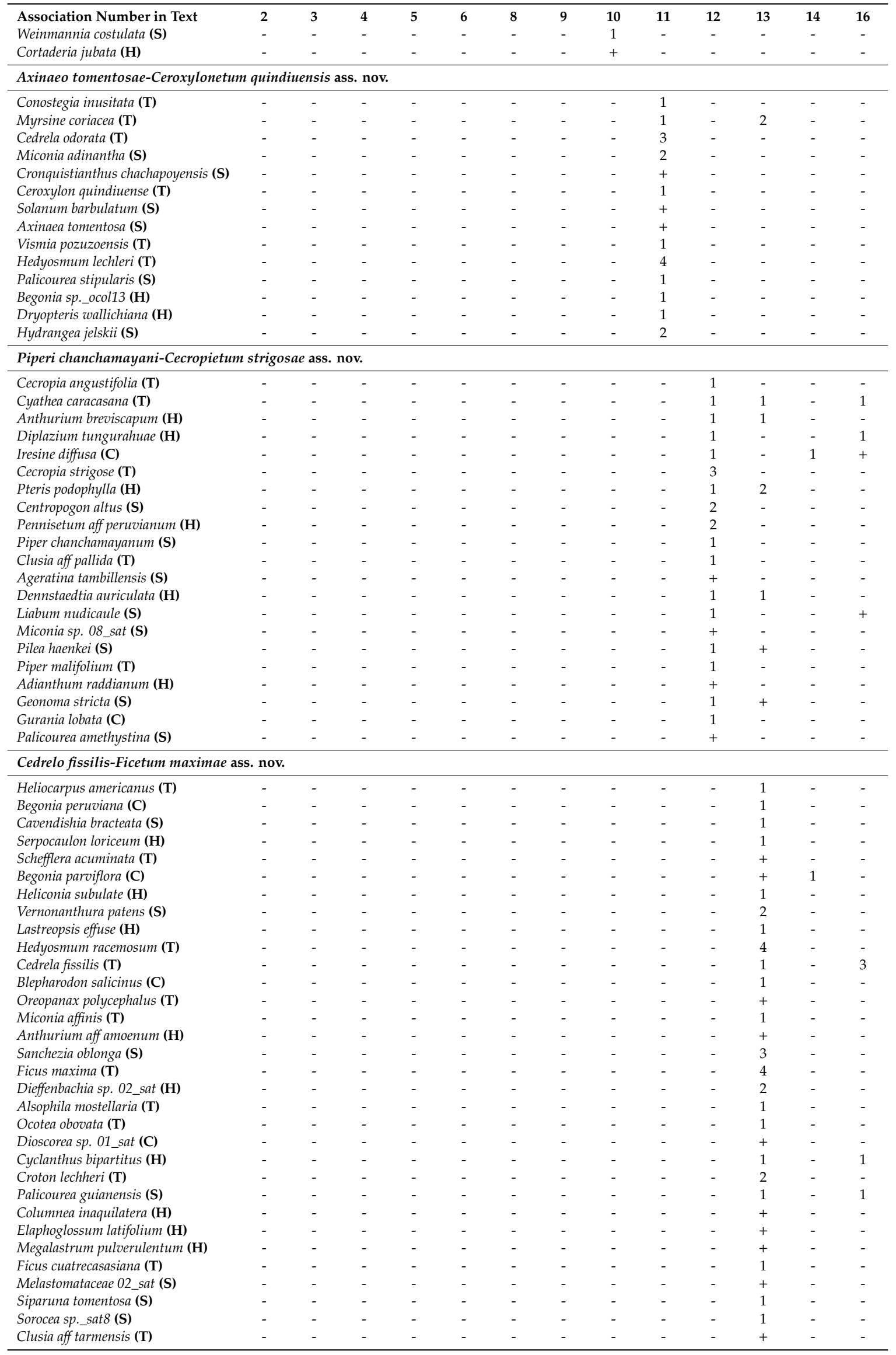


Table A2. Cont.

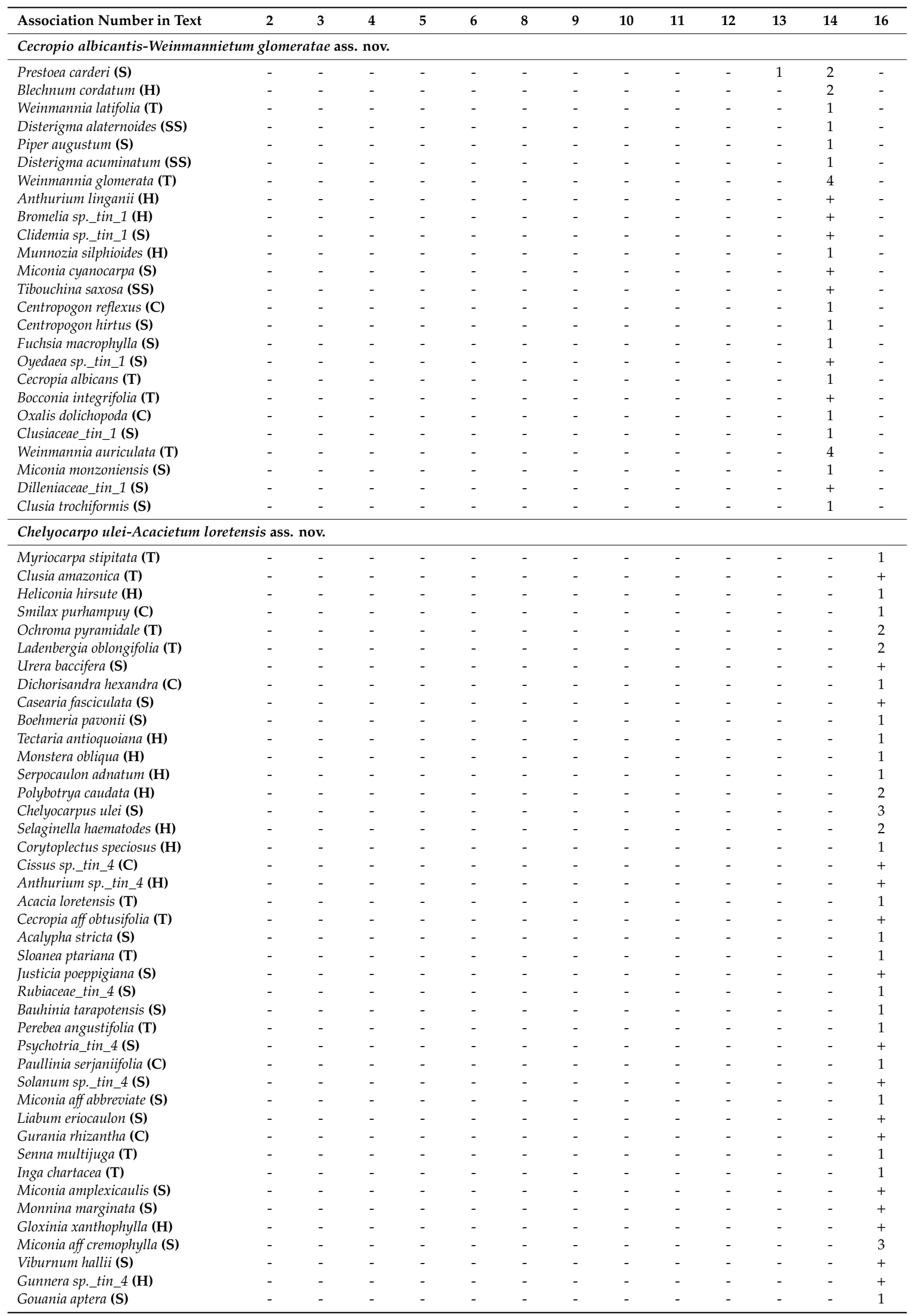


Table A2. Cont.

\begin{tabular}{|c|c|c|c|c|c|c|c|c|c|c|c|c|c|}
\hline Association Number in Text & 2 & 3 & 4 & 5 & 6 & 8 & 9 & 10 & 11 & 12 & 13 & 14 & 16 \\
\hline Ficus americana $\mathbf{( T )}$ & 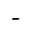 & 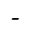 & - & - & 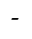 & - & - & - & - & - & - & - & 1 \\
\hline Gonzalagunia bunchosioides (S) & - & - & - & - & - & - & - & - & - & - & - & - & 1 \\
\hline \multicolumn{14}{|c|}{ 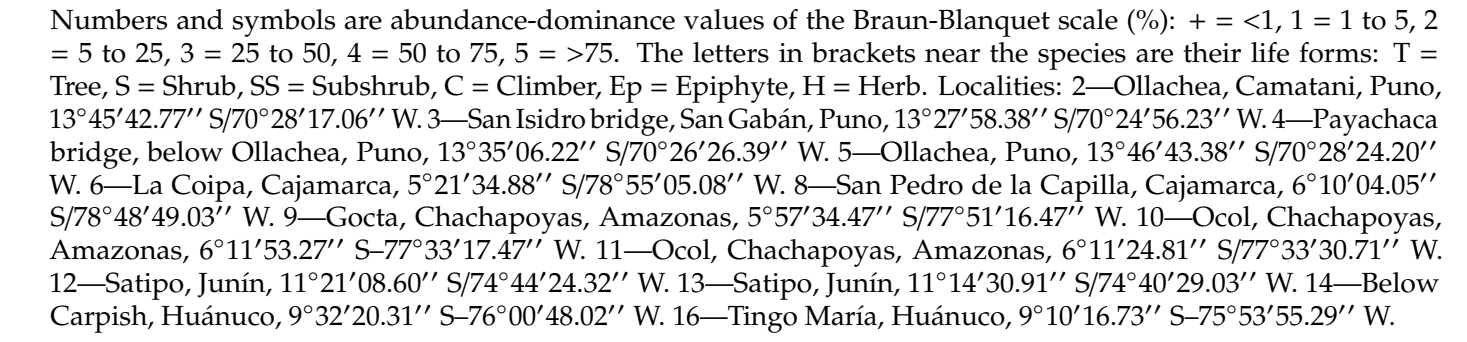 } \\
\hline
\end{tabular}

\section{References}

1. Sclultz, J. The Ecozones of the World. In The Ecological Divisions of the Geosphere; Springer: Berlin, Germany, 1995.

2. Galán de Mera, A.; Vicente Orellana, J.A. Cronosequences of vegetation-A bioclimatic theory for interpreting the patterns of relic vegetation types. Phytocoenologia 2007, 37, 471-494. [CrossRef]

3. Gentry, A.H. Patterns of diversity and floristic composition in neotropical montane forests. In Biodiversity and Conservation of Neotropical Montane Forests; Churchill, S.P., Balslev, H., Forero, E., Luteyn, J.L., Eds.; The New York Botanical Garden: New York, NY, USA, 1995; pp. 103-126.

4. Distler, T.; Jørgensen, P.M.; Graham, A.; Davidse, G.; Jiménez, I. Determinants and prediction of broad-scale plant richness across the western Neotropics. Ann. Missouri Bot. Gard. 2009, 96, 470-491. [CrossRef]

5. Cabrera, A.L.; Willink, A. Biogeografía de América Latina; Organización de Estados Americanos: Washington, DC, USA, 1980.

6. Seibert, P. Farbatlas Südamerika. Landschaften und Vegetation; Ulmer: Stuttgart, Germany, 1996.

7. Rangel, O.; Lowy, P.D.; Aguilar, M.; Garzón, A. Tipos de vegetación en Colombia. Colomb. Divers. Biótica 1997, 2, 89-381.

8. Weberbauer, A. The phytogeography of the Peruvian Andes. In Flora of Peru; MacBride, J.F., Ed.; Field Museum of Natural History (Botany): Chicago, IL, USA, 1936; Volume 13, pp. 13-81.

9. Weberbauer, A. El Mundo Vegetal de los Andes Peruanos; Ministerio de Agricultura: Lima, Perú, 1945.

10. Hueck, K. Die Wälder Südamerikas. Ökologie, Zusammensetzung und Wirtschaftliche Bedeutung; Gustav Fischer: Sttutgart, Germany, 1966.

11. Hueck, K.; Seibert, P. Vegetationskarte von Südamerika; Gustav Fischer: Stuttgart, Germany, 1981.

12. Egg, B.A.; Vargas, M.C. Ecología del Perú; Bruño: Lima, Perú, 2004.

13. Vázquez, R.; Rojas, R.; Monteagudo, A.; Meza, K.; Van der Werff, H.; Ortiz-Gentry, R.; Catchpole, D. Flora vascular de la selva central del Perú: Una aproximación de la composición florística de tres Áreas Naturales Protegidas. Arnaldoa 2005, 12, 112-125.

14. Young, K.R.; León, B.; Jørgensen, P.M.; Ulloa, U.C. Tropical and subtropical landscapes of the andes. In The Physical Geography of South America; Veblen, T.T., Young, K.R., Orme, A.R., Eds.; Oxford University Press: New York, NY, USA, 2007; pp. 200-216.

15. Malizia, A.; Blundo, C.; Carilla, J.; Osinaga, O.; Cuesta, F.; Duque, A.; Aguirre, N.; Aguirre, Z.; Ataroff, M.; Baez, S.; et al. Elevation and latitude drives structure and tree species composition in Andean forests: Results from a large-scale plot network. PLoS ONE 2020, 15, e0231553. [CrossRef]

16. Dodson, C.H.; Gentry, A.H. Biological extinction in Western Ecuador. Ann. Missouri Bot. Gard. 1991, 78, 273-295. [CrossRef]

17. Sánchez Vega, I.; Grados Quezada, N. Estudio florístico y ambiental del bosque relicto Mijal en la Provincia de Morropón, Piura. Arnaldoa 2007, 14, 259-268.

18. Galán de Mera, A.; Sánchez Vega, I.; Montoya Quino, J.; Linares Perea, E.; Campos de la Cruz, J.; Vicente Orellana, J.A. La vegetación del Norte del Perú: De los bosques a la jalca en Cajamarca. Acta Bot. Malac. 2015, 40, 157-190. [CrossRef]

19. Critical Ecosystem. Hotspot de Biodiversidad de los Andes Tropicales. Available online: andestropicales.net (accessed on 8 July 2020). 
20. Vásquez, P.; Tovar, A.; Young, C.; Soto, A.; Tovar, C.; Saito, J.; Regal, F.; Rivera, G.; Veliz, C.; Gushiken, E.; et al. Planificación Para la Conservación Eco-Regional de las Yungas Peruanas: Conservando la Diversidad Natural de la Selva Alta del Perú; Universidad Nacional Agraria La Molina-The Natural Conservancy: Lima, Perú, 2008.

21. Hoorn, C.F.P.; Wesselingh, H.; ter Steege, M.A.; Bermudez, A.; Mora, J.; Sevink, I.; Sanmartin, I.; SanchezMeseguer, A.; Anderson, C.L.; Figueiredo, J.P.; et al. Amazonia through time: Andean uplift climate change. landscape evolution and biodiversity. Science 2010, 30, 927-931. [CrossRef]

22. Rowley, D.B.; Garzione, C.N. Stable isotope-based palaeoaltimetry. Annu. Rev. Earth Planet. Sci. 2007, 35, 463-508. [CrossRef]

23. Garzione, C.N.; Hoke, G.D.; Libarkin, J.C.; Withers, S.; MacFadden, B.; Eiler, J.; Ghosh, P.; Mulch, A. Rise of the Andes. Science 2008, 320, 1304-1307. [CrossRef]

24. Ibaraki, M. Closing of the Central American Seaway and Neogene coastal upwelling along the Pacific coast of South America. Tectophysics 1997, 281, 99-104. [CrossRef]

25. Gentry, A.H. Neotropical floristic diversity: Phytogeographical connections between Central and South America, pleistocene climatic fluctuations, or an accident of the Andean orogeny. Ann. Missouri Bot. Gard. 1982, 69, 557-593. [CrossRef]

26. Walter, H. Zonas de Vegetación y Clima; Omega: Barcelona, Spain, 1997.

27. Rivas-Martínez, S.; Navarro, G.; Penas, A.; Costa, M. Biogeographic map of South America. A preliminary survey. Int. J. Geobot. Res. 2011, 1, 21-40. [CrossRef]

28. Takhtajan, A. Floristic Regions of the World; University of California Press: Berkeley, CA, USA, 1986.

29. Morrone, J.J. Biogeografía de América Latina y el Caribe; M \& T-Manuales \& Tesis SEA: Zaragoza, Spain, 2001.

30. Braun-Blanquet, J. Plant Sociology. The Study of Plant Communities; Koeltz Scientific Books: Koenigstein, Germany, 1932.

31. Mucina, L.; Rutherford, M.C. The Vegetation of South Africa, Lesotho and Swaziland; South African National Biodiversity Institute: Pretoria, South Africa, 2006.

32. Walker, D.A.; Kuss, P.; Epstein, H.E.; Kade, A.N.; Vonlanthen, C.M.; Raynolds, M.K.; Daniëls, F.J.A. Vegetation of zonal patterned-ground ecosystems along the North America Arctic bioclimatic gradient. Appl. Veg. Sci. 2011, 14, 440-463. [CrossRef]

33. Peinado, M.; Ocaña-Peinado, F.M.; Aguirre, J.L.; Delgadillo, J.; Macías, M.A.; Díaz-Santiago, G. A phytosociological and phytogeographical survey of the coastal vegetation of western North America: Beach and dune vegetation from Baja California to Alaska. Appl. Veg. Sci. 2011, 14, 464-484. [CrossRef]

34. Li, C.F.; Zelený, D.; Chytrý, M.; Chen, M.Y.; Chen, T.Y.; Chiou, C.R.; Hsia, Y.J.; Liu, H.Y.; Yang, S.Z.; Yeh, C.L.; et al. Chamaecyparis montane cloud forest in Taiwan: Ecology and vegetation classification. Ecol. Res. 2015, 30, 771-791. [CrossRef]

35. Rodríguez, E.E.; Aceñolaza, P.G.; Linares Perea, E.; Galán de Mera, A. A phytosociological analysis of Butia yatay (Arecaceae) palm groves and gallery forests in Entre Rios, Argentina. Aust. J. Bot. 2017, 65, 183-202. [CrossRef]

36. Ortiz, C.A.; Musarella, C.M.; Gomes, P.C.J.; Canas, Q.R.; Fuentes, P.J.C.; Cano, E. Phytosociological study, diversity and conservation status of the cloud forest in the Dominican Republic. Plants 2020, 9, 741. [CrossRef]

37. Vareschi, V. Sobre las superficies de asimilación de sociedades vegetales en cordilleras tropicales y extratropicales. Bol. Soc. Venez. Ci. Nat. 1953, 79, 121-173.

38. Meier, W. Flora und Vegetation des Ávila-Nationalparks (Venezuela, Küstenkordillera) unter besonderer Berücksichtigung der Nebelwaldstufe. Diss. Bot. 1998, 296, 1-485.

39. Cuello, N.L.; Cleef, A.M. The forest vegetation of Ramal de Guaramacal in the Venezuelan Andes. Phytocoenologia 2009, 39, 109-156. [CrossRef]

40. Cuatrecasas, J. Observaciones geobotánicas en Colombia. Trab. Mus. Nac. Ci. Nat., Ser. Bot. 1934, $27,5-144$.

41. Franco, P.; Rangel, O.; Lozano, G. Estudios ecológicos en la Cordillera Oriental, II. Las comunidades vegetales de los alrededores de la laguna de Chingaza (Cundinamarca). Caldasia 1986, 15, 71-75. [CrossRef]

42. Cleef, A.M.; Rangel, J.O.; Salamanca, S. The Andean rainforest of the Parque Los Nevados Transect, Cordillera Central, Colombia. Estud. Ecosistemas Tropandinos 2003, 5, 79-141.

43. Rangel, O.; Cleef, A.M.; Salamanca, S.; Ariza, C. La vegetación de los bosques y selvas del Tatamá. Estud. Ecosistemas Tropandinos 2005, 6, 459-643.

44. Rangel, O.; Cleef, A.M.; Arellano, H. La vegetación de los bosques y selvas del transecto Sumapaz. Estud. Ecosistemas Tropandinos 2008, 7, 695-797. 
45. Lauer, W.; Rafiqpoor, M.D.; Theisen, I. Physiogeographie, Vegetation und Syntaxonomie der Flora des Páramo de Papallacta (Ostkordillere Ecuador); Franz Steiner: Stuttgart, Germany, 2001.

46. Bussmann, R.W. The vegetation of Reserva Biológica San Francisco, Zamora-Chinchipe, Southern Ecuador-A phytosociological synthesis. Lyonia 2003, 3, 145-254.

47. Navarro, G.; Maldonado, M. Geografía Ecológica de Bolivia. Vegetación y Ambientes Acuáticos; Fundación Simón I. Patiño: Santa Cruz, Bolivia, 2002.

48. Aceñolaza, P.G. Fitosociología de bosques de aliso (Alnus acuminata HBK subsp. acuminata) en la sierra de San Javier, Tucumán, Argentina. Doc. Phytosoc. 1996, 16, 505-516.

49. Giusti, L.; Slanis, A.; Aceñolaza, P. Fitosociología de los bosques de aliso (Alnus acuminata H.B.K. ssp. acuminata) de Tucumán (Argentina). Lilloa 1997, 38, 93-120.

50. Entrocassi, G.S.; Gavilán, R.G.; Sánchez-Mata, D. Subtropical Mountain Forests of Las Yungas: Vegetation and Bioclimate; Springer: Cham, Switzerland, 2020.

51. Galán de Mera, A.; Vicente Orellana, J.A.; Lucas García, J.A.; Probanza Lobo, A. Phytogeographical sectoring of the Peruvian coast. Glob. Ecol. Biogeogr. Lett. 1997, 6, 349-367. [CrossRef]

52. Galán de Mera, A.; Linares Perea, E.; Campos de la Cruz, J.; Vicente Orellana, J.A. Interpretación fitosociológica de las lomas del desierto peruano. Rev. Biol. Trop. 2011, 59, 809-828. [CrossRef] [PubMed]

53. Galán de Mera, A.; Sánchez Vega, I.; Linares Perea, E.; Campos, J.; Montoya, J.; Vicente Orellana, J.A. A phytosociological analysis and synopsis of the dry woodlands and succulent vegetation of the Peruvian Andes. An. Acad. Bras. Cienc. 2016, 88, 689-703. [CrossRef] [PubMed]

54. Galán de Mera, A.; Méndez, E.; Linares Perea, E.; Campos de la Cruz, J.; Vicente Orellana, J.A. Las comunidades vegetales relacionadas con los procesos criogénicos en los Andes peruanos. Phytocoenologia 2014, 44, 121-161. [CrossRef]

55. Reynel, C.; Pennington, R.T.; Särkinen, T. Cómo se Formó la Diversidad Ecológica del Perú; Fundación para el Desarrollo Agrario: Lima, Perú, 2013.

56. Beaudet, G.; Gabert, P.; Philip, H.; Usselmann, P. Geomorfología de los Andes Centrales Sudamericanos (Un Corte Entre Perú Meridional y Bolivia Central); CNRS-Sociedad Geográfica de Lima: Lima, Perú, 2012.

57. Izco, J. The biological reserve of San Francisco (Ecuador): Revision of the syntaxonomy and nomenclature of the vegetation. Lazaroa 2013, 34, 257-266. [CrossRef]

58. Galán de Mera, A.; Rosa, M.V.; Cáceres, C. Una aproximación sintaxonómica sobre la vegetación del Perú. Clases, órdenes y alianzas. Acta Bot. Malac. 2002, 27, 75-103. [CrossRef]

59. Galán de Mera, A. Clasificación fitosociológica de la vegetación del Caribe y América del Sur. Arnaldoa 2005, 12, 86-111.

60. Fernández Terrazas, E. Estudio fitosociológico de los bosques de Kewiña (Polylepis spp., Rosaceae) en la Cordillera de Cochabamba. Rev. Bol. Ecol. 1997, 2, 49-65.

61. Hensen, I. Die vegetation von polylepis-wäldern der ostkordillere boliviens. Phytocoenologia 1995, 25, $235-277$. [CrossRef]

62. Mendoza, W.; Cano, A. El Género Polylepis en el Perú. Taxonomía, Morfología y Distribución; Editorial Académica Española: Saarbrücken, Germany, 2012.

63. Seibert, P.; Menhofer, X. Die vegetation des wohngebietes der kallawaya und des hochlandes von Ulla-Ulla in den bolivianischen Anden. I. Phytocoenologia 1991, 20, 145-276. [CrossRef]

64. Galán de Mera, A. Relación entre los suelos y la vegetación del Perú. Arnaldoa 1996, 4, 87-94.

65. Galán de Mera, A. Una aproximación fitosociológica sobre los varillales húmedos de la Amazonía peruana. Stud. Bot. Univ. Salamanca 2001, 20, 125-133.

66. Rangel, O.; Aguilar, M.; Sánchez, H.; Lowy, P.; Garzón, A.; Sánchez, L.A. Región de la Amazonía. Colomb. Divers. Biótica 1987, 1, 82-103.

67. Ramia, M. Tipos de sabanas en los llanos de venezuela. Bol. Soc. Venez. Ci. Nat. 1967, 27, $264-288$.

68. Rangel, O.; Minorta-Cely, V. Tipos de vegetación de la Oriniquía colombiana. Colomb. Divers. Biótica 2018, 14, 533-612.

69. QGIS Geographic Information System. Open Source Geospatial Foundation Project. Available online: https://www.qgis.org/ (accessed on 18 July 2019).

70. Instituto de Geología y Minería. Mapa Geológico del Perú. Escala 1: 1.000.000; Ministerio de Energía y Minas: Lima, Perú, 1975. 
71. Rivas-Martınez, S. Worldwide Bioclimatic Classification System. Available online: http://www. globalbioclimatics.org (accessed on 15 July 2018).

72. Schwarz, T. Climate-Data.org. Available online: http://es.climate-data.org/ (accessed on 18 July 2018).

73. Galán deMera, A.; Campos de la Cruz, J.; Linares-Perea, E.; Montoya-Quino, J.; Trujillo-Vera, C.; Villasante-Benavides, F.; Vicente-Orellana, J.A. Un ensayo sobre bioclimatología, vegetación y antropología en el Perú. Chloris Chil. 2017, 20, 2.

74. Dengler, J.; Chitrý, M.; Ewald, J. Phytosociology. In Encyclopedia of Ecology; Jørgensen, S.E., Fath, B.D., Eds.; Elsevier: Oxford, UK, 2008; pp. 2767-2779.

75. Phillips, O.; Miller, J.S. Global Patterns of Plant Diversity: Alwyn H. Gentry's Forests Transect Data Set; Missouri Botanical Garden: St. Louis, MO, USA, 2002.

76. Macbride, J.F. Flora of Peru; Field Museum of Natural History: Chicago, IL, USA, 1936-1995.

77. Tryon, R. The ferns of Peru, Polypodiaceae (Dennstaedtieae to Oleandreae). Contrib. Gray Herb. 1964, 194, 3-253.

78. Gentry, A.H. A Field Guide to the Families and Genera of Woody Plants of Northwest South America (Colombia, Ecuador, Peru) with Supplementary Notes on Herbaceous Taxa; Conservation International: Washington, DC, USA, 1993.

79. Tryon, R.M.; Stolze, R.G. Pteridophyta of Peru Part I. 1. Ophioglossaceae-12. Cyatheaceae. Fieldiana Bot. 1989, 20, 1-145. [CrossRef]

80. Tryon, R.M.; Stolze, R.G. Pteridophyta of Peru Part IV. 17. Dryopteridaceae. Fieldiana Bot. 1991, 27, 1-176.

81. Tryon, R.M.; Stolze, R.G. Pteridophyta of Peru Part III. 16. Thelypteridaceae. Fieldiana Bot. 1992, $29,1-80$. [CrossRef]

82. Tryon, R.M.; Stolze, R.G. Pteridophyta of Peru Part V. 18. Aspleniaceae-21. Polypodiaceae. Fieldiana Bot. 1993, 32, 1-190. [CrossRef]

83. Tryon, R.M.; Stolze, R.G. Pteridophyta of Peru Part VI. 22. Marsileaceae-28. Isoetaceae. Fieldiana Bot. 1994, 34, 1-123. [CrossRef]

84. Tovar, O. Las Gramíneas (Poaceae) del Perú. Ruizia 1993, 13, 9-480.

85. Henderson, A.; Galeano, G.; Bernal, R. Field Guide to the Palms of the Americas; Princeton University Press: Princeton, NJ, USA, 1995.

86. Brako, L.; Zarucchi, J.L. Catalogue of the Flowering Plants and Gymnosperms of Peru; Missouri Botanical Garden: St. Louis, MO, USA, 1993.

87. Beltrán, H.; Salinas, I. Flora vascular y vegetación de los Bosques Montanos Húmedos de Carpish (Huánuco-Perú). Arnaldoa 2010, 17, 107-130.

88. Monteagudo Mendoza, A.L.; Huamán Guerrero, M. Catálogo de los árboles y afines de la Selva Central del Perú. Arnaldoa 2010, 17, 203-242.

89. Thiers, B.M. Index Herbariorum. Available online: http://sweetgum.nybg.org/science/ih/ (accessed on 5 December 2016).

90. The Plant List. A Working List of All Plant Species, Versión 1.1. Available online: http://www.theplantlist.org/ (accessed on 19 June 2020).

91. Sørensen, T. A method of establishing groups of equal amplitude in plant sociology based on similarity of species and its application to analyses of the vegetation on Danish commons. Kongel. Danske Vidensk. Selsk. 1957, 5, 1-34.

92. Tichý, L. JUICE, software for vegetation classification. J. Veg. Sci. 2002, 13, 451-453. [CrossRef]

93. Hammer, Ø. PAST_Paleontological Statistics Version 4.03; University of Oslo: Oslo, Norway, 2020.

94. Chytrý, M.; Tichý, L.; Holt, J.; Botta-Dukat, Z. Determination of diagnostic species with statistical fidelity measures. J. Veg. Sci. 2002, 13, 79-90. [CrossRef]

95. Tichý, L.; Chytrý, M. Statistical determination of diagnostic species for site groups of unequal size. J. Veg. Sci. 2006, 17, 809-818. [CrossRef]

96. Theurillat, J.P.; Willner, W.; Fernández-González, F.; Bültmann, H.; Čarni, A.; Gigante, D.; Mucina, L.; Weber, H. International code of phytosociological nomenclature. Appl. Veg. Sci. 2020. [CrossRef]

Publisher's Note: MDPI stays neutral with regard to jurisdictional claims in published maps and institutional affiliations. 